\title{
FLOWERS AND PLANTS FOR 9 DESIGNERS \& 9 AND SCHOOLS
}

HENRY IRVING AND EDWARD F.STRANGE . 

Digitized by the Internet Archive in 2016 


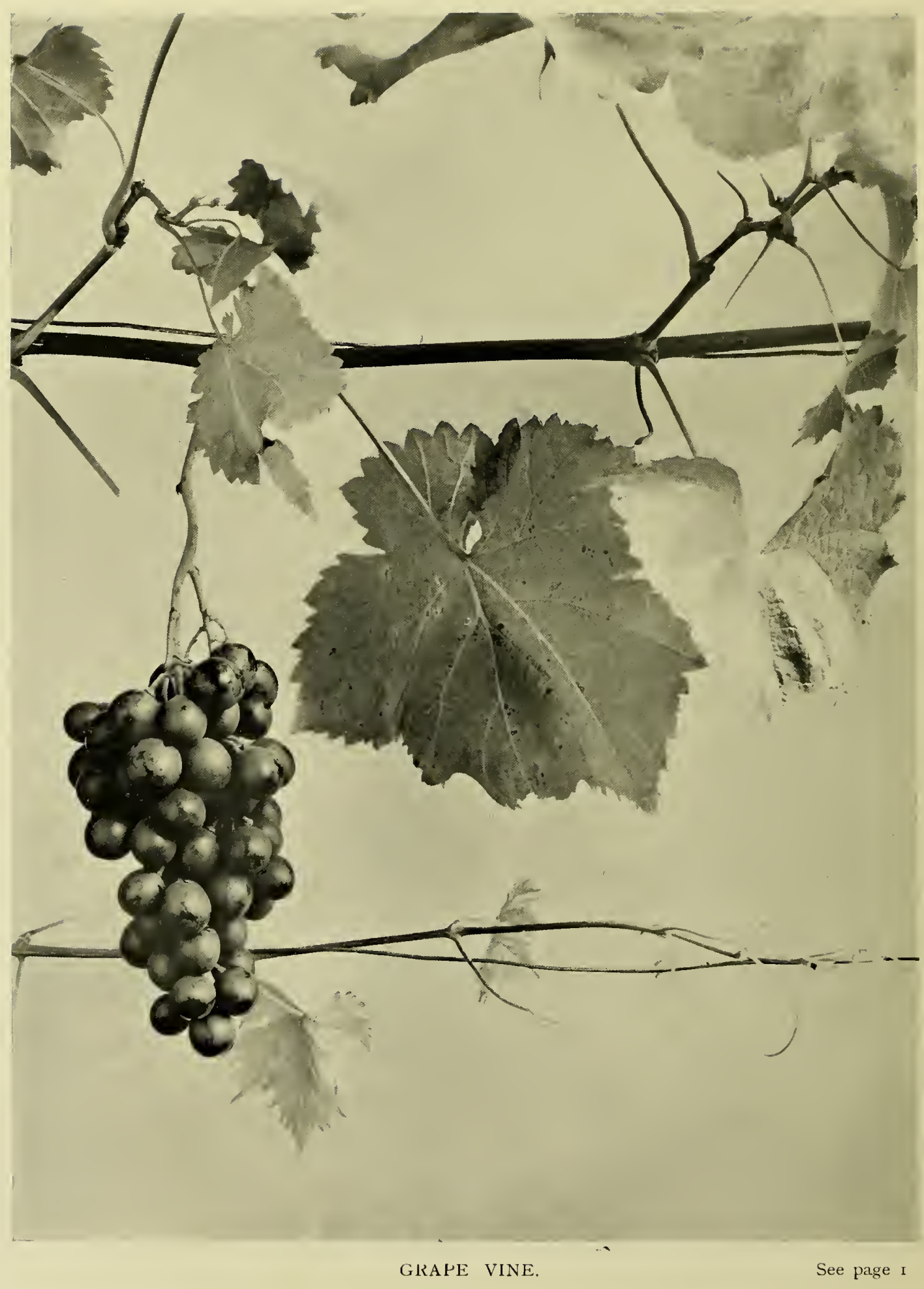




\title{
FLOWERS AND PLANTS \\ FOR \\ DESIGNERS AND SCHOOLS
}

\author{
PHOTOGRAPHED FROM NATURE \\ BY \\ HENRY IRVING
}

\author{
WITH TEXT AND NOTES \\ BY \\ EDWARD F. STRANGE \\ AUTHOR OF "ALPHABETS," ETC.
}

HODDER AND STOUGHTON

LONDON MCMVII 


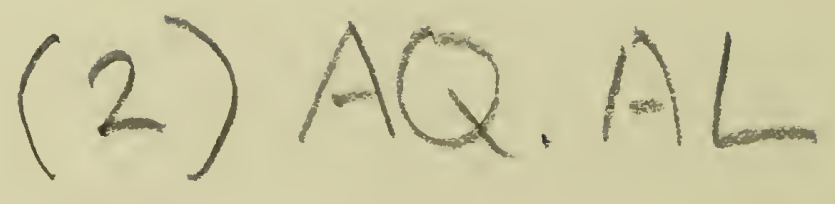

"I hold, moreover, that there is a phytognomy, or physiognomy not only of men, but of plants and vegetables."-Sir Thomas Browne. Religion Medici.

Well come Library

far the History and tutcertarding Q intine line 
To the Countess of Arran

THIS BOOK IS DEDICATED. 



\section{I.- - The Study of the Plant}

THE student who desires to master the mysteries of plantform, and turn them to account in the practice of design, will find no royal road leading to the attainment of his wish. It is necessary at the outset that he should be equipped with two at least of the essentials of any artistic career: the power of seeing, and of recording faithfully, and with sympathy, that which is seen. These things can be learned-the higher qualities of invention and imagination are gifts from Nature. They may be brilliantly conspicuous; in which case they are none the worse for formal exercise and healthy discipline. They may, and more often, perhaps, do, lie hidden and unsuspected beneath those thick coverings of conventionality, which our civilization and system of education so often succeed in imposing on the character of the individual; and then, are only to be developed by pain and strife and patient labour. Far more people are born with genius than the world suspects; but for want of stimulus and encouragement and application, the talent too often lies for ever buried in its napkin. The "infinite capacity for taking pains" will not bring increase unless the seed already exists. But until he has thus refined and searched himself, who shall say that the student has it not?

The businesses of seeing and of drawing should go on side by side; though they are not necessarily interdependent. The first is a matter of intellectual, the other of manual training. One can conceive-rarely-of an accomplished draughtsman who sees, indeed, and yet is blind. He may have an exquisite gift of technique; and still miss all that was best worth drawing or painting. The power of selection is, however, one that can be largely augmented by careful cultivation. It is, to a great extent, born of the confidence that comes with knowledge and sedulous practice. One's mind instinctively acquires the gift of rejecting things of no importance and of dealing worthily with what deserves 
the attention. Artists and craftsmen fail by reason of selfflattery. He who would succeed should allow no one to criticize his work more severely than he himself does.

Our designer, then, must set his heart, above all things, on the acquisition of a sound technique and of a wide and catholic, yet critical faculty of observation. The former is a question of such importance as to merit some separate examination.

The purpose we have in view-the use of plant-form for the making of pattern-calls for a technical practice somewhat more restricted than that needed by a painter, in the large sense of the word. Pattern is always, of its very nature, a matter of precise outline in the making. Its broad effects are produced by judicious massing or distribution of clearly defined elements, each of which must be capable of simple reproduction, by the more or less mechanical process employed to carry it out, in the chosen fabric. For this, painting in oils is generally unsuitable : and the designer must be content often to deny himself the pleasure derived from the immeasurable subtleties of line and blended colour of which that medium is capable. The hard point of the pen, again, is almost to the same extent, to be avoided. If, for some few branches of pattern-making, it may be possible, the proper use of it can easily be acquired when needed. During the educational stage it is better let alone. Even afterwards, though there is a certain fascination in wielding a quill, results more true and more pleasant can be got with the brush-by far the best tool for design in black and white, whether in line or mass.

For the acquirement of a pure and good style of drawing, there is nothing to equal charcoal. This should be the mainstay of the designer. He must master it during his apprenticeship, learning to draw with ease and freedom and spaciousness. A lead pencil, be it never so soft, is an obstinate and unwilling implement in comparison, though it has its important place in the actual process of making finished designs; and in those valuable but ephemeral notes and studies which are always necessary. But to the student who is training himself for the craft of pattern-making-whether his aspirations lie in the direction 


\section{The Study of the Plant}

of ornament devised from plant-form or from anything else, there is one precept always to be borne in mind-to exercise himself constantly, with charcoal, in making rapid, bold, direct studies from the highest form of natural life-the human figure. A faithful observation of its infinite variety of line and subtlety of form and structure is the best and only preparation for the study of Nature in her lower phases.

Presuming the designer to have acquired the technique necessary to enable him to specialize in the study of plants and flowers, there yet remains a word to be said as to his methods therein. Of late years, a tendency has been manifest to encourage certain conventions, easy enough to produce, which, to the generous eye of faith appear as the similitudes of flowers and leaves. A blob made with a brush charged with water-colour has a remote resemblance to a petal. Half-a-dozen of them, arranged around a central dot, may be likened unto a flower. And the changing of the colours, or thickening or elongating of the blobs, are understood to give the perpetrator the right to call his productions marigolds, daisies, primroses, cornflowers or what not. This process is called brush-work, instead of, as it should be, brushplay. The trick is simple enough; and its results, to the uninstructed, are plausible and effective if the colour be kept clean. It may have an educational value of some importance to children; but the fallacy lies in its common confusion with nature study, for it is deadly poison to the would-be craftsman. $\mathrm{He}$, if he would thrive, must learn his plant by heart. He must consider the wonderful engineering by which Nature builds it up from root to blossom; its delicacy of tint; its endless play of line and gradation of contour ; the balance of leaf with leaf, and vein with vein within them; the promise of blossom that the bud holds forth; "the symmetry and proper disposition of organs;" the perfection of composition shown by a freely-grown and mature plant-each and all of these hold golden truths for - the designer. They will teach him more about his craft than all the cant of the scholiast and the jargon of the text-books. He works, it is true, with symbols, conventions. There is no realism 


\section{The Study of the Plant}

in good pattern. But to set up first a stock of conventions and then try to turn them into a semblance of natural form is pure topsy-turvydom. He must learn his Book of Nature first; and, on that sure foundation of knowledge, build the work of his life. His time will not be wasted. All that he sees will be of use. "There are," says old Sir Thomas Browne, " no grotesques in nature; not anything framed to fill up empty cantons and unnecessary spaces."

This present generation dearly loves to take short cuts and to save labour. Designers too often prefer to get their material ready-made, so to speak; and evolve their patterns by a curious process of borrowing from each other-as one might term ita habit of artistic in-breeding. The commercial silversmiths are perhaps the worst offenders, in this respect. Being a very close corporation, singularly repugnant to outside influences, they have arrived at a set of patterns which are most astonishingly devoid of character and individuality. The ornament of their choice has not even strength and flavour enough to be worthy of the term traditional; as is that of their Indian, Burmese and Siamese contemporaries. There is a grave suspicion that modern designers generally are moving in the same direction. The great and far-reaching influence exerted by the mass of Japanese pattern which has, of late, become available, may prove to have this effect. The Japanese have been found to have produced certain admirable renderings of plant-form and flowers, which were beautifully drawn and coloured and arranged; and, at once, as they stood, suitable to be adapted to the requirements of European pattern. Moreover, they have an astonishing appearance of being the results of genuine Nature study ; and the drawings, presumably of real flowers, are executed with a dexterity of brush-work that deceives the very elect. As a matter of fact, these extraordinarily clever productions are merely the result of the method described above. They are not gained by close, personal observation of Nature on the part of the artist. The Japanese painter rarely troubles himself in that way. He learns to draw a flower, as his master drew it-and with as little reference 


\section{The Study of the Plant}

to the original. The whole thing rests on a basis of dexterous manipulation of the brush; the strokes produced by which are brought, by a process of elimination and selection extending over generations, to a simple and convincing pseudo-realism. The Japanese art student in England will turn out for you, by the gross, these imitation nature studies, from flowers which thrive only at the other side of the world.

But, advisable though it is that the designer should go to Nature for his material, he must avoid attempts at rivalry of her in his patterns. He works-indeed, whether he will or not-in conventions ; and his conventions must be frankly such, and not merely those that are imposed by the medium in which he draws or paints. Nothing is in worse taste than imitation realism in design. The purpose of pattern is to supply a pleasing and interesting variety of form or colour, or both, to the fabric to which it is applied. In the large majority of cases the exigencies of the process of manufacture require that this pattern shall be symmetrically arranged in order that it may "repeat" to any extent. This alone implies a formal and non-natural arrangement of any plant-form that may be chosen ; and when one considers how unsuitable to a flat surface are drawings which represent modelling of any kind, the need for a severe convention becomes at once apparent.

Still the splendid symmetry and proportion of the natural plant must be neither profaned nor disregarded. Even in ornament-one might say, especially in ornament-the sense of rational growth and construction must be maintained, wherever the pattern is such as to allow of it. In spotting and powdering, the skill of the designer is displayed in the choice of elements derived from a single flower or leaf; and in a happy distribution of them over the surface to be decorated. But where a built-up pattern is employed, more than a mere semblance of growth must be preserved; or the eye will be offended by unfamiliar proportions. And this is the one unforgiveable sin in applied decoration of any description. To be pleasing it must be restful ; free from any disquieting tendencies which excite the attention 
The Study of the Plant

unduly and lead it away from the enjoyment of the essentials of the object decorated-of which all enrichment should only be a subordinate adjunct.

In conclusion, some broad general axioms may be shortly stated as bases on which all good decoration is built.

Firstly, the decoration must follow the construction of the object adorned, and neither obscure nor nullify it.

It must be made with the fullest regard both for the nature of the material used and for the purposes to which the decorated object is to be applied. Thus it is an offence against good taste to fill wall-papers with flowers drawn in perspective or with an imitation of relief. Flat pattern must be kept flat.

A treatment of natural form which is suitable for one purpose is not necessarily good for another. In adapting the plant to ornament, its growth and the due proportion of its parts must be borne in mind, however complete the convention. Otherwise the result will be illogical and incongruous, if not absurd.

A proper regard for fitness of the subject to the proposed use of it should be maintained.

And, finally, richness of effect is not to be obtained by overelaboration of detail. A simple but cunningly arranged pattern will bring about this result more surely than an infinity of niggling with microscopic items; for broad and telling masses and contrasts of colour, and harmonious line and form, are the foundations of all that is most splendid in the art of decoration. 


\section{II.-Plant-form in Historical Ornament}

THE use of plant-form in ornament goes back to remote antiquity. The knop and flower pattern, for instance, which is still characteristic of so many forms of Oriental art, is found on Assyrian sculptures; and good examples of it are figured in Rawlinson's Ancient Monarchies. In Egypt, this decorative detail was composed of the date-palm and its fruit, the lotus and its bird, the lotus flower and a bunch of grapes, or the papyrus head (Birdwood); and highly-conventionalized forms of these elements have persisted throughout all the subsequent artistic styles, even up to the present time. The best-known adaptations of plant-form devised by the ancient Greeks were, of course, the acanthus-so finely used in the Corinthian Order, among other architectural ornaments; and the so-called honeysuckle flower, which, however, is considered by many authorities to have been " in reality a representation of the head of a palm-tree." The Greeks, also, used floral ornament in the decoration of their pottery. Towards the end of the eighth century, B.c., highly conventionalized plant-form was interspersed with the figures; rosettes, leaves and flowers, with the palmette (or honeysuckle) and the lotus being employed for this purpose ; the suggestion having, in the opinion of Mr. H. B. Walters, been derived from Oriental textiles-in itself an enlightening and instructive theory. But there is, in these examples, no evidence of direct study from Nature. This author, in his "History of Ancient Pottery," gives a detailed account of the development of ornament derived from vegetable forms, to which the student may be referred who desires thoroughly to work out this branch of the subject. It may, for our purposes, be summarised shortly as follows : and the stages indicated may be taken as representative of a normal process of the evolution of pattern. The earliest decoration of this nature consists of a simple repetition of a leaf, which is of too elementary a character to be identified with any specific 


\section{Plant-form in Historical Ornament}

plant. Next, these elementary forms are arranged with more variety, in fours, saltire-wise, or in opposed pairs making a chain-pattern, or ribbon. In the sixth century B.c. the leaf takes on a genuinely naturalistic treatment; for the ivy now becomes easily recognisable in both Greek and South Italian examples; which display admirable arrangements (for decorative purposes) of its foliage, fruit and growth. Other plants which, more or less, appear in ancient pottery of the Greek period, are the vine, pomegranate, acanthus (very late), myrtle, olive, and, of course, especially the lotus and honeysuckle already referred to. The richness and variety of the patterns derived from these two last plants are well-nigh inexhaustible. They have formed the subject of several special monographs; and the student cannot do better than give attention to the numerous examples of them which have been reproduced in one text-book or another, in order to obtain many valuable and suggestive hints for his own applications of other plant-form to similar purposes.

Some of the finest uses of the plant in decoration of the classical ages are to be found in the goldsmiths' and silversmiths' work ; the details consisting almost entirely of foliage exquisitely adapted to the purpose, and occurring either in the form of wreaths or simple repeats of leaves or fruit. These range in succession from objects discovered at Mycenæ (the site of Troy), in the Crimea, and in Crete, to the later Græco-Roman silver-work of which the well-known Treasure of Hildesheim and that of Boscoreale, near Pompeii, may be accepted as representative examples. In these latter, splendidly executed examples of the craft of the silversmith, the plant-form-largely the myrtle-is modelled in high relief, and with a great deal of realism; though the arrangement and general treatment are so conventionalized as to be decorative in a high degree. These are dated, somewhat doubtfully, in the first two centuries of our era. Examples of a skilled use of the flower and plant are also to be found in the mosaics and mural paintings of this time, and the period that elapsed until the fall of the Western Roman Empire.

The dark times which followed this event were marked by 


\section{Plant-form in Historical Ornament}

few works to which the student can be referred, for any purposes of practical art. The decay of craftsmanship, consequent thereupon, meant the loss, at all events for the time, of all the lessons in design which had been laboriously arrived at by preceding generations; and, out of the crude and barbaric decoration of the artizans of the pre-Gothic period, we find arising new arts, on lines sometimes far removed from those of the Classical Age.

In architectural ornament, the Byzantine and Romanesque styles are characterized rather by geometrical patterns and uncouth imagery, than by any attempts at reproduction of natural forms; though the interlacements of the capitals sometimes give a rendering of the vine, and the ivy also occurs. We owe to the Gothic style the revival of nature study. M. S. Reinach says on this subject, "The flora of the country, studied with loving attention, is the sole, or almost the sole, source from which decorations take their motives. It is in this interesting profusion of flowers and foliage that the genius of Gothic architecture is most freely displayed." He instances the Capital of the Vintage in the Cathedral of Rheims as one of the finest works extant of this sort-a truly magnificent example of the adaptation of a growing plant to the enrichment of stone-work; and he says "Since the first century of the Roman Empire, art had never imitated Nature so perfectly, nor has it ever since done so with a like grace and sentiment." (History of Art across the Ages). He might have added-or with so perfect an appreciation of the laws of decoration. This work was done about the year I250.

In almost any British church of the Decorated period, the student will find examples which, if not of the rank of that mentioned above, are yet of the first importance to the ornamentist. Many plants, other than the vine, were brought to this high service. Wheat, for instance, with its symbolical association with the Sacrament of the Lord's Supper, has appealed to more than one of those mediæval artists, whose faith was an ever-present factor in the planning of their masterpieces. And M. Reinach's reference to local flora may be supported by a 


\section{Plant-form in Historical Ornament}

well-known instance in England-that of York Minster, where the Herb Bennet (Herb of St. Benedict), of which an illustration is given in this book, forms one of the chief motives of the architectural ornament in the Mother Church of a district where this plant especially abounds. The Rood-screens of the $1_{5}$ th and early r6th centuries should also receive attention from the decorative artist-especially if he be a sculptor or modeller. The carving of them consists almost wholly of renderings of the Fruitful Vine; a choice resting inevitably on its symbolism; and in the West of England many exquisite translations into wood of this beautiful plant are to be found, the best with which the author is acquainted being on the screen of the church of South Pool in South Devon (see The Studio, Vol. IV, for an illustrated account of it); which is, in its way, as entirely admirable as the Rheims Capital. But other natural forms were used in the minor details of the screens, among which the split pomegranate may be mentioned. The famous screen of Ranworth is rich in painted flowers-the marsh marigold, cornflower, flag and other local plants being especially conspicuous; and in almost every other branch of Northern Gothic art this loving and reverent study of Nature similarly displays itself.

Before leaving this side of the question it may be pointed out that the styles of architecture which, in England, followed the Perpendicular, left little room for the use of flowers or plants as ornament, except in realistic festoons, garlands and swags; which, however decorative in mass, and appropriate (or not) to their surroundings, were, in detail, absolutely wrong in principle. In this category must also be placed the extraordinarily clever wood-carvings of Grinling Gibbons and his school ; work which demonstrates finally the futility of attempts to reproduce the exact form and texture of natural growths for the purpose of ornamentation. A "Gibbons" carving may afford intense interest; and admiration of the wonderful dexterity of the carver comes easily to the beholder; but as decoration, as an enrichment of an object or piece of construction, it fails utterly, by reason of its own overpowering claim to prominence and complete lack of 


\section{Plant-form in Historical Ornament}

subordination to more important matter. A modern instance of symbolical architectural ornament is to be seen in the Lady Chapel of the Benedictine Monastery at Downside, near Bath; which is finely and poetically adorned with carvings based on the many old English flowers with which the name of Our Lady was once associated.

About the middle of the fifteenth century we find a large increase of the use of fruit and flowers, treated with some realism, in Illuminated Manuscripts, chiefly in those of France and the Low Countries, but also, to a less extent, in Germany. This practice is not, as one might suppose, by any means restricted to the borders or marginal ornaments of romances; but appears in those of the Books of Hours and other works of private devotion, which are characteristic of the period, as well as in the larger and more sumptuous missals of the time. The strawberry-both flower and fruit-is an especial favourite. Pinks, roses, forgetme-nots, columbines, irises, daisies, pansies and lilies, also, are intermingled with great profusion, with purely conventional foliage and stems. They are drawn simply, but not without skill both in delineation and in outline, and with a good deal of truth of colour. This simplicity of treatment, and the admixture of the conventional element in the best examples, overpowers the realization, and so avoids any resulting incongruity. But towards the end of the fifteenth and in the beginning of the sixteenth century-especially in Flanders, the naturalistic tendency gets more and more the upper hand. Butterflies and other insects and birds are introduced; and the borders become less an ornament to a page of fine writing than a series of disassociated little pictures; which, in the end, draw to themselves far too much of that attention of the beholder, which is more properly due to the page as a whole and particularly to the contents of it. The result is bad art-a loss of dignity-a failure of design : the inevitable outcome of giving a preponderance too great to one factor in the scheme at the expense of the rest.

During the later Middle Ages, design as applied to textile fabrics reached a height which has never been surpassed for 


\section{Plant-form in Historical Ornament}

richness of effect. Brocades and velvets were decorated with elaborate patterns, admirably arranged, in which highly conventionalized flowers, fruits and leaves, or compositions of all these elements, formed an important factor. These patterns show strong Oriental influence; and in origin are largely referable to South Italy and Sicily; but their use was common over the whole of Western Europe, especially for ecclesiastical vestments, and examples of them are to be found in I5th and early I6th century pictures of most of the schools of painting of that period. There are also a number of very fine designs of the same nature still remaining on the Painted Rood-screens of East Anglia. This class of ornament lost much of its simplicity and dignity in succeeding years; but a brief note is deserved by the English fabrics of the I8th century. Figured silks made for the rich costume of that time were largely decorated with floral patterns composed with a good deal of skill and suitability to their special purpose. In the Victoria and Albert Museum, South Kensington, is a magnificent collection of ornamental textiles chosen especially from the point of view of pattern; as well as a large series of original designs of this last class, which, in response to the fashion of to-day, are proving very serviceable to " designers" in search of ready-made patterns.

Tapestry of various kinds supplies some models of a good use of plant-form, particularly in the matter of borders ; though in many of these are to be seen the faults pointed out as existing in the Grinling Gibbons wood-carving, namely, an imitation, too close, of Nature. But the earlier specimens have, often, beautifully arranged grounds of flowers broadly and simply treated, as well as rich and highly decorative foliage.

Within the close limits of an essay of this description one can hardly even name all the varied branches of applied art which might serve as good examples for study. But, in addition to those mentioned above, a word of reference must be given to the old Persian and Rhodian pottery and tiles; the masterly treatment of foliage by the German and French engravers of ornament in the 16th century, and the furniture of the same 


\section{Plant-form in Historical Ornament}

period; the English wrought-iron gates and screens of the late I7th and early I8th centuries, in which the apple-leaf is so pleasing an element; and the Japanese lacquer, inlay and metal-work - so minute and delicate and yet so entirely conservative of the true feeling of Nature. These, and many other classes of work should be referred to by the student. But he must remember that imitation of them is mere futility. His business it is, to ascertain by close and intelligent observation, what were the underlying principles which guided the old craftsmen to results so perfect; and to strive to realize them in his own separate endeavours. 



\section{III.-A Note on the Illustrations}

THESE photographs of plant-form have been chosen from a very large number made with the one object of representing the essential characteristics of flower, fruit, leaf and growth, as they might be supposed to appeal to the artist and the designer. They are not intended to take the place of Nature ; to be a substitute in any sense for that direct study which is the foundation of all good work in the arts. And yet it is hoped that they may serve as an aid to memory in dark or unseasonable days, when the original is not available. Every effort has been made, therefore, to keep as closely as possible to Nature itself. The examples do not include one single "sport" or abnormal growth. There is not one rare or curious plant among them. All are easily accessible in their natural state and most are easily cultivable. And, without in the least decrying valuable manuals of plantform which have recently appeared, it has been felt, in relying exclusively on photographs, that there is a strong educational advantage in getting a student to make his or her own drawing uninfluenced by the versions, however admirable, of others.

It is hoped that the book may appeal to many others than those who are concerned with putting its contents to professional uses. Nature study, in the wholesome sense of the word, should require a multitude of examples; and this purpose has also been kept in mind, in choosing and arranging the reproductions. The notes which accompany the latter endeavour to indicate very briefly some of the human interest attached to them, and may induce some readers to take up thoroughly the delightful study of the large lore, traditional and otherwise, which belongs already to these growths from the world's garden. 


\section{PEAR BLOSSOM.}

Possibly nothing is more characteristic of an English garden than its pear-trees at the time of their flowering; and the blossom, so beautiful in its mass, is still more so in the detail of its slender and fragile grace. The tree is an old friend of gardeners. Gerard refers to the collections, not only of Mr. Vincent Pointer, already mentioned, but also of "Mr. Henry Banbury, of Touthill Street, neere Westminster, and likewise in the grounds of a diligent and most affectionate lover of plants, Mr. Warner, neere Horsey Downe by London "-localities where the pear-tree--though a brave and tenacious tenant of its old abodes-is now, one fears, somewhat to seek. The wood of the wild pear-tree, it is interesting to note, was much used for early engravings ; and it is of this that the blocks of the "Herball" were cut. The blossom has been but little used by designers-though the omission is somewhat strange.

\section{APPLE FRUIT.}

The apple is the oldest of all fruits in tradition, for it has borne, from time immemorial, the burden of having been the instrument of the Fall. Yet that it was held in honour among the Hebrews is shown by its mention in the Song of Solomon, with the Rose of Sharon and the Lily of the Valleys. "As the appletree among the trees of the wood, so is my beloved among the sons ;" and again in Proverbs, "A word fitly spoken is like apples of gold in pictures of silver." It has also played a large part in ancient mythology; witness the Apple of Discord, and the Gardens of the Hesperides, wherein were the famous golden apples. In ornament, both leaves and fruit have been largely used. The tree itself was a favourite with the early illustrators of books, and it frequently occurs also in tapestry and needlework, to which its simplicity of line readily lends itself. One cannot give more than a bare reference to the folk-lore of the apple and to the curious customs and quaint rhymes with which its cultivation is in this country associated. 


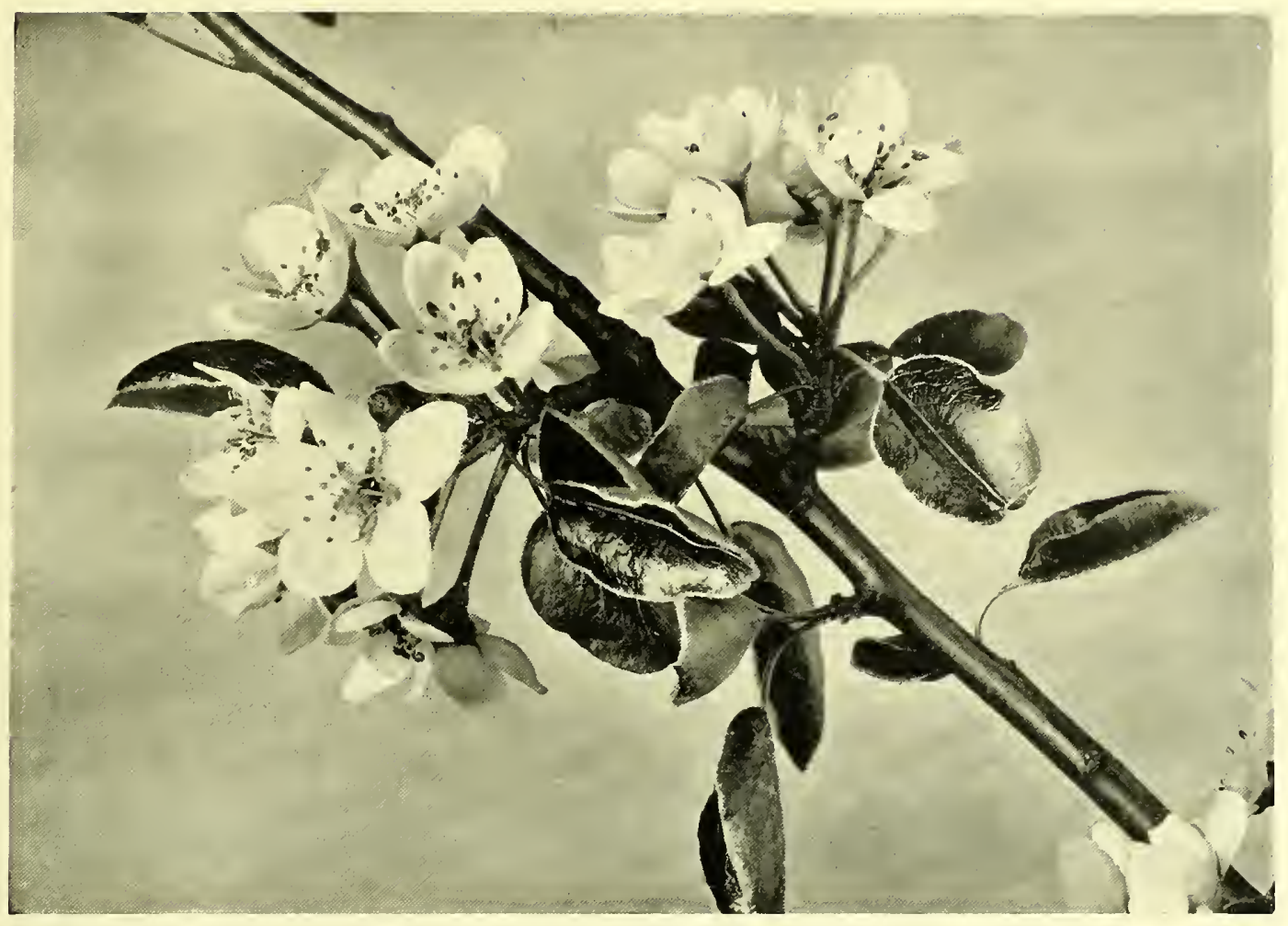

PEAR BLOSSOM.

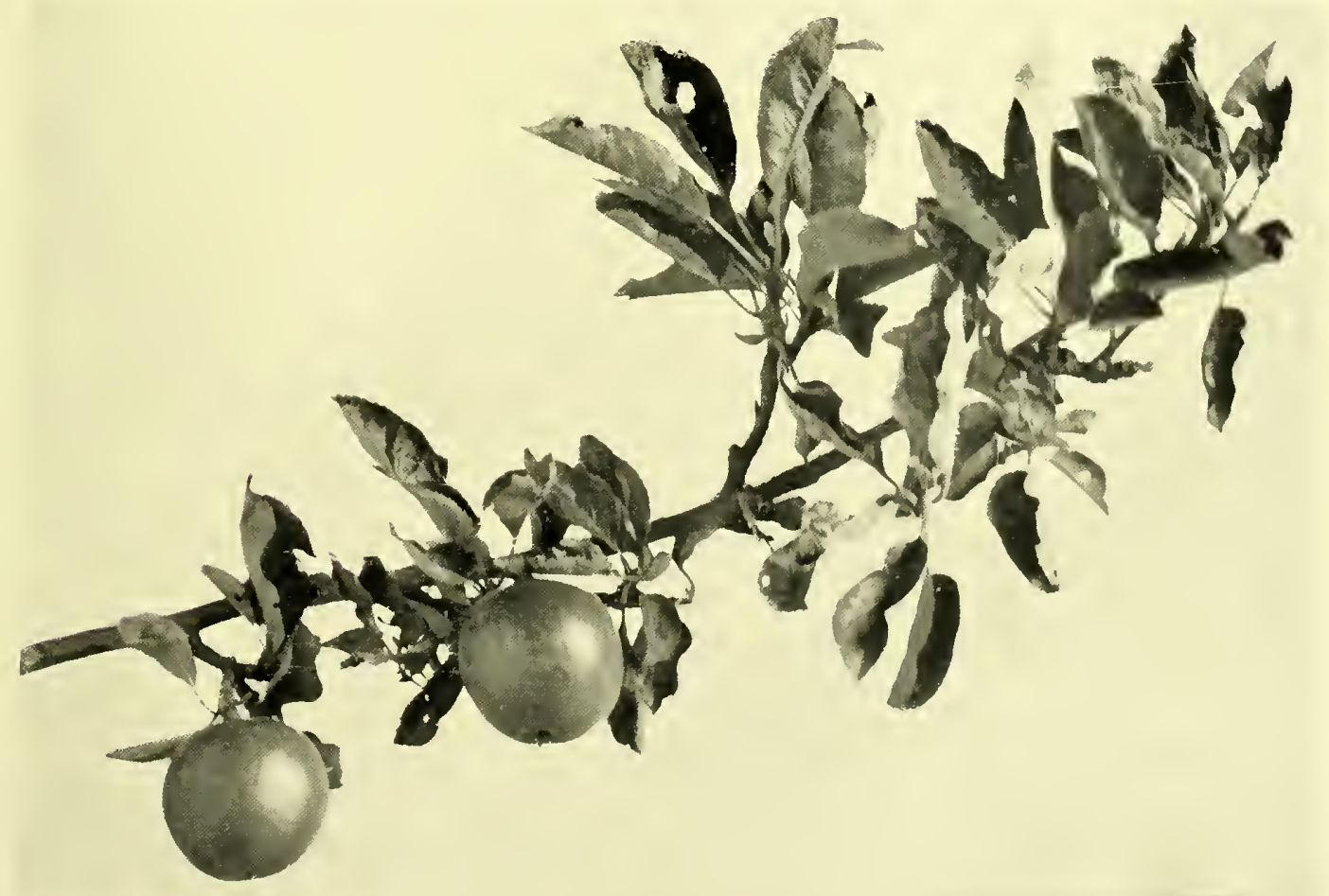

APPLE FRUIT, 



\section{FRONTISPIECE. THE GRAPE VINE.}

It would be easy to write a whole book on the subject of the artistic uses of the vine-one of the oldest and best favoured of all plants that ever inspired a pattern. Some of the chief of them have already been indicated in our introductory chapters ; here one can do little more than emphasize the great natural decorative qualities of the plant, which arranges itself in the course of its growth with such infinite variety of grace that, old as is the theme, the designer need never be at a loss for a new subject. The symbolism of the vine, in Christian art, is well known ; and as an attribute of the Second Person of the Trinity, it appears on Rood-screens, in Illuminated Manuscripts, Stained Glass, Sculptured and other forms of ornament. The old physicians used its leaves, stalks and unripe fruit for many ailments, especially as an astringent; and for an example of the historical antiquity of the plant, one need only recall its earliest mention in the Bible, as the subject of one of Pharaoh's dreams. 


\section{4. FLOWERING CURRANT AND RED CURRANT FRUIT.}

These two plants may well be considered together ; for the one seems to supply the deficiencies of the other. The Flowering Currant, which is a comparatively modern denizen of our gardens, is a particularly valuable addition to a shrubbery, and the rich masses of its crimson flowers, not unlike bunches of grapes in their growth, entitle it to more favour than it generally receives. Its foliage is insignificant and fruit worthless; but for these, we may turn to the ordinary edible currant, with its finely shaped foliage and graceful pendulous fruit. The old German and Bohemian names of the currant, as given by Gerard, associate it with St. John, but the herbalist does not seem to have been acquainted with the flowering variety. 


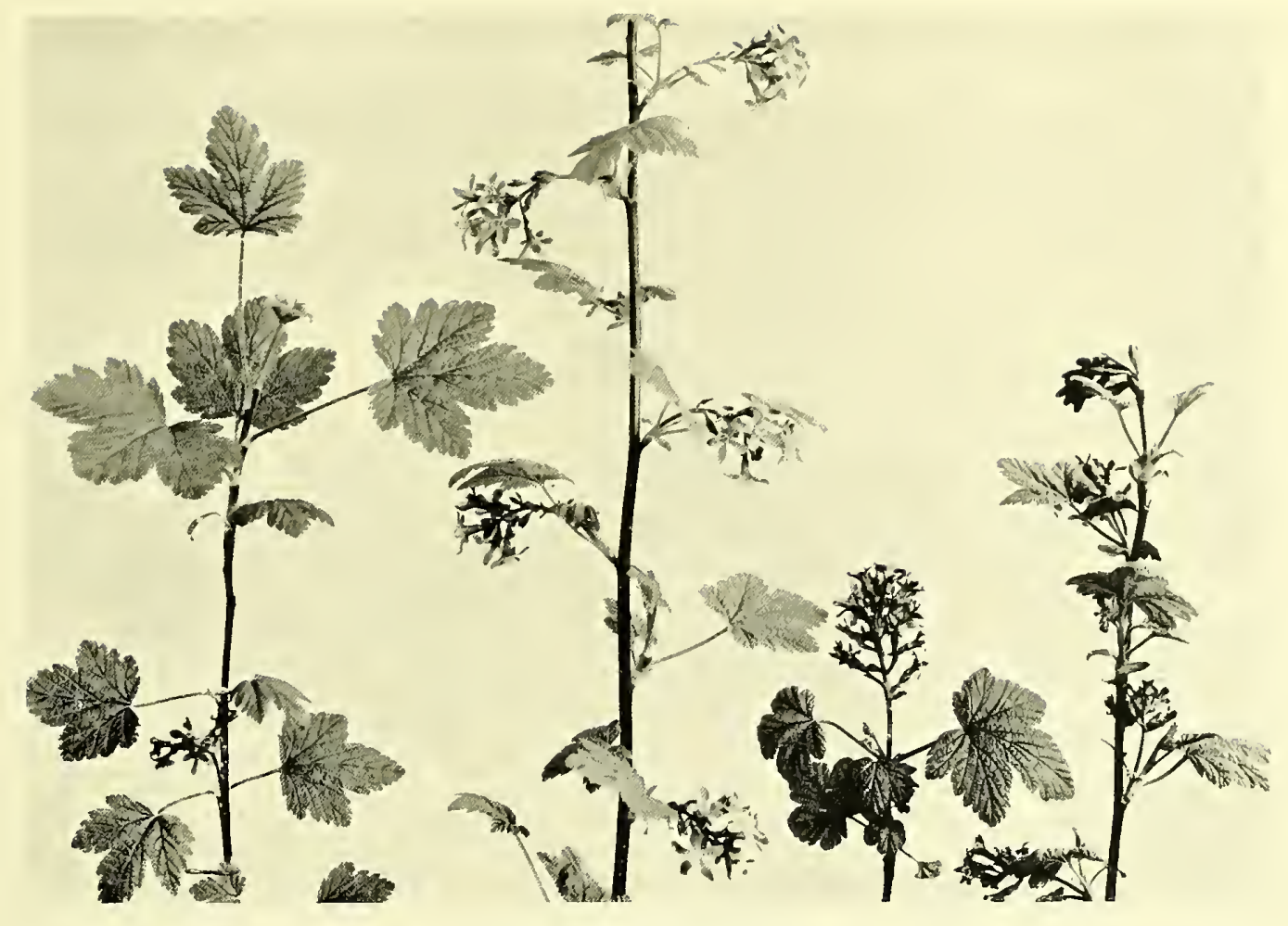

FLOWERING CURRANT.

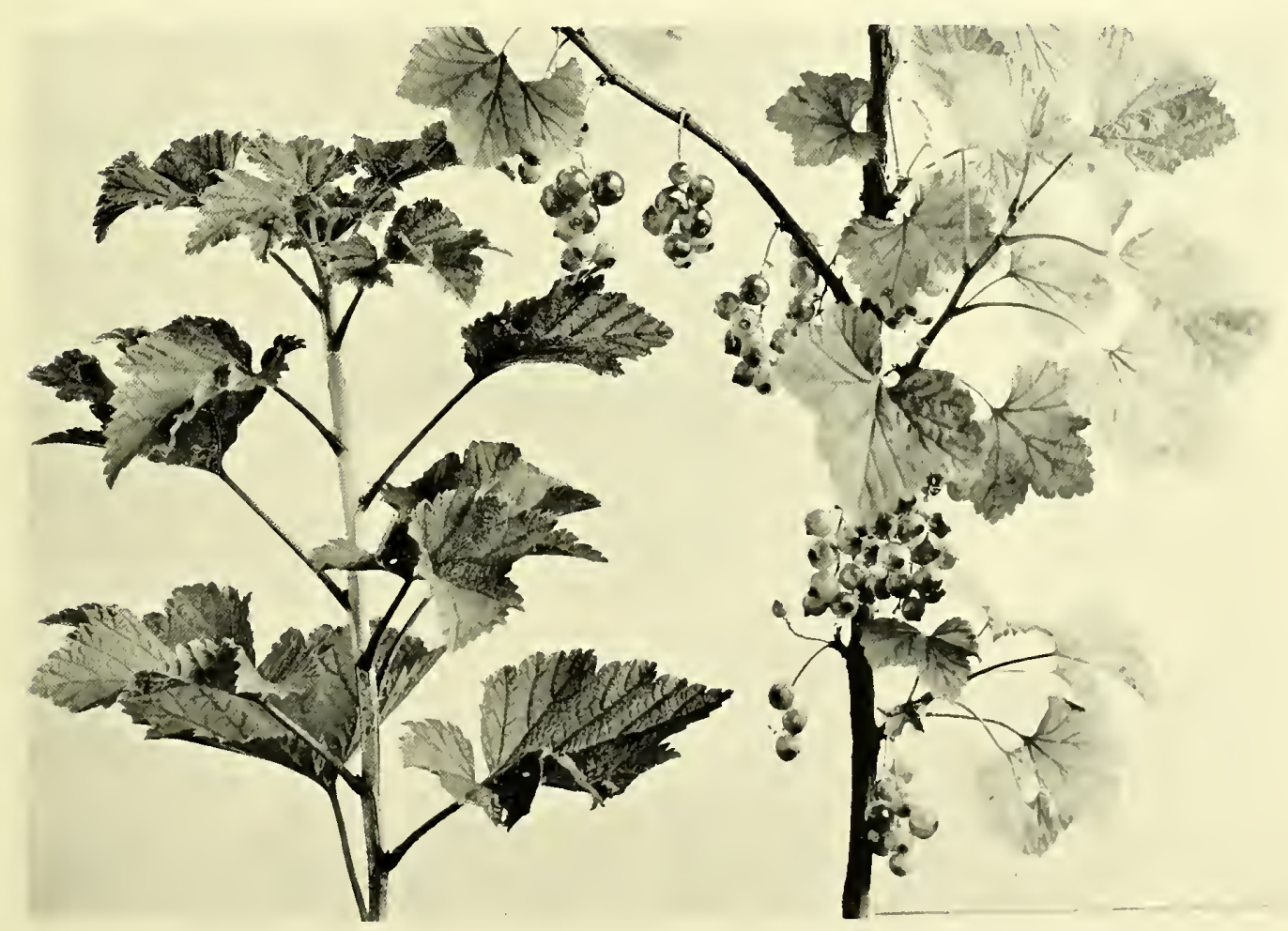

RED CURLANT FRUIT 



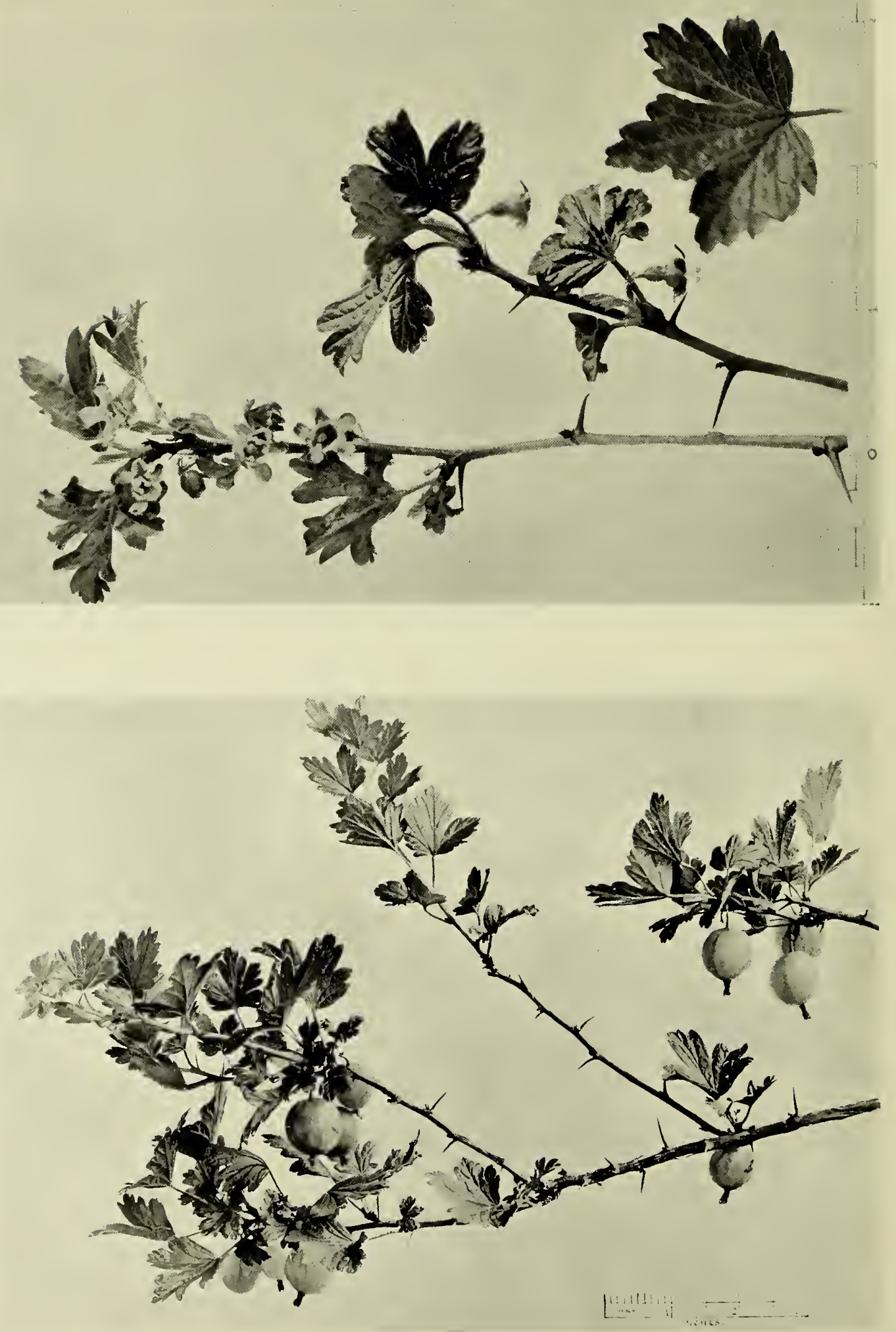

GOOSEBERRY FRUIT. 


\section{6. GOOSEBERRY.}

The Gooseberry, which, as Gerard remarks, was also called "Fea-berry bush in Cheshire, my native county," has no claims upon the imagination, derived from tradition or folk-lore. It has served a useful domestic office only, hitherto ; and the delicacy of its structure, the beauty of its foliage, and the simple curves of its fruit gracefully massed on the lower side of heavy clusters of leaves, may well recommend it to the designer. Of its old uses, Gerard mentions several which might be worthy of revival -particularly the fruit "in divers sauces for meat," and the young and tender leaves as a salad. "The juice of the green gooseberries," says he, moreover, "cureth all inflammations, erysipelas and S. Anthonies' fire." 


\section{RASPBERRY.}

The Raspberry (Rubus Idceus) takes its botanical name from Mount Ida, where it grew luxuriously; and is mentioned by Pliny as Idaa. By Gerard it is called The Raspis bush, Hindeberry, or Framboise bush. He says "It groweth not wilde that I know of, except in the field by a village in Lancashire, called Harwood, not far from Blackburne. I found it among the bushes of a causey, neere unto a village called Wisterton, where I went to schoole." $\mathrm{He}$ describes the fruit of the garden variety, as " in taste not very pleasant," a point in which he will not nowadays find much support. It occurs in the borders of old MSS. and a well-grown cane, with its spreading foliage, is a plant to be recommended to the study of artists. 


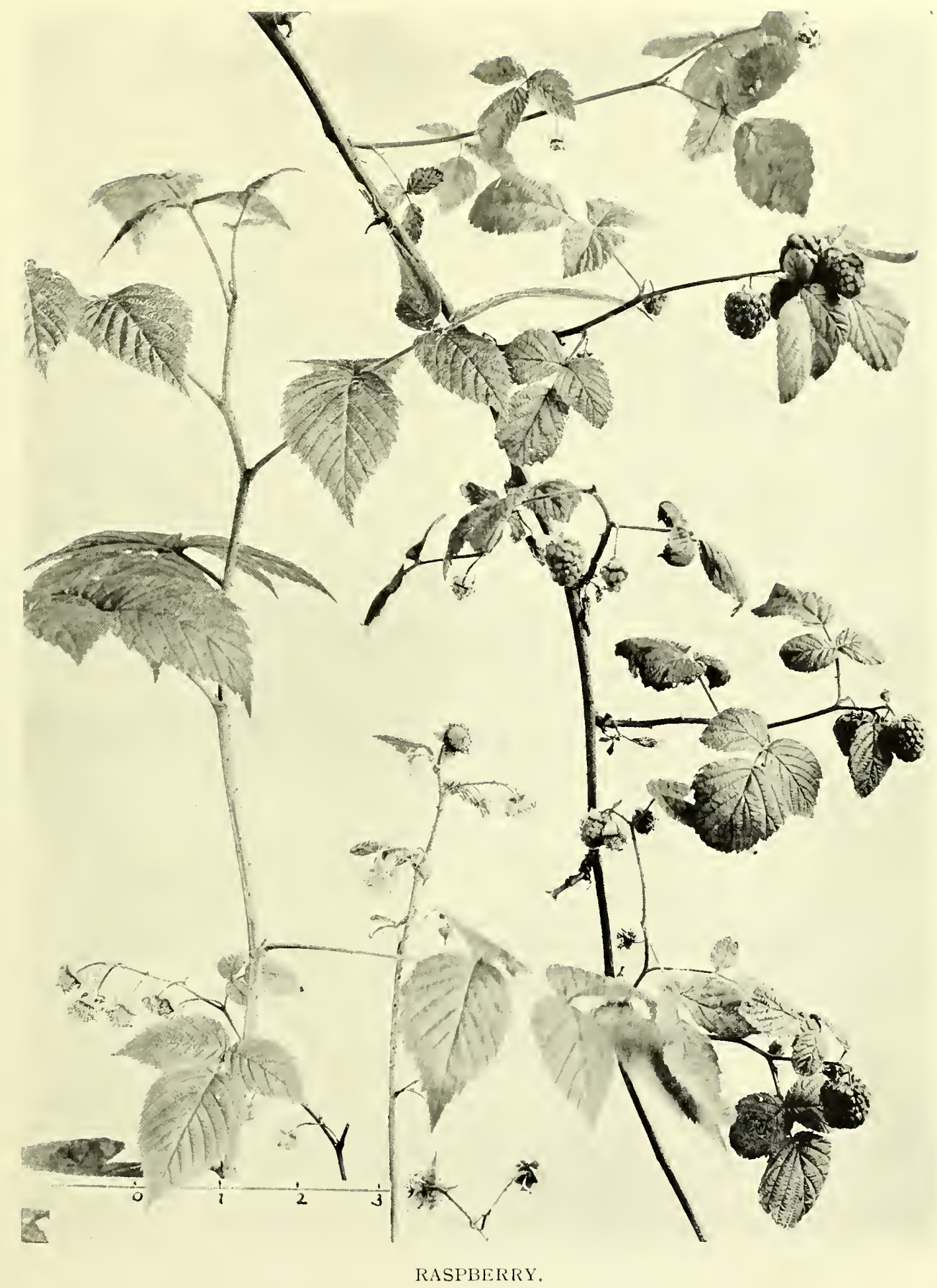






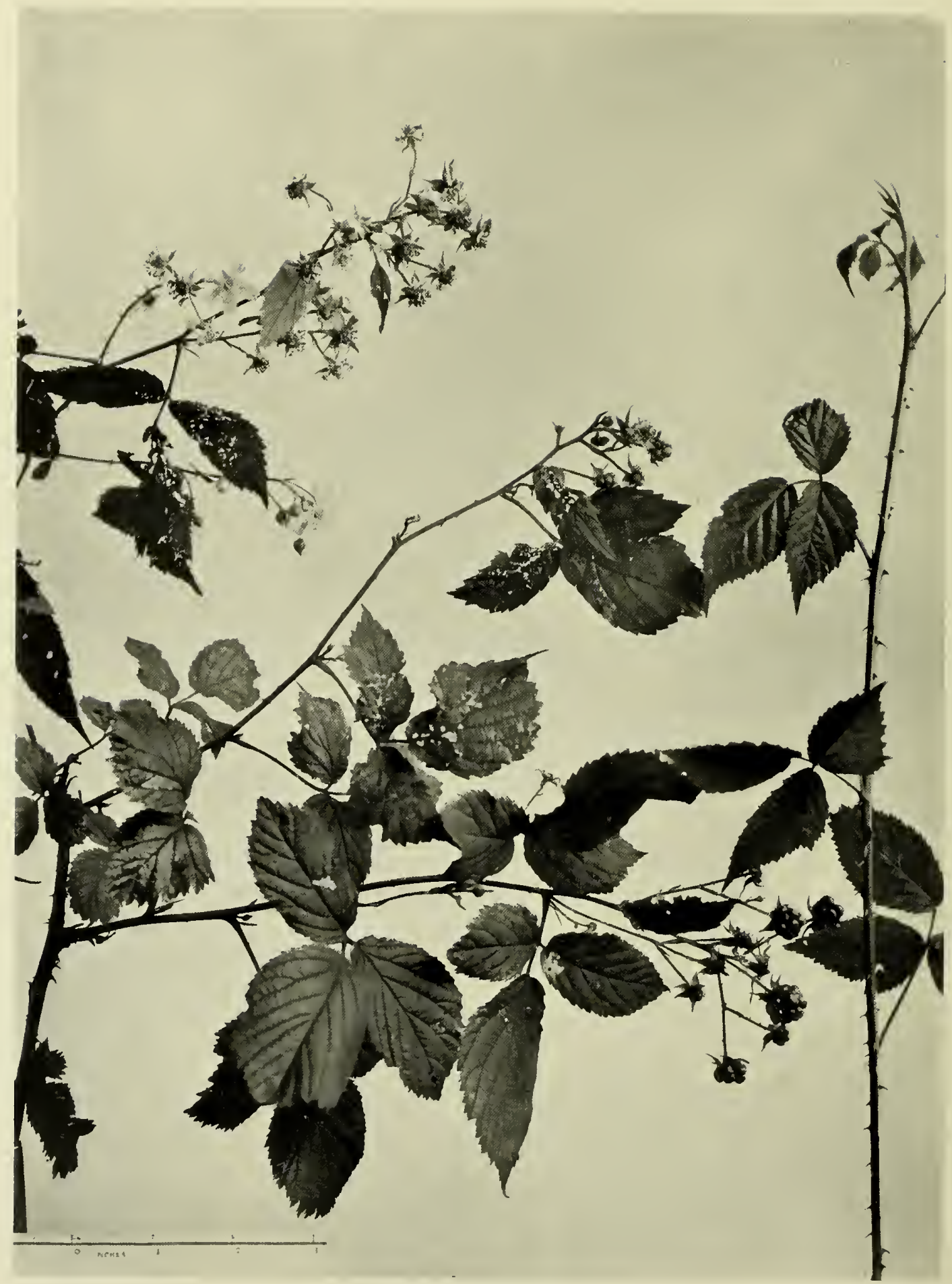

BLACKBERRY 


\section{BLACKBERRY.}

One of the most beautiful, both in growth, foliage and fruit of all British plants, is the Blackberry; of which Gerard's description can hardly be improved upon- " The common bramble bringeth forth slender branches, long, tough, easily bowed, ramping among hedges and whatsoever stands neere unto it; armed with hard and sharpe prickles." In the r6th century it was deliberately planted by farmers to strengthen their hedges; and this doubtless explains to some extent its wide and general occurrence. It is the especial harvest of children in this country; and is immortalized in the story of the Babes in the Wood. But in certain districts of the North of France, it is looked upon as accursed, the legend being that of it was fashioned the Crown of Thorns; and no one will touch a berry for any purpose. In the late autumn the foliage takes on great splendour of colour, ranging from pale yellow to the deepest purples and crimson. 


\section{PLUM BLOSSOM.}

There are few more beautiful blossoms of the spring than those of any variety of Plum. The flower with its interesting growth, is among those most favoured by the Chinese and Japanese artists and craftsmen, though in Europe it has never received the attention it so well deserves. In those countries it is an emblem of youth and good fortune; and a splendid example of the treatment of which it is capable may be seen on the so-called "hawthorn-jars" of Chinese Porcelain-the flower actually represented being really that of a variety of prunus. Gerard had no less than 60 different sorts in his garden, and his friend, "Mr. Vincent Pointer, of Twickenham," many more. Indeed, its distribution seems to be world-wide.

\section{IO. HOLLY.}

The one great association of the Holly with Christmas has its origin in practices which long preceded the Christian Era. The Feast of Saturn fell in the winter time, and the Romans celebrated it by decorating their houses with holly and evergreens, and the interchange of bunches thereof as tokens of good will. "Our Teutonic ancestors," says Mr. F. E. Hulme, " hung the verdant boughs of the holly in their dwellings, that the sylvan spirits might, fleeing from the region of winter in the stormswept woods, find in its shelter a welcome resting-place." The holly with its berries is yet another plant, said to have been used for the Crown of Thorns. It grows to a great age, and occasionally attains considerable height and girth. Its wood is most valuable for furniture and for implements requiring great toughness, and its foliage furnished a frequent theme to the German engravers of ornament in the I6th century. Holly was one of the devices of Charles the Bold, Duke of Burgandy (died I475), with the motto Qui s'y frotte, s'y pique. But it is, after all, on the old Christian tradition that our love for the holly must always rest. As the Cornish poet, the Rev. R. S. Hawker, of Morwenstow, sang,

"So, of all that grow by the King's highway,

I love that tree the best;

'Tis a bower for the birds upon Christmas Day,

The bush of the bleeding breast.

$\mathrm{O}$ ! the holly with her drops of blood for me,

For that is our sweet Aunt Mary's tree." 

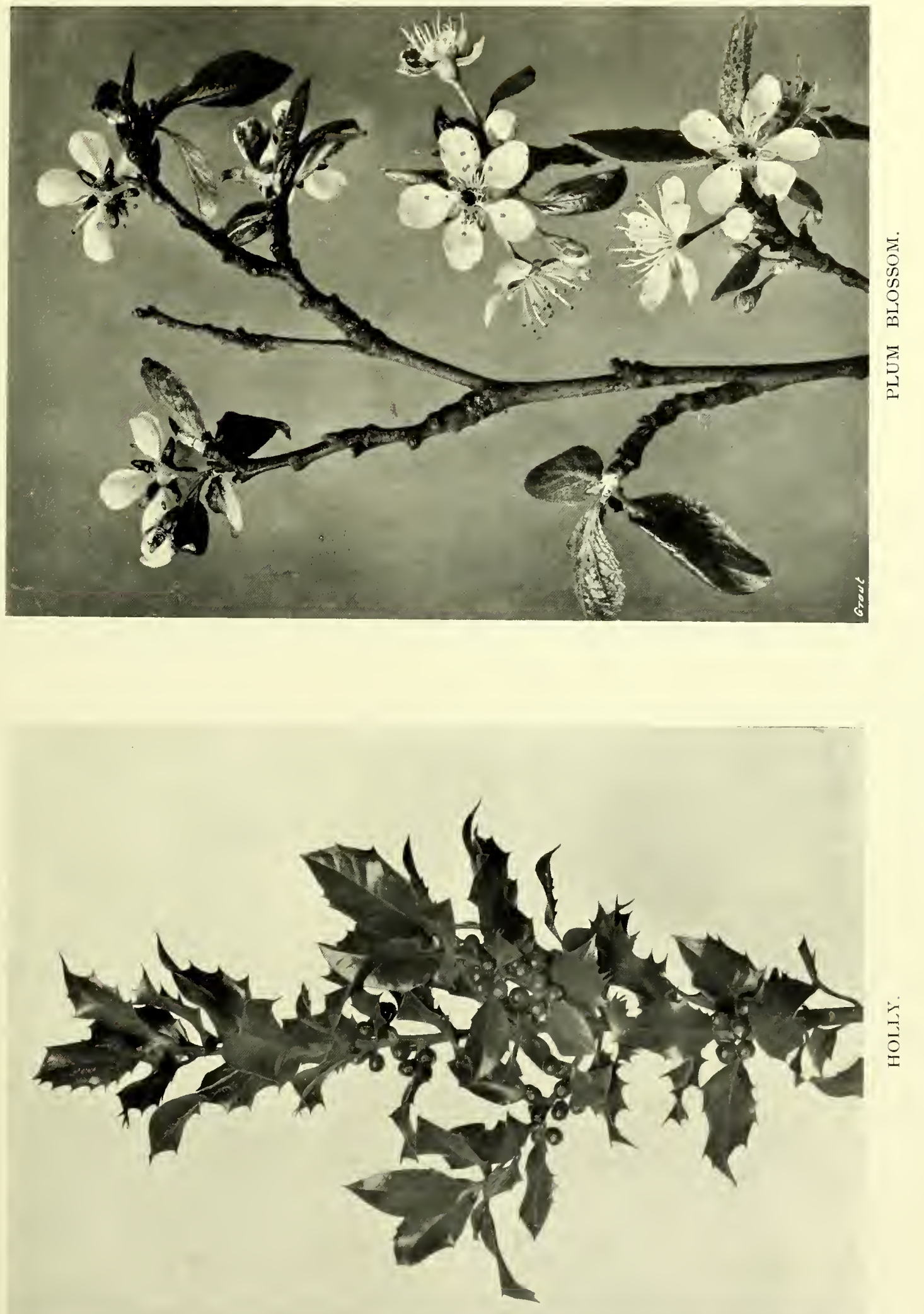



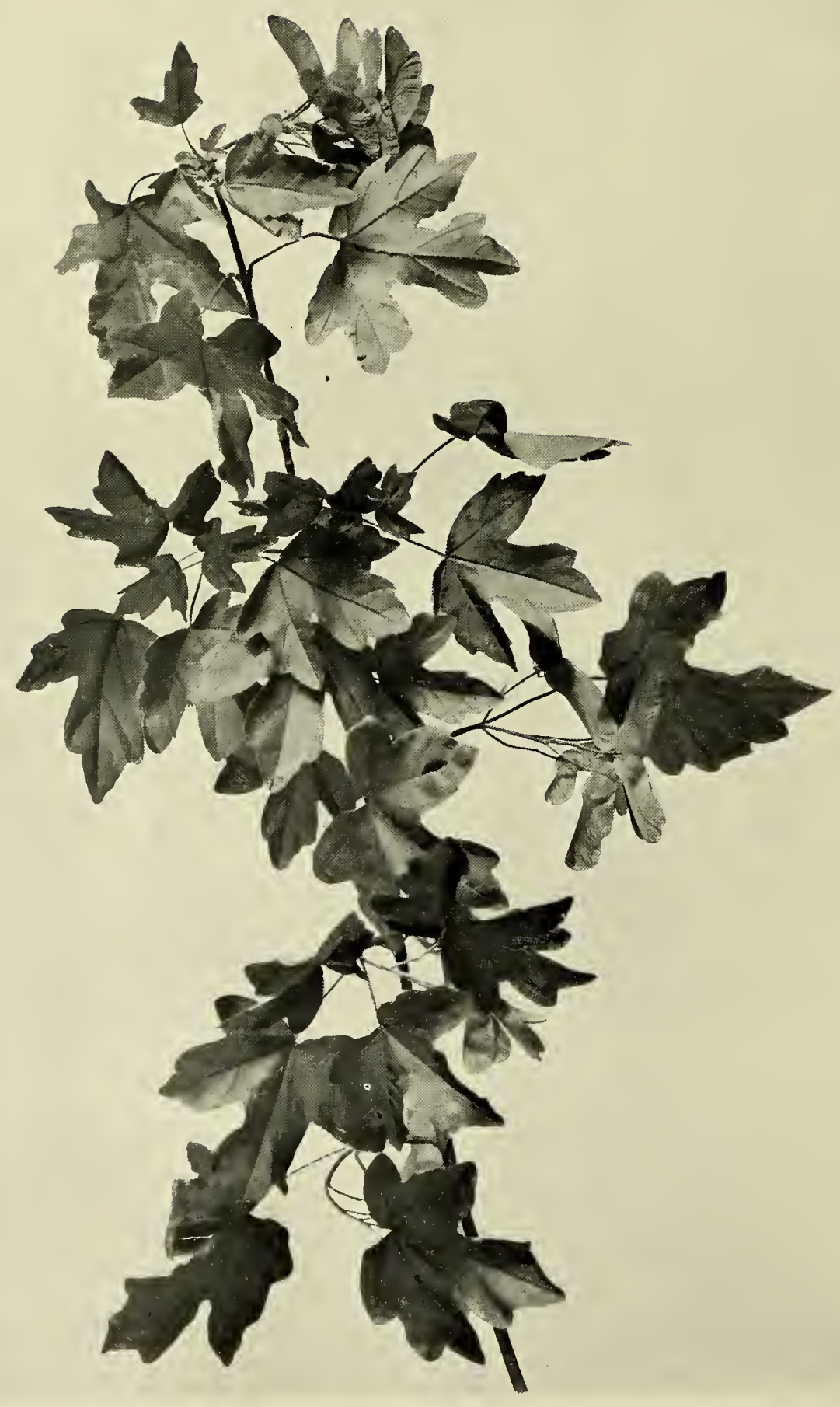

 
II. FIELD MAPLE, FOLIAGE AND SEED.

The Field, or, as Gerard calls it, the small or hedge maple, is indigenous in this country; and was known to the AngloSaxons as the mapul. It was a favourite with the old gardeners, who used to trim it into shapes of bird and beast, as they handled box and yew. The leaves and fruit are beautiful in form, and often occur in sculptured ornament of the Decorated style in architecture, while the colours which they develop in autumn are among the most splendid of the palette of Nature in the fall. The wood is well known to students of furniture; and the drinking-bowls, or mazers, now so highly prized by collectors, were of maple-wood mounted with silver, an old name for the tree being the maser-tree. In Japanese art of every kind the maple leaf plays a conspicuous part, and the poetry and folk-lore of that country is full of references thereto. 


\section{I2. HAZEL CATKINS.}

The hazel is one of the trees especially sacred to Thor ; and its folk-lore is widely spread and voluminous. It was almost generally believed that hazel was not only never struck by lightning, but that it afforded protection both-as one writer puts it - from heavenly and earthly fire. On St. John's Day in some parts of France, people dance three times round the bonfires, holding bunches of hazel twigs. Snakes dislike hazel; and in one old fairy tale the hero cuts off the seven heads of a dragon with a rod of this tree. It was a law of the Ostrogoths that, of all trees in the wood, the oak and the hazel had peace, i.e., they were not to be lopped or felled; and these two trees are still said, in Germany, to be enemies. The uses of the hazel twig and of hazel nuts in divination are too well known to need repetition, and the nut ceremonies of All Hallow E'en are still practised sufficiently often not to be forgotten. Doctor William Turner, in his Herbal ( 1568 ) gives the following curious note, "There are some that holde that if nutt shelles be burnt and made lyke ashes, if they be layed to the hinder heade of the childer that have graye eyes, that they will make them black." Gerard gives "azlets" and "blowings" as alternative names of the hazel catkins, which latter term all the early herbals in English make use of, except Turner, who does not mention them. 


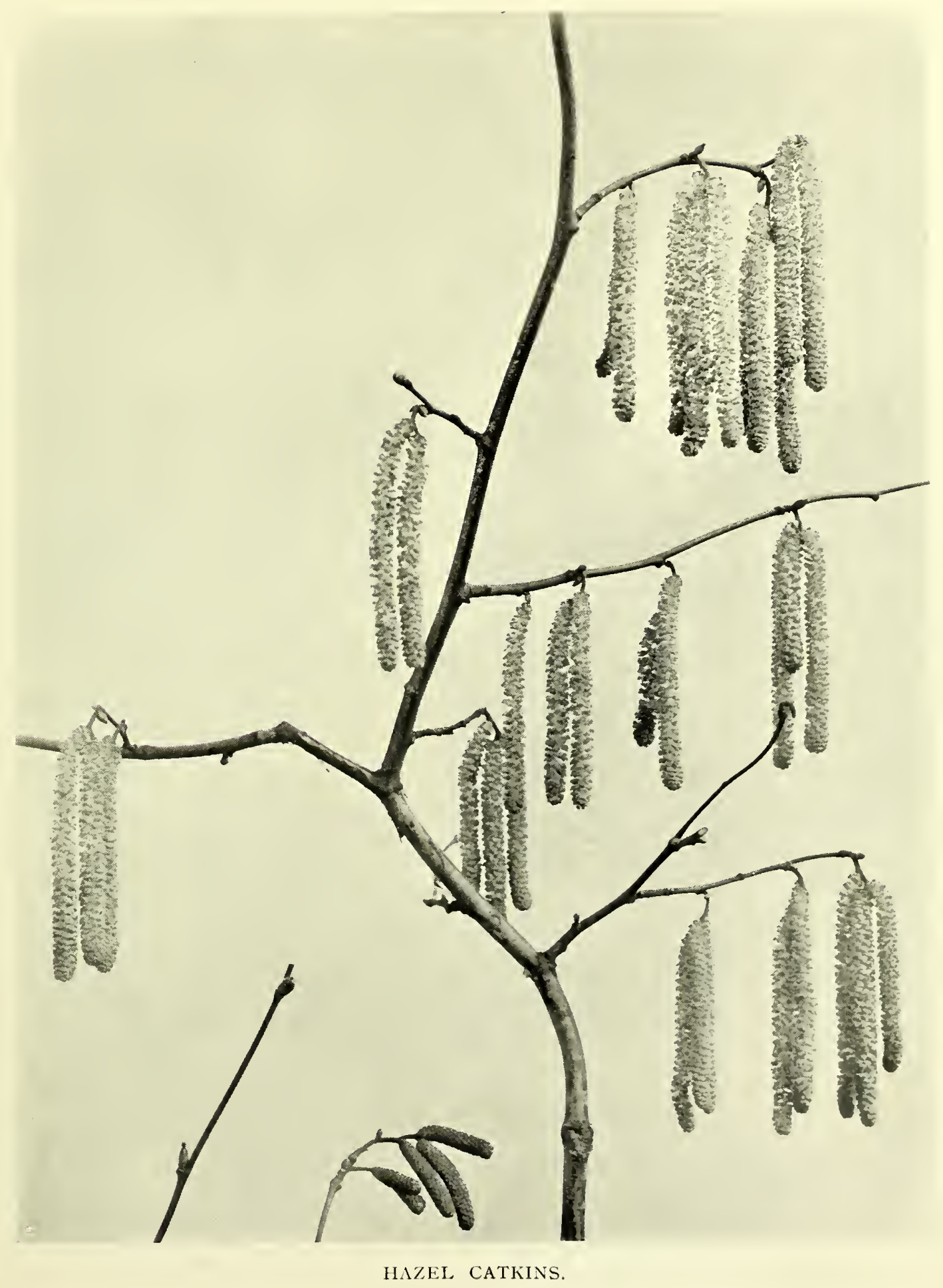





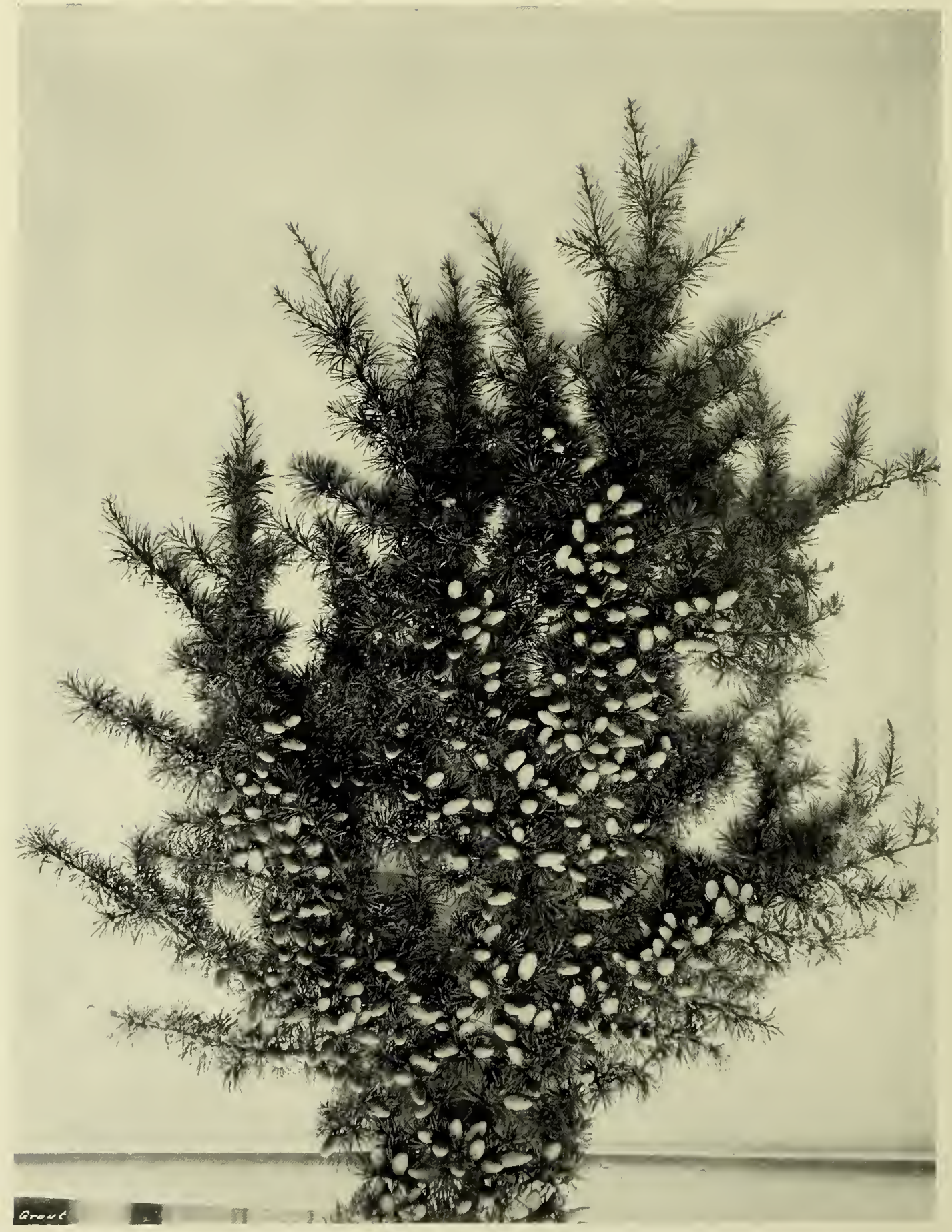

CEDAR OF LEBANON, MALE CONES. 


\section{CEDAR OF LEBANON.}

The Cedar of Lebanon is the most celebrated of its genus, and the grand irregularity of its form has compelled the admiration of writers of all ages. The Old Testament has many references to it, always as a symbol of strength and magnificence in the allusive passages, as in the Parable of Jotham, and in the bitter irony of the reply of King Jehoash to Amaziah, "The thistle that was in Lebanon sent to the cedar that was in Lebanon, saying Give thy daughter to my son to wife ; and there passed by a wild beast that was in Lebanon and trode down the thistle." The tree is a native of Mounts Libanus, Amances and Taurus, but there are probably now more cedars in Britain than in Palestine. In I696, Maundrell, on his journey from Alleppo to Jerusalem counted I6 great trees only, though there were many smaller ones; and the forests probably never recovered the devastation caused by Solomon's 80,000 hewers. The growth of the tree is picturesque throughout, and especially so in its earlier stages ; and its needles and clustered cones should lend themselves well to fine artistic treatment in pattern. 
I4. BROOM.

Broom is one of the most anciently-known and widelydistributed of shrubs. It occurs throughout Europe and also in North Africa and the west of Asia; and has preserved its name in this country practically without change since Anglo-Saxon times. The Southwark Herbal mentions it as furnishing valuable medical specifics, and it is interesting to learn that "distilled water of Broome floures" was a favourite remedy with Henry VIII., for "surfets and diseases raising therefrom." The growth of this shrub, with its little leaves and clusters of butterfly-shaped flowers, is very beautiful; and few plants are more worthy of study from this point of view, or more generally acceptable for the purpose. When the broom has plenty of blossom, it is a sign of a good harvest. It is generally said that its name is derived from its employment as a domestic implement, but it seems at least possible that the reverse may be the case. Broomtops were once used for flavouring beer before hops became common. It furnishes the badge of the Scottish clan Forbes. In addition to its famous association with the Plantagenets in England, it was chosen by St. Louis of France as his own badge, and, on his marriage in I23I, he instituted the Order of the "Cosse de Genest" with a sprig of broom for its device and the motto Exaltat humiles. 


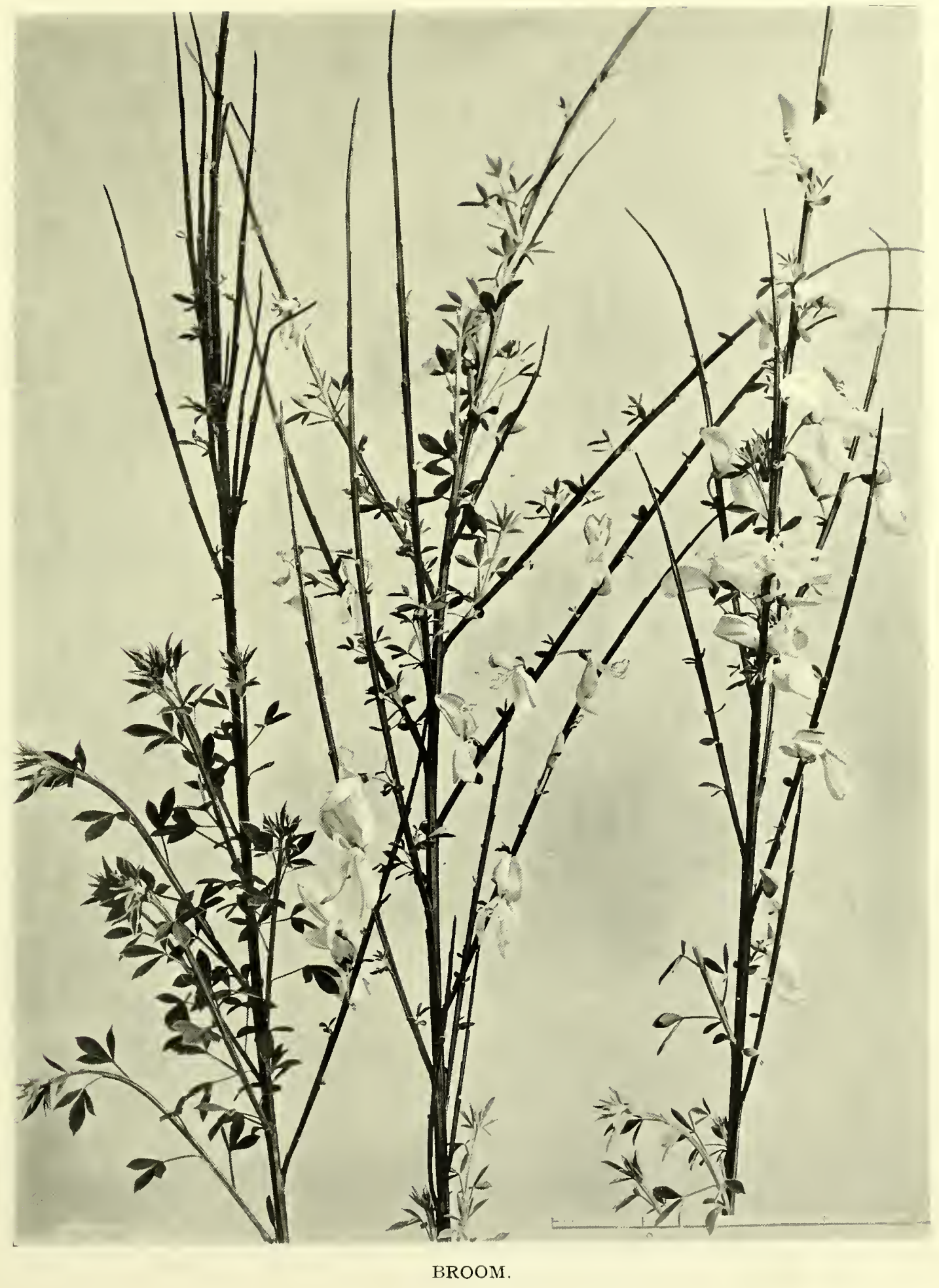





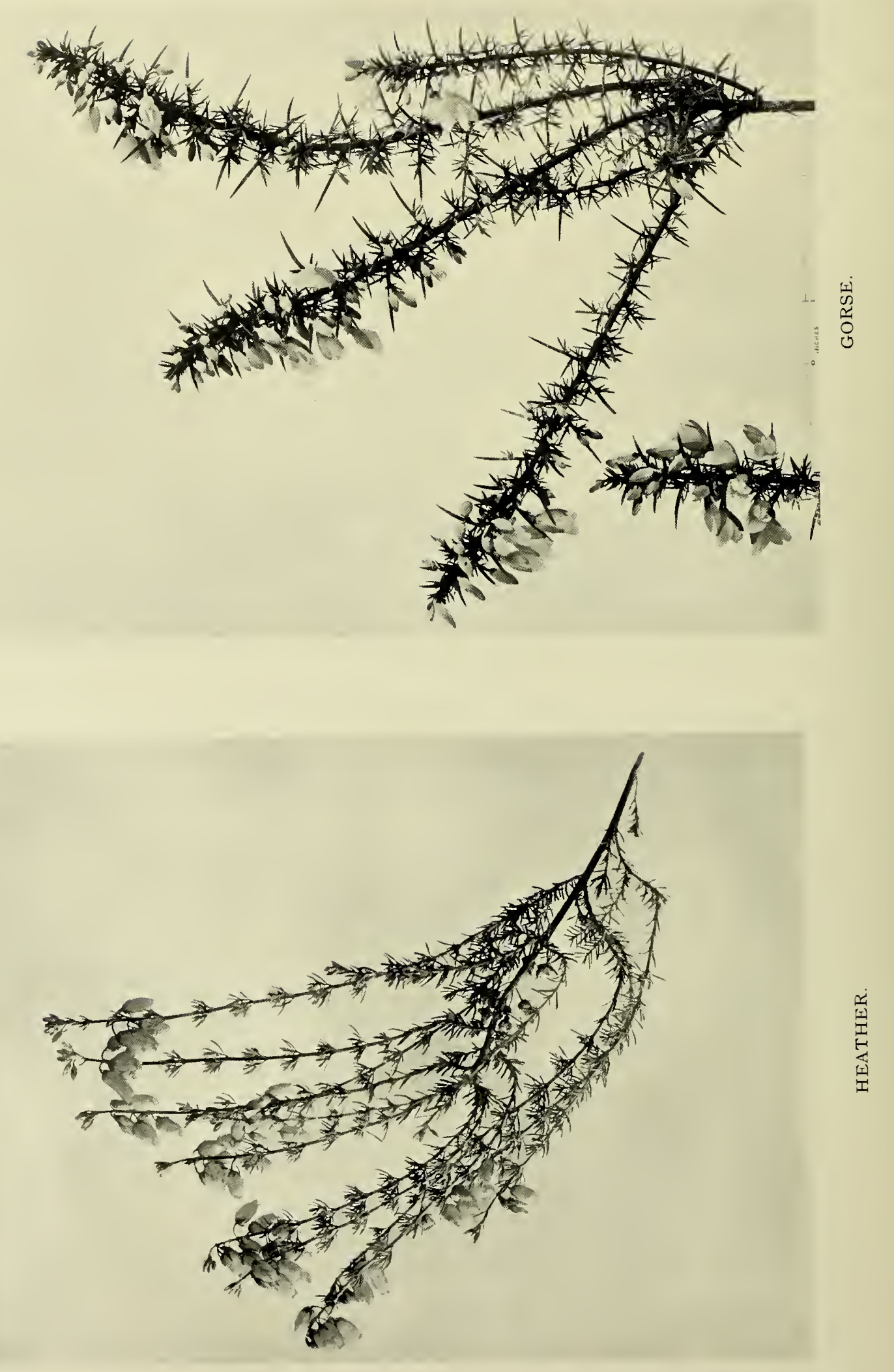
I5. GORSE.

The old saw says

"When the gorse goes out of bloom

Kissing goes out of favour,"

but the couplet is merely a pleasant negation; for the brave plant never rests and one can always find somewhere, in a colony of it, that dash of gold which, in mass, lends such richness to a hill side. Furze and whin are other names, which, as Mr. F. E. Hulme has pointed out, have led to some amusing tautology.

\section{I6. HEATHER.}

Heather is indigenous to this country, and, happily, it is widely spread; for, beautiful as its masses of colour appear in a landscape, it is still more charming in detail. The old Herbals all refer to several varieties of it, some of which are, perhaps, not quite scientifically classified. Parkinson says that its "leaves and flowers made into a decoction are good against the sting or bitings of serpents." And further that "the honey that the bees take from the flowers of heath is called mel improbum, but we have not found any ill quality therein in our land; only it will be higher coloured then in those places where no heath groweth." The delicate, wax-like flowers of the finer varieties of heather, and their exquisite arrangement on the stems of the plant should be highly suggestive to decorative artists. 
I7, I8. WISTARIA FLOWERS AND STEM.

Although the Wistaria has for a long time been domiciled in England, and its rich masses of grape-like flowers, mauve or more rarely white, and the weird and fascinating tangles of its stems, adorn many old brick houses in the southern part of these islands, one associates it especially with Japan. There, its cultivation has been carried to an extraordinary pitch by that nation of flower lovers. It is more often arranged as a pergola than trained against a wall or screen, and the effect of the myriads of pendent blossoms seen against their green foliage and the interlacement of the stems of the ancient plants, is, in its way, unrivalled. Japanese applied art contains, naturally, numbers of examples of its use in decoration, but western artists have in this respect so far greatly neglected their opportunities. 

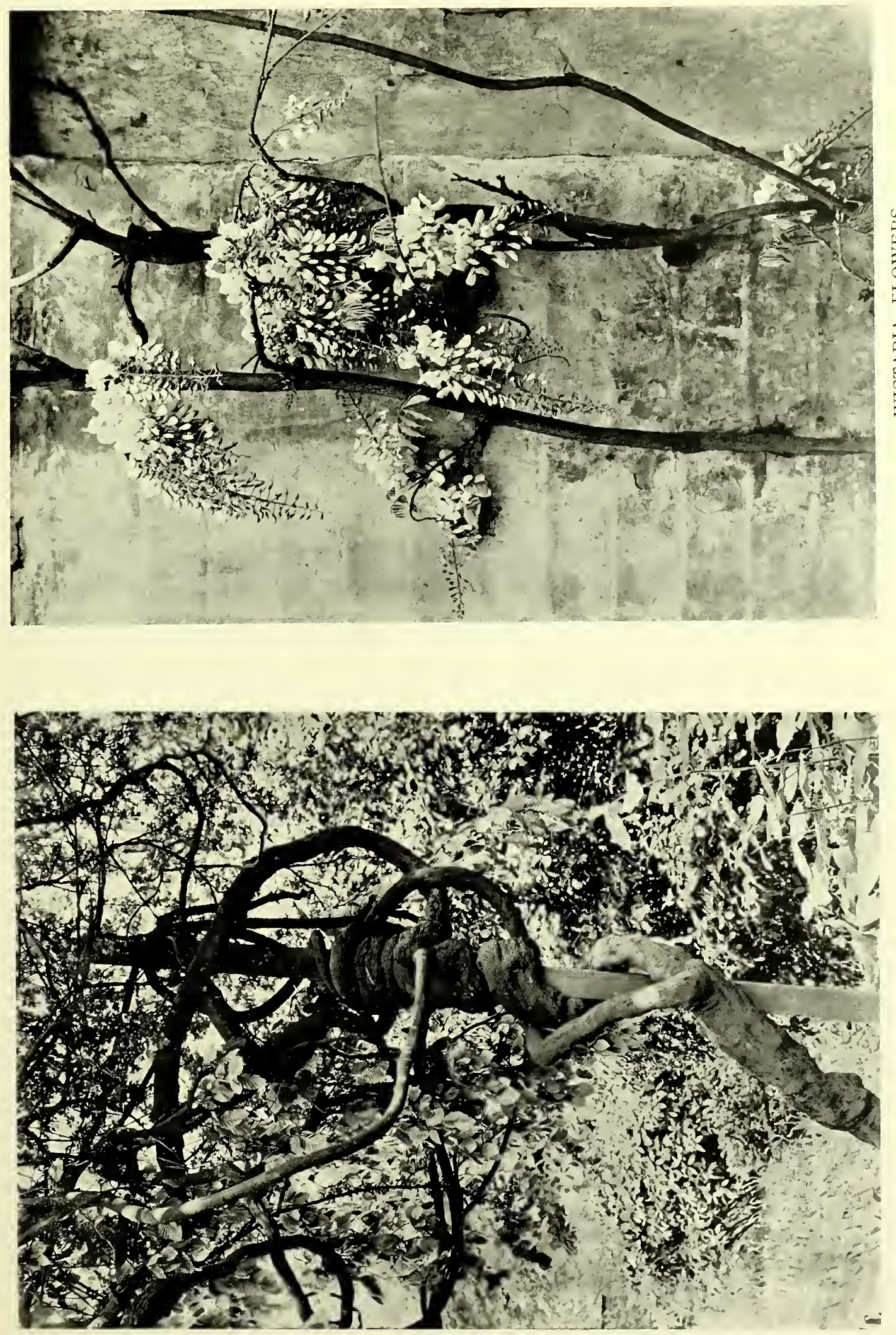




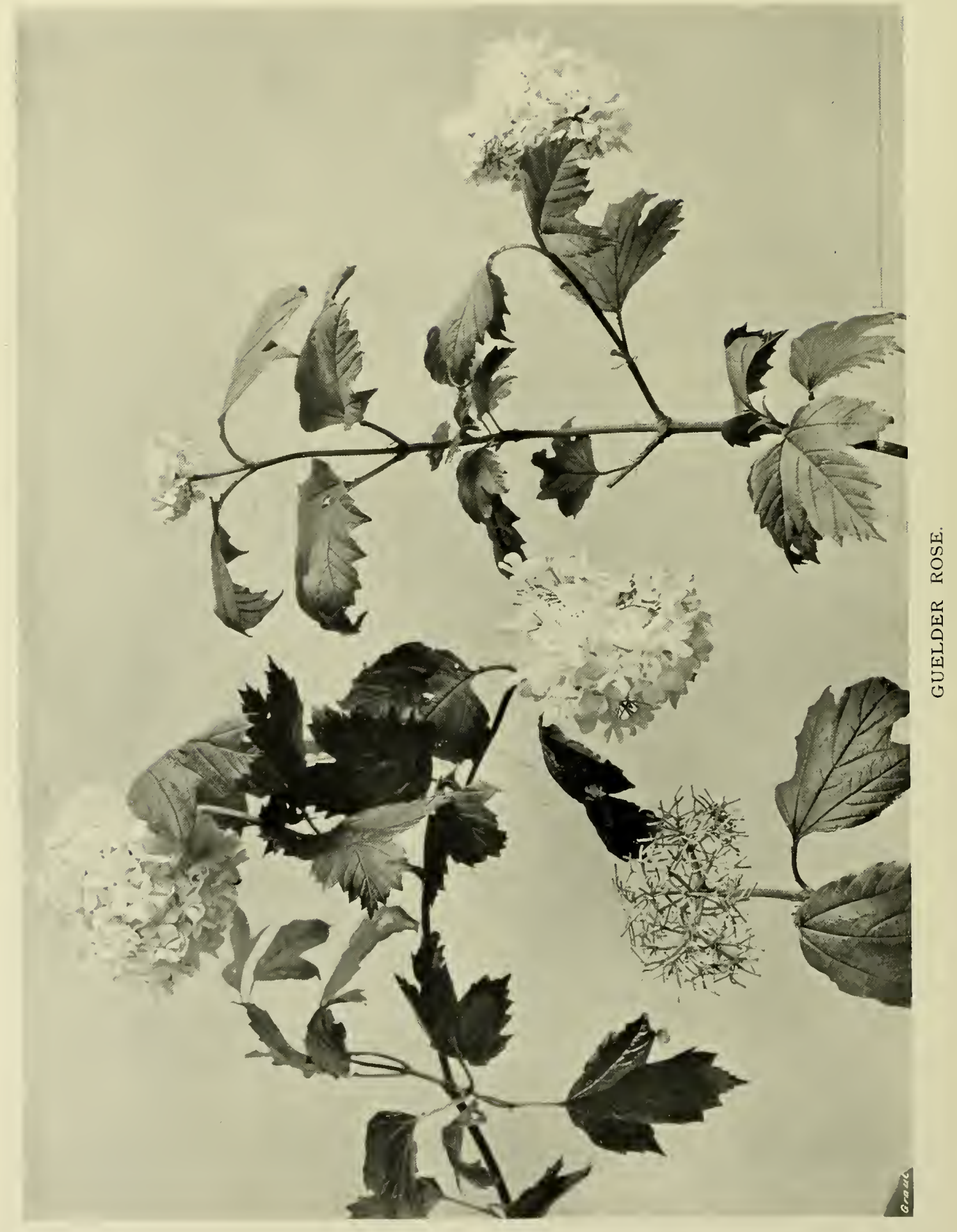


r9. GUELDER ROSE.

The Guelder Rose, Geldres Rose, Rose Elder, Whitsuntide Boss, or Snowball-tree, as it has been variously termed, is a freely-growing and beautiful tree, small in stature, but beautiful to look upon; whether in the spring, when loaded with its characteristic blossoms, or in autumn when the leaves take on their rich colours, and the wild variety is adorned with clusters of ruddy berries. Gerard seems to have known only the cultivated form, for he says " but in my garden there groweth not any fruit upon this tree, nor in any other place, for ought that I can understand." The leaves of this tree and their distribution, are very well worthy of study from the artist's point of view, and the structure of the flower is also of great interest. 
20. TULIP TREE, FLOWER.

Although the Tulip-tree came into Great Britain from its home in North America, only in the year I663, it was once a great favourite by reason of the beauty of its growth and flower. Some time ago, it is recorded that there were some fine trees in the suburbs of London, and especially in Fulham and Walham Green; but it is to be feared that they have for the most part disappeared. The tree flourishes in Norfolk, and has been cultivated so far north as Fifeshire. Its lily-shaped flowers have a curious arrangement of their six petals, three without and three within. In England trees rarely flower until they have attained a good age, but in warmer countries this is not the case. A fine specimen, when covered with the delicate mottled blossoms, is a very notable sight. It is a pity that it is not grown to a greater extent. 


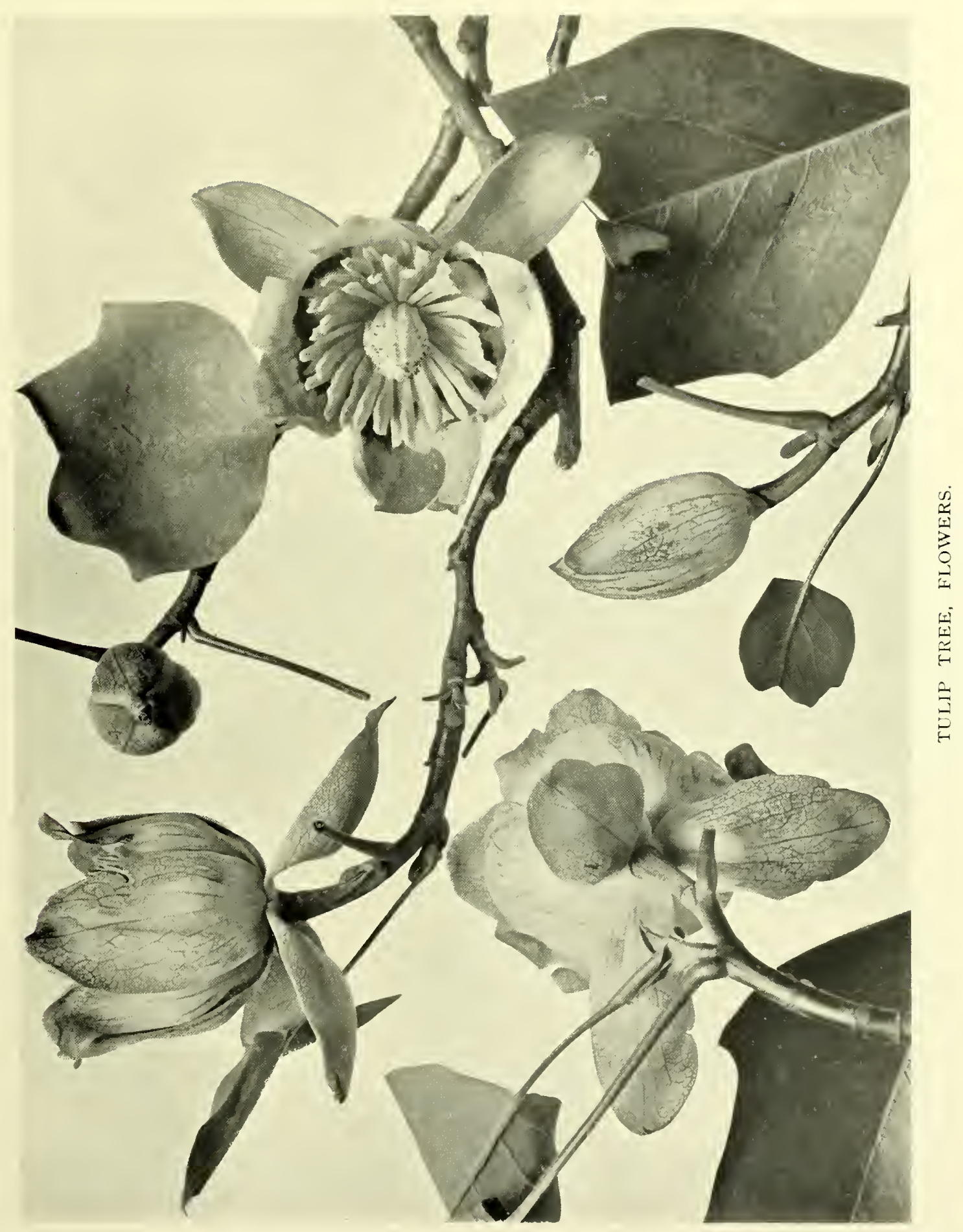






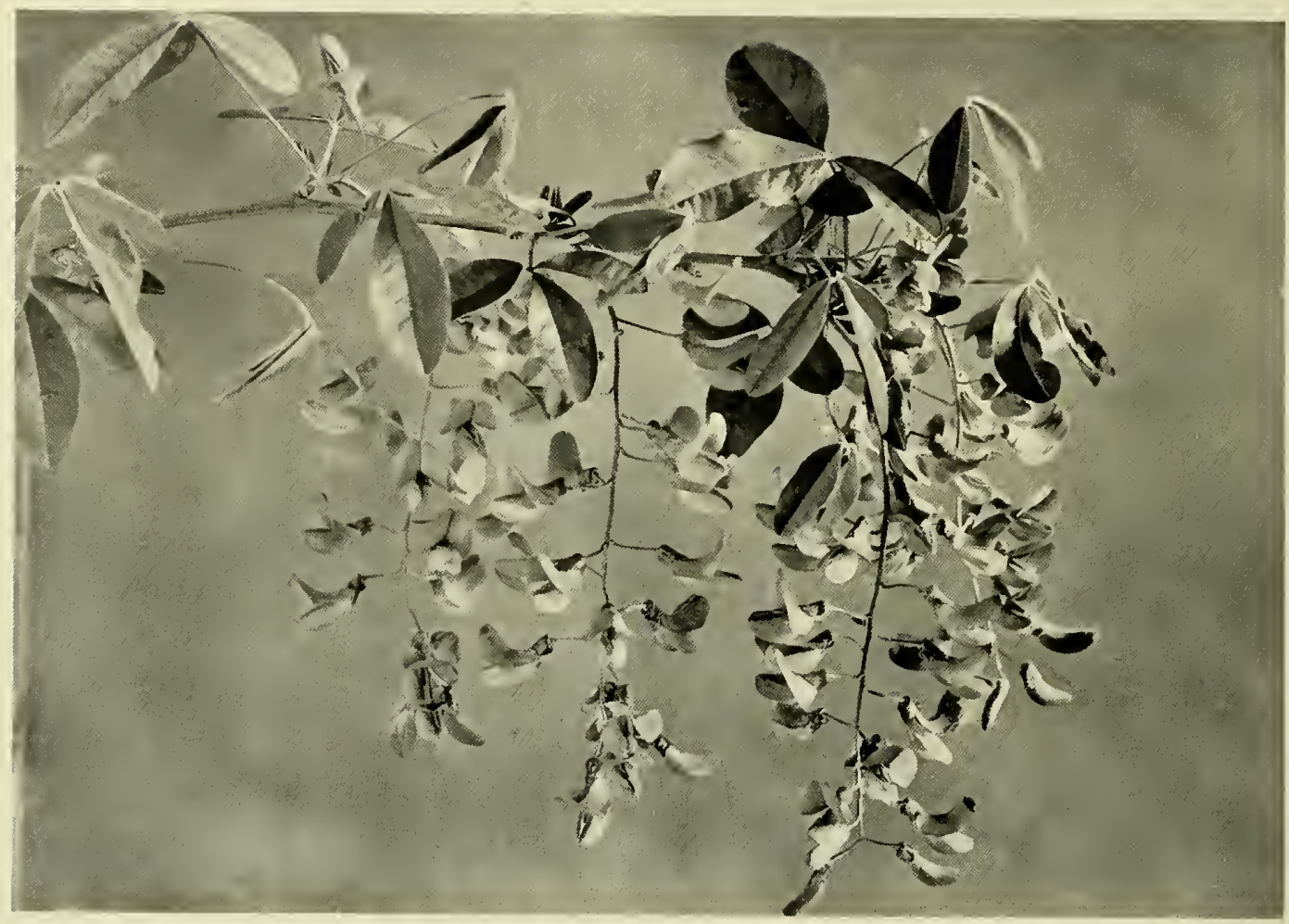

LABURNUM

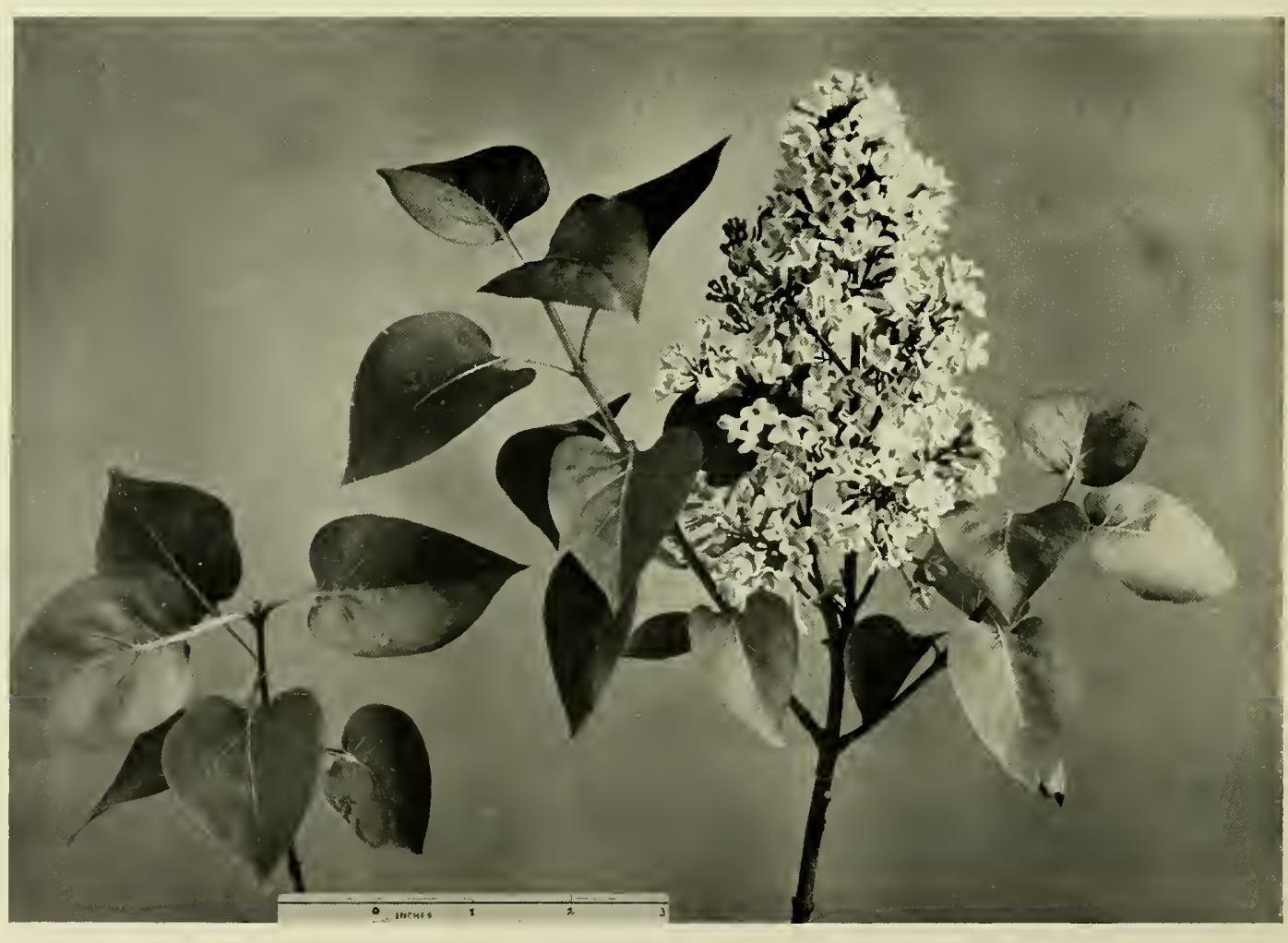

LILAC. 


\section{I. LABURNUM.}

The Laburnum, or, as children delight to call it, Golden Rain, although now so common, has not for long dwelt among us. It was certainly known on the Continent in the sixteenth century, and its wood then had the reputation of being the best for making bows. But one of the best varieties, at least, comes from North America, and was introduced into England by $\mathrm{Mr}$. Peter Collinson about the year I734. It does not seem to be mentioned by the writers of the older English Herbals. The student of plant-form will find it interesting to compare the blossom of laburnum with that of Wistaria, and the exercise should be prolific of suggestion as to the merits of each in decoration.

\section{LILAC.}

The Lilac is a shrub of Persian origin, and came into Europe during the sixteenth century, as did other Persian flowers, by way of Constantinople and Vienna. It was known to Gerard as the "blewe pipe flower," and he describes it as "very like the leaves of a poplar tree, among which come the flowers, of an exceeding fair blewe colour, compact of many small flowers, in the form of a bunch of grapes." As a matter of fact, the flowers, as we know them, vary from white to a rather deep crimson; and there are few more characteristic of the typical old English garden than the sweet-smelling " laylocks," which grow therein so freely and flower so bounteously. Its colours are characteristically Oriental. In the mass they are, perhaps, somewhat difficult to treat decoratively, but in detail they deserve the attention of designers, especially for small patterns. 


\section{HAWTHORN, FLOWERS.}

The Hawthorn or white-thorn has been associated with lore and legend for innumerable years. It is paired with the black-thorn, and, as a rule, represents good as opposed to the evil influences of the latter; also it is one of the mystic trees said to be sprung from lightning and consequently immune from the effects of it, and used as a charm accordingly. The Romans made their marriage torches of the white-thorn, and it has also been employed for wishing-rods. The Celtic races, especially in Ireland and Brittany, have a great veneration for old thorn bushes. They are the trysting-places of the fairies and no evil spirit will dare to approach them. The blossom of the hawthorn-May-must on no account be brought into a house during the month of the same name, or a death will occur before the end of the year. The winter-flowering variety is associated with the story of St. Joseph of Arimathea and the foundation of Glastonbury Abbey. And it is one of the plants of which the Crown of Thorns was made, as an old writer says"The Jews scorned Hym and maden Hym a croune of the branches of Albespyne, that is white thorn." Hawthorn blossom has long been a worthy favourite, in decoration, especially ceramics and needlework; but, as pointed out elsewhere, the so-called "hawthorn" of Chinese and Japanese artists is really a variety of prunus. 


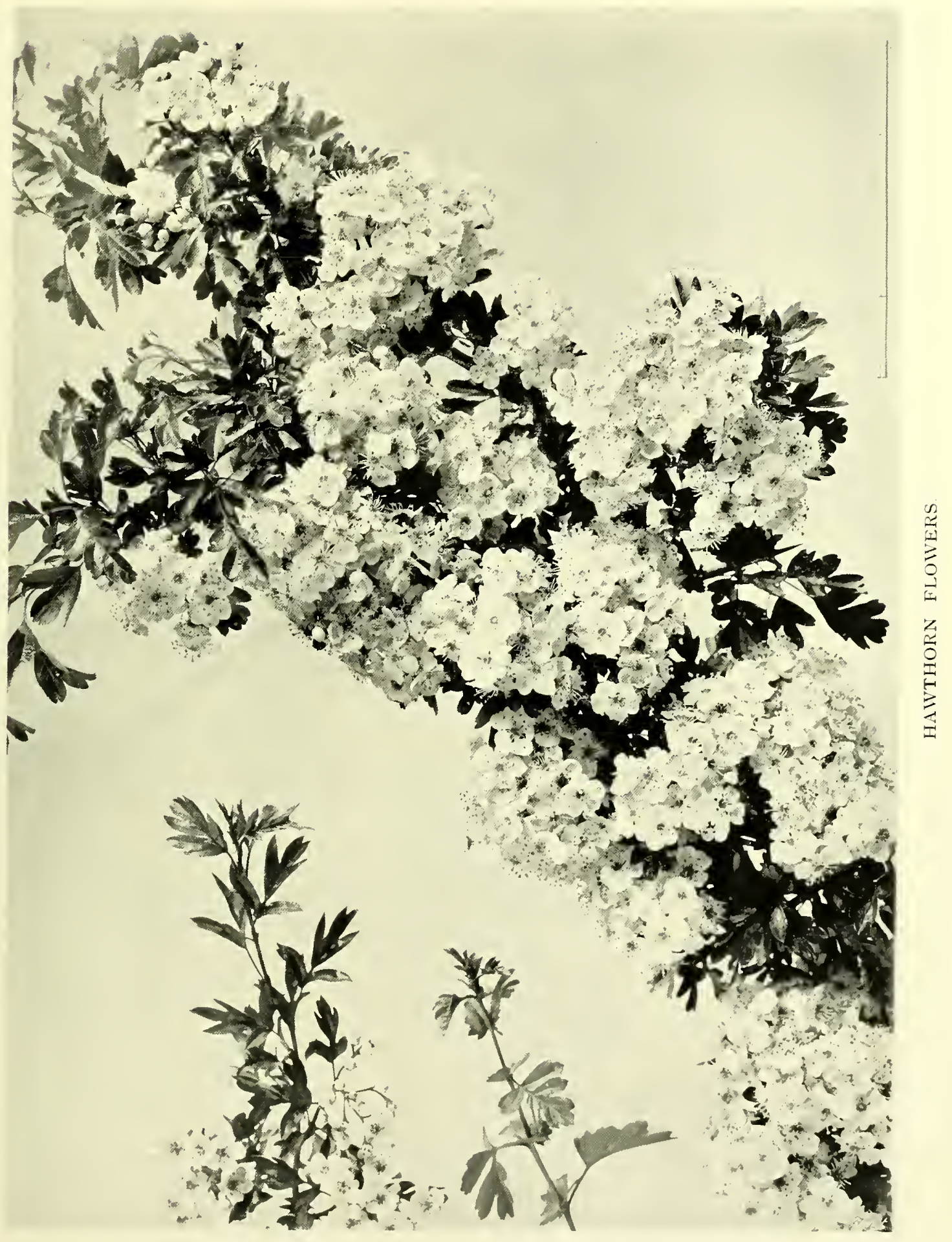




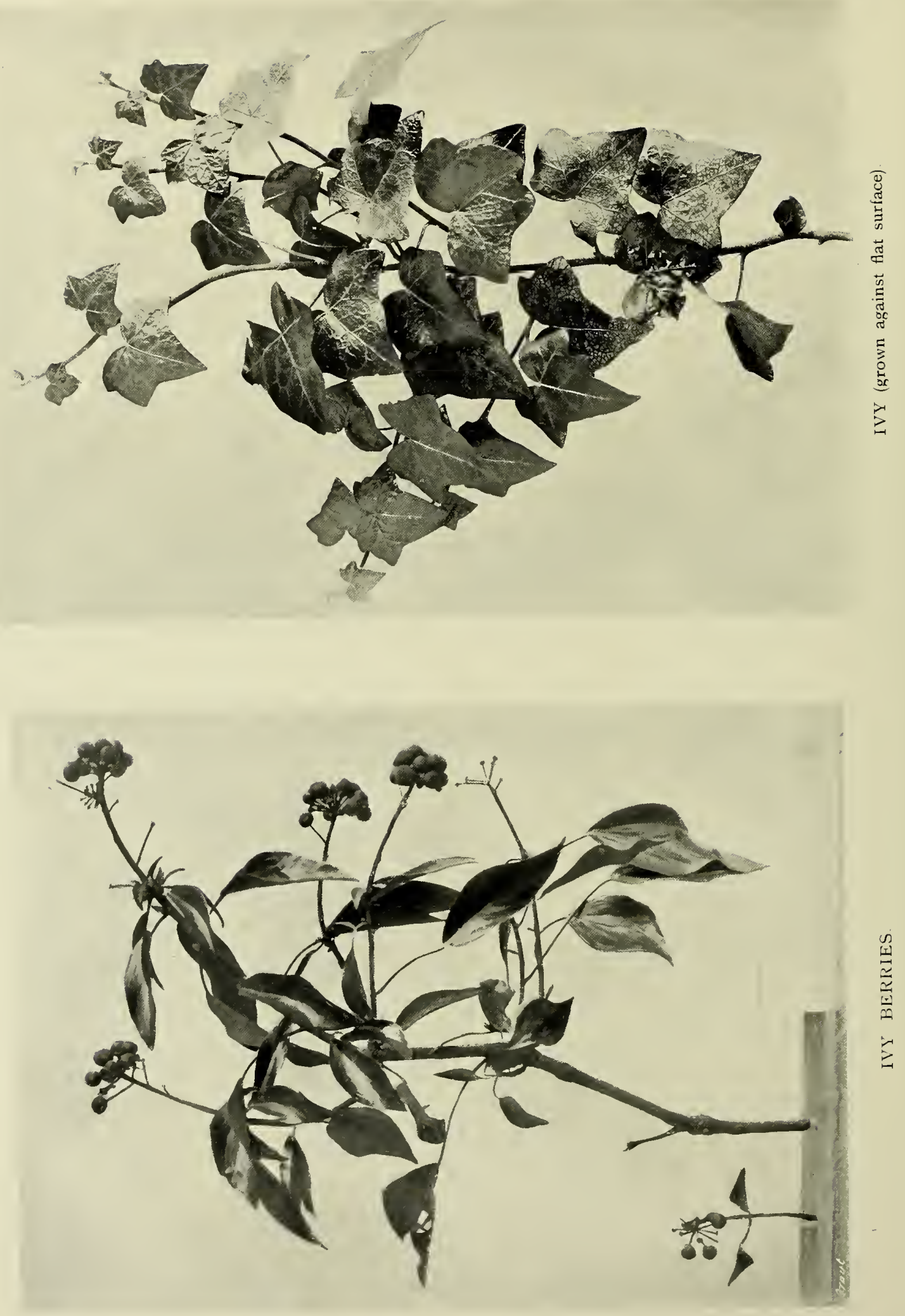
24, 25, 26. IVY, FOLIAGE, FLOWERS, AND BERRIES.

In classical mythology the ivy was associated with Bacchus, who, when an infant, was hidden from the anger of Juno beneath sprays of it, and was generally represented as crowned with ivy wreaths. It also played a part in the marriage ceremonies of the ancient Greeks, as a symbol of the binding nature of the tie ; and the crown of Apollo, as a poet, and consequently of other poets, was made thereof. The ivy leaf, as an ornament, was used on Greek (Ionic) vases after the middle of the sixth century B.c.; and, treated realistically, was a favourite decoration of later Roman and Italian ceramics and silver ware. It also was largely employed by Gothic sculptors, and, in short, has been one of the most popular and favourite subjects of decorative artists of many ages. In the growth of its foliage the ivy displays an astonishing variety of form, ranging from an unbroken outline, to three, five or seven-pointed leaves, the variation being, largely, it would seem, ruled by the situation in which it is found. Charles de Guise, Cardinal of Lorraine, had for his device a pyramid clad with ivy, as an emblem of permanence, with the motto Te stante virebo. The old notion that ivy sucked the nourishment out of the trees on which it hung does not appear to be justified, though it has furnished poets with many beautiful similes.

Chaucer, in the Nun's Priest's Tale, refers to it as

"Herb ivy, growing in our yard, that merry is." 


\section{SYCAMORE LEAF.}

The sycamore tree has a beautifully shaped and modelled leaf, which has been and still may be of great service to designers. The tree, although now so common in this country, is not indigenous; and, although it is said to have been introduced by the Crusaders, was rare enough in Gerard's time to be referred to by him as "a stranger in England." He calls it the great maple; and by a wrong analogy it has also been termed the false plane. It is mentioned by Chaucer in The Floure and the Leafe; and was generally believed to have been the tree into which Zaccheus climbed, although this was more probably the Black Mulberry (gr. sycominos) or a species of fig (Ficus sycomorus, in Hebrew Shikmin or Shikmoth). The growth of the leaf, which occurs in pairs, and the development of the bud, in which it is rolled fan-wise, as well as the fruit, should offer valuable suggestions to designers. 


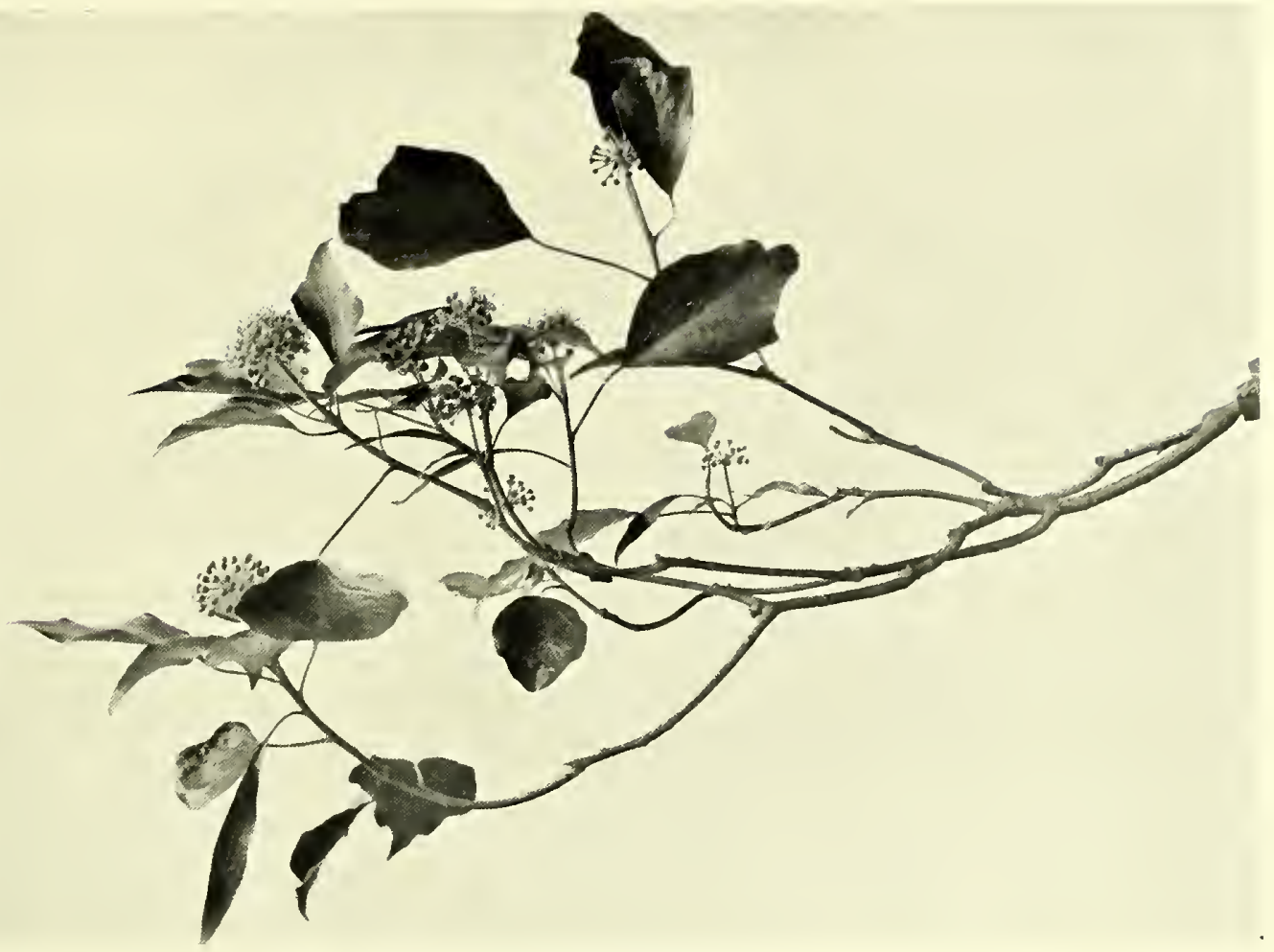

IVY FLOWERS.

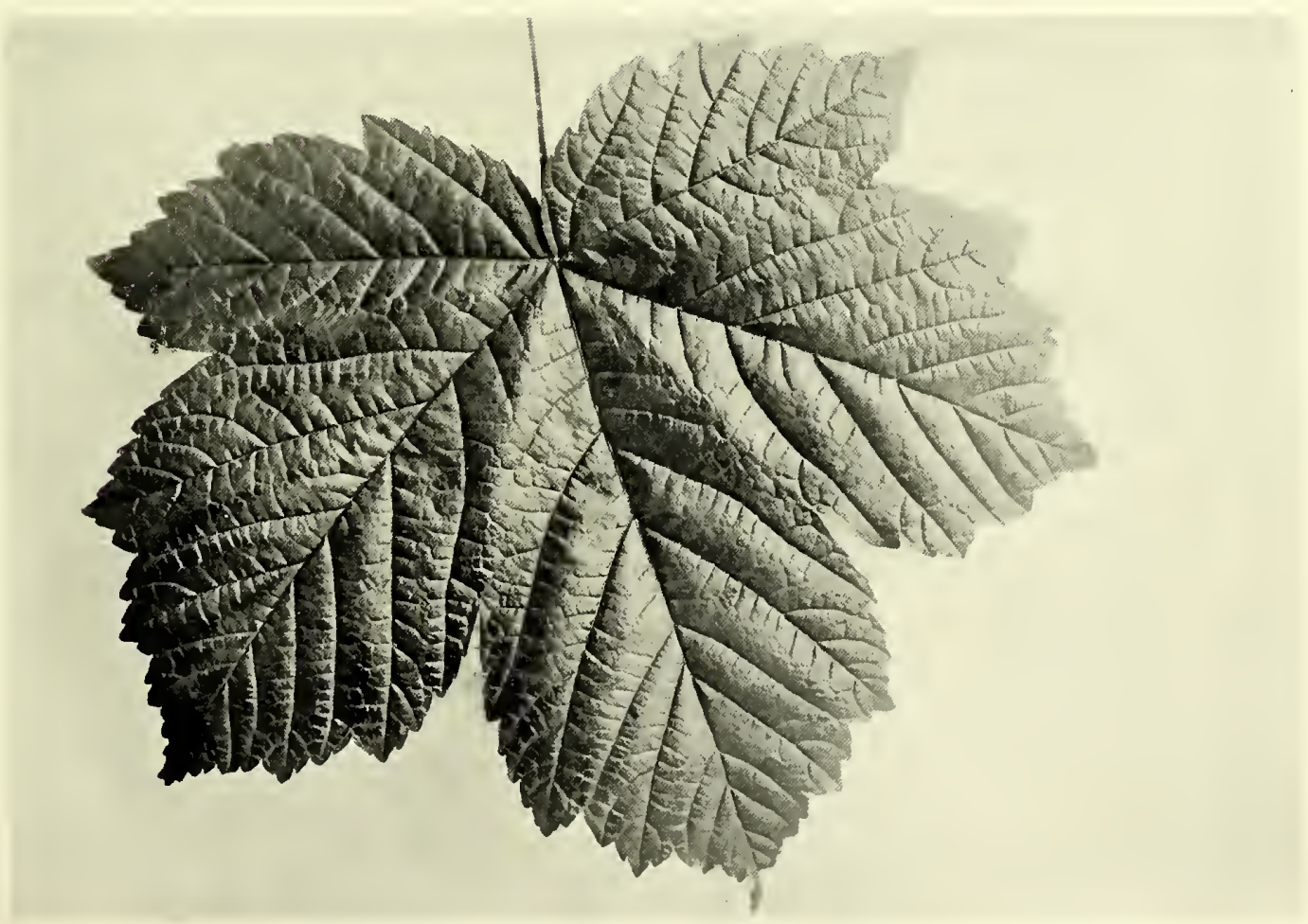

SYCAMORE LEAF. 



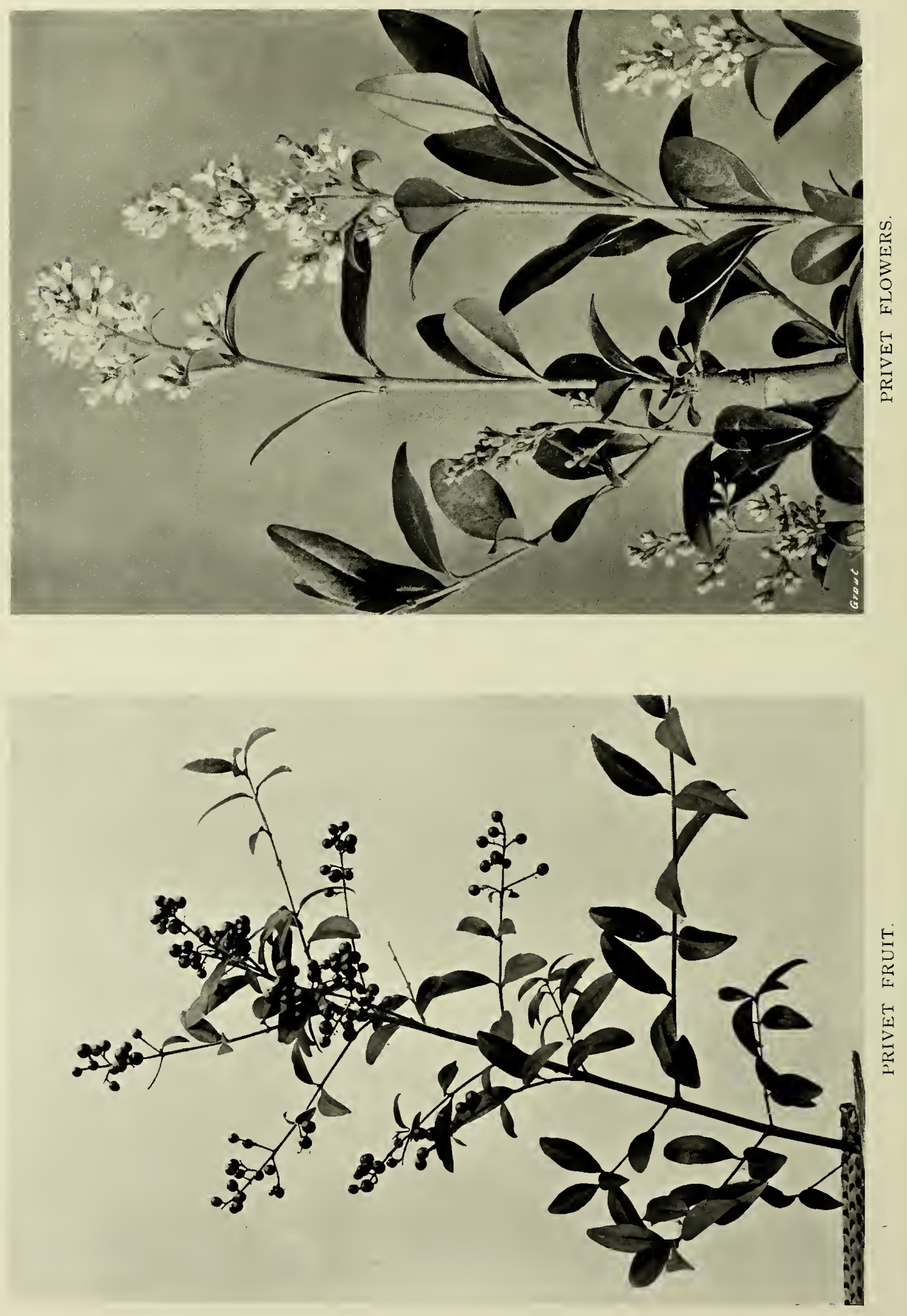


\section{8, 29. PRIVET, FLOWERS AND FRUIT.}

When it is allowed to grow freely, and to flower, the privet produces long branches, of which the leaves in pairs, the blossom and the rich clusters of shining berries which follow, are of considerable grace and beauty. The shrub grows, in a wild state, throughout Europe and the West of Asia. It is practically evergreen; but seems to have acquired no legendary associations. The origin of its name is unknown, but it was formerly called prim, print and primprint, and some of the old writers seem to have arrived at a curious and inexplicable confusion in this respect, for the plant they called Ligustrum, or privet, says Mr. F. E. Hulme, was what we now know as the primrose! 


\section{0, 3I, 32, 33. WILD ROSE.}

Of roses in general many a book has been written, and of the wild varieties of the Queen of Flowers much more might be said than can be compressed into a brief note. But these latter have always had a special charm for the poets, whether of Persia, the natural home of the rose, or Britain, the country of its adoption. The Dog Rose, with its pink blossoms, and the Trailing Rose with its pure white are old favourites, too well known to need description. They have been used, time out of mind, by painters and decorative artists, and ballads and folk-tales are filled with allusions to them. That beautiful old name, Eglantyne or Eglantere, seems to have belonged to the Briar Rose. The Southwark Herbal says "Eglentyne;-Bedegart is an herbe that groweth in playnes and harde grounde, and hath a fatte lefe jagged and cloven . . . and spredeth on the erthe whyle it is yonge and hath a white thorne very sharpe in ye myddes, and after it groweth to the heyght of a cubyte and no more. It hath many lytel pryckes and a reed floure. It comforteth the stomake and ceaseth long fevers." The rose is a frequent element in ornament, from the I5th century onwards. By common consent it is accepted as the flower of England, and although it is not borne on the national arms, it has been used as a royal device since the time of Henry VII. It was also adopted by the Orsini family, by Cornaro, Bishop of Padua, and (half-opened) by Louise de la Valliére. In the language of flowers it has always symbolised love. Hips, also, are old in story. The Northern saw has it that

"Many hips and haws,

Many frosts and snaws."

They were formerly a favourite conserve, though one imagines that as an article of food they are now left entirely to the birds. 


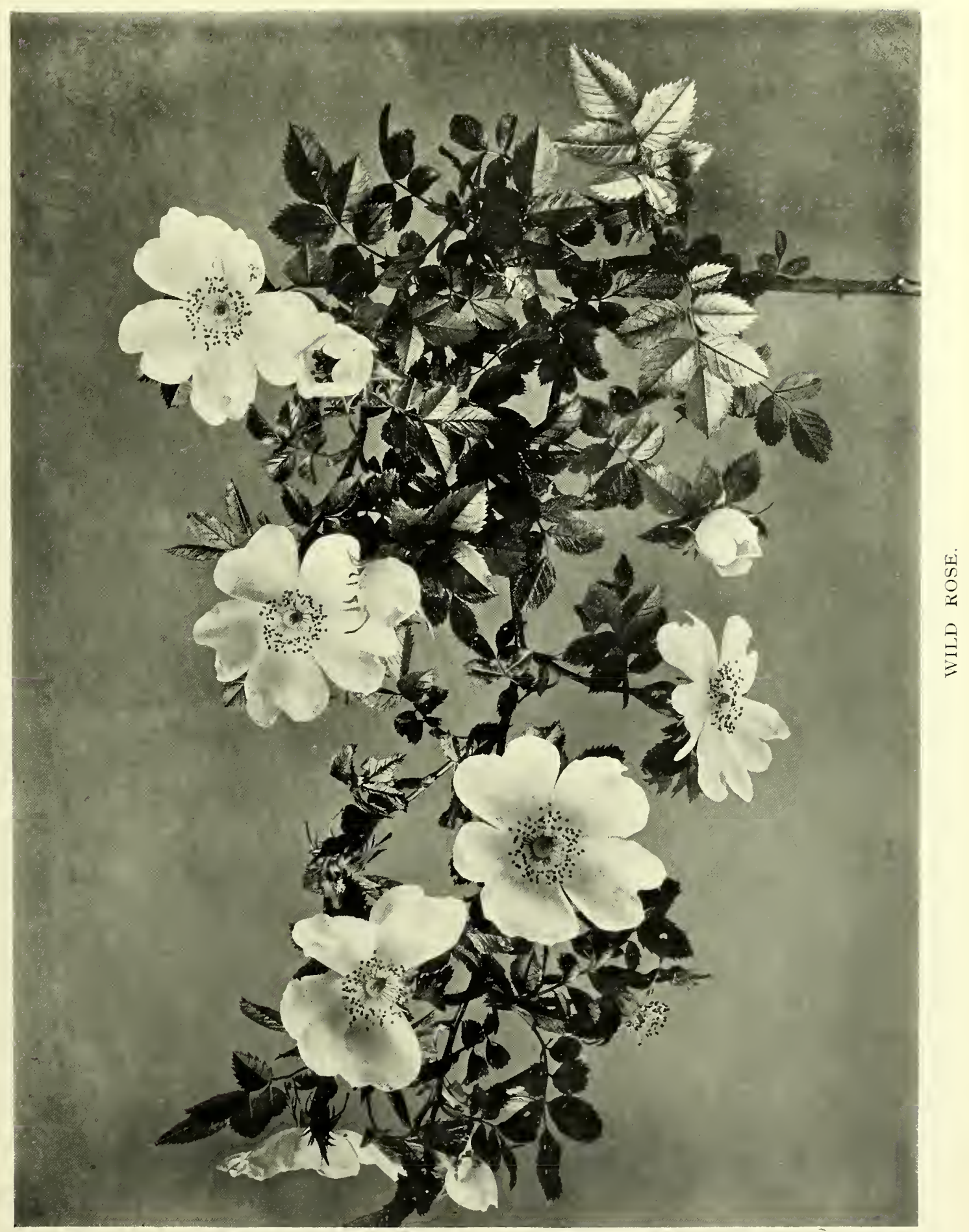





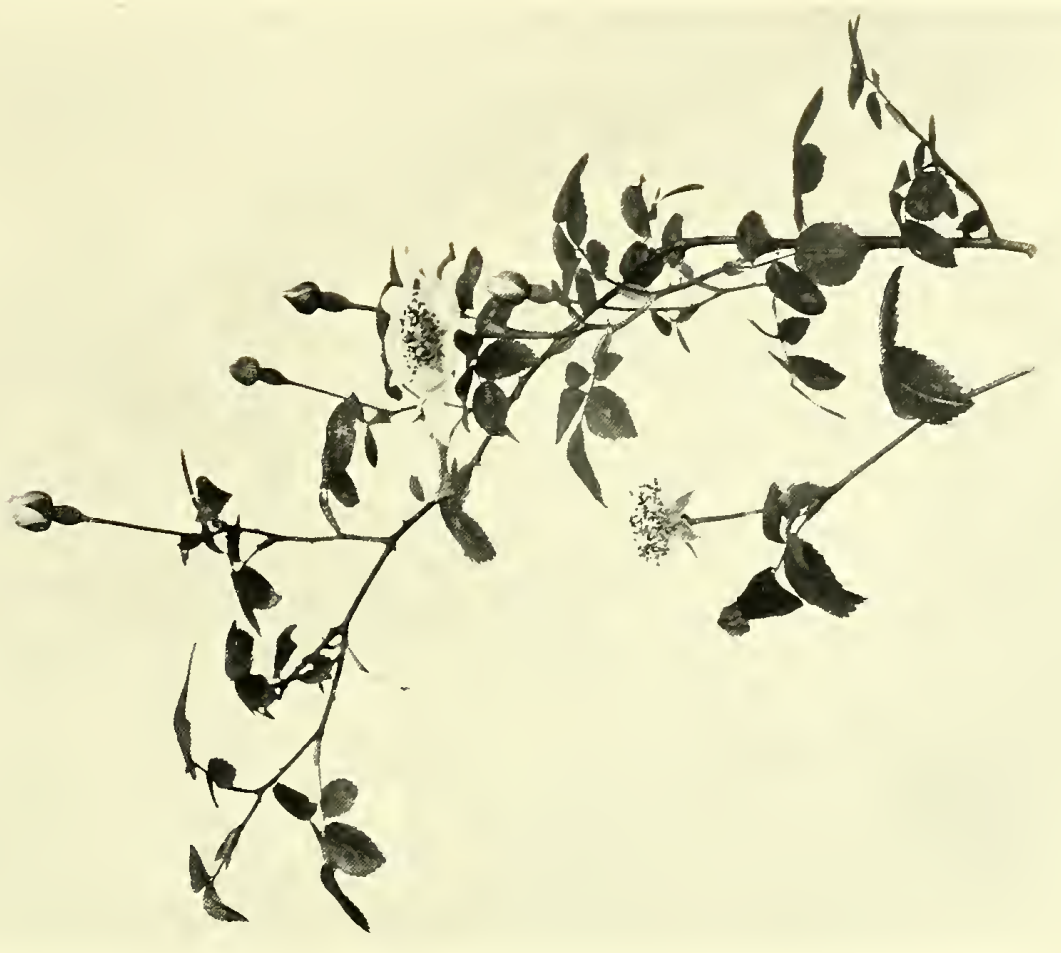

1
0
2
0
0
0
0
$\vdots$
$\vdots$
3
0
0

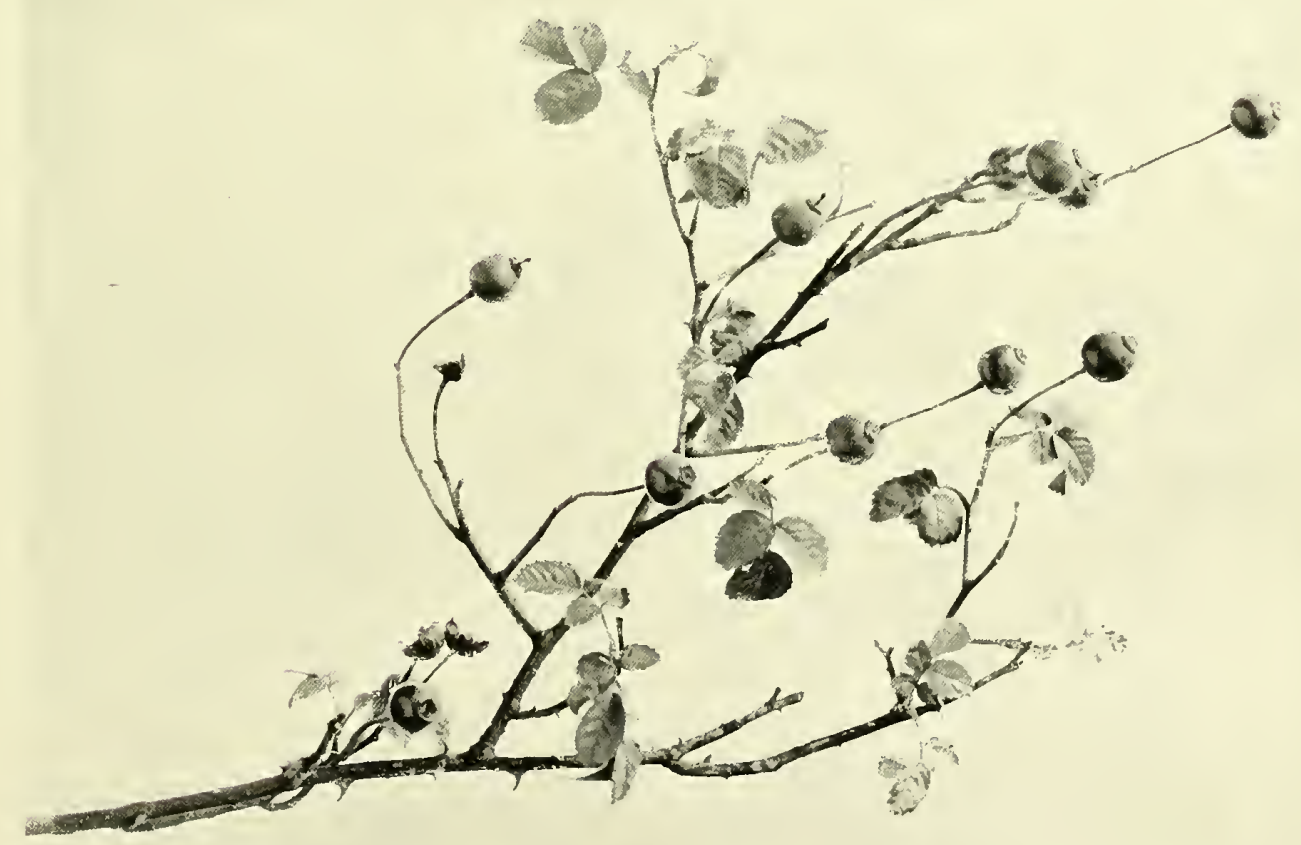

HIPS OF TRAILING DOG ROSE. 



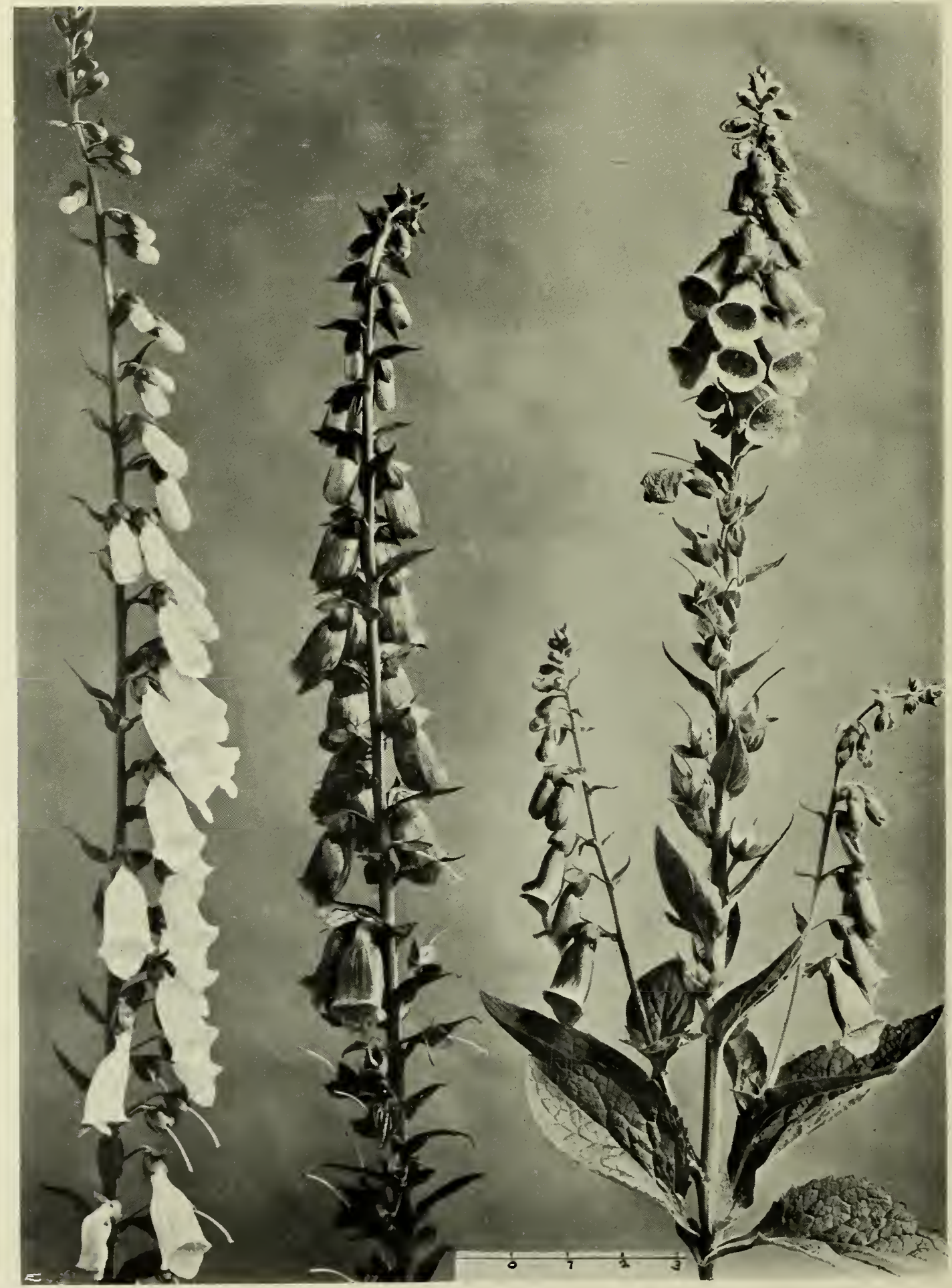

IOXCiLOVES 


\section{FOXGLOVE.}

The Foxglove is one of the most graceful and decorative of wild flowers. It is capable of an astonishing variety of gradation of its few colours, and there are not many of its fellows which can produce an effect of such splendour as the serried ranks of purple spikes to be seen in July, along the sides of west-country lanes. The characteristic form of its single blooms has gained it also the name of Thimble-wort in England, and Gant de Notre Dame-Our Lady's Glove, in France. It was at one time famous for its medicinal properties, and has been termed the emblem of youth; though, says one authority, "others, in allusion to its flowers, which offer some resemblance both to the cap and the bells, have made it the emblem of folly." 


\section{LUPIN.}

This flower, whose spikes of blossom and leaves have so fine a decorative effect, was esteemed by the Romans chiefly as a food. It was supposed to brighten the mind and quicken the imagination; and the painter Protogenes, of Rhodes, is said, for this reason, to have lived exclusively on lupin and water for the space of seven years, while engaged on one of his masterpieces. The digitate leaf of the Lupin has the curious quality of folding itself on its stalk at night ; when displayed it is admirable in form and should be of great value to the designer. 


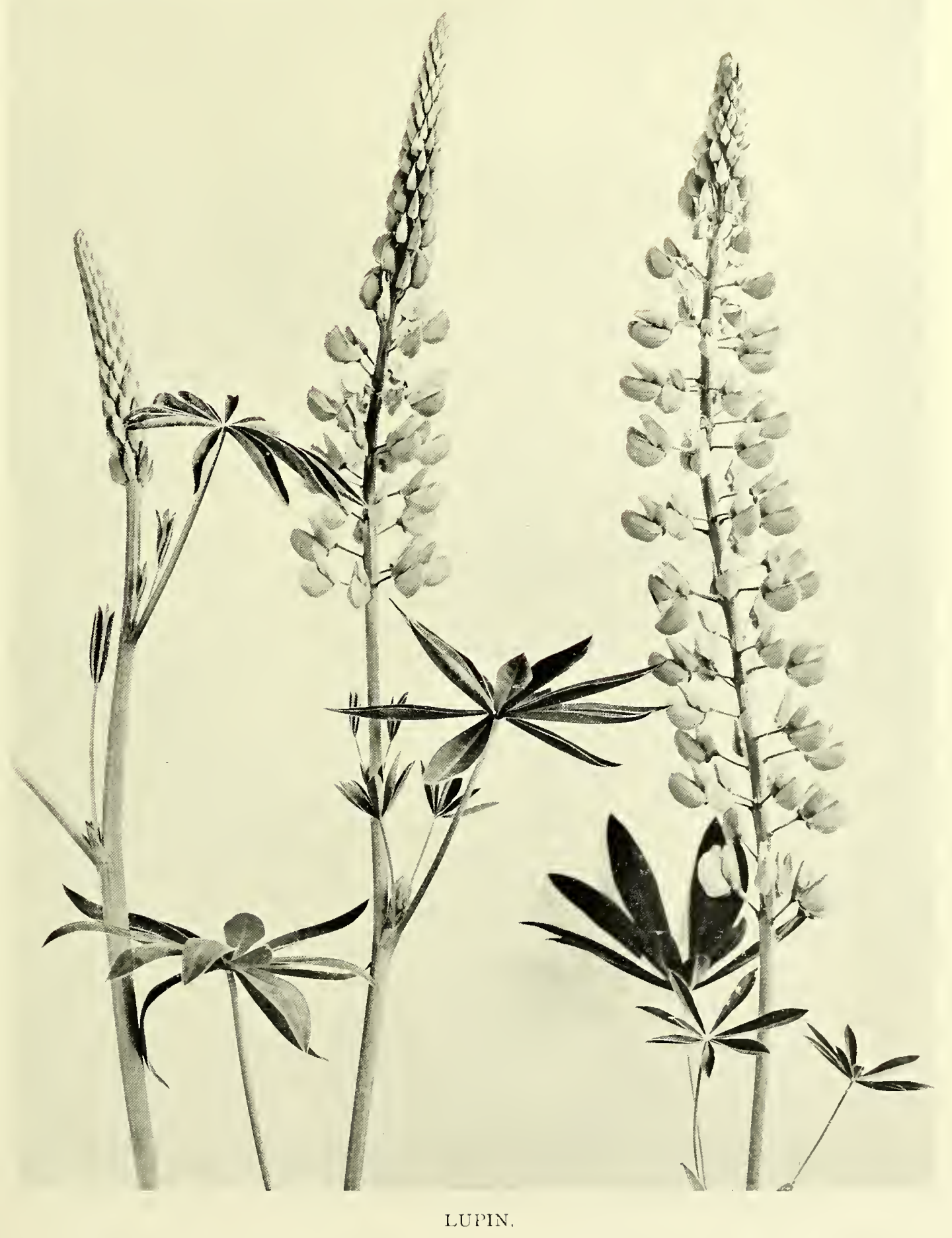





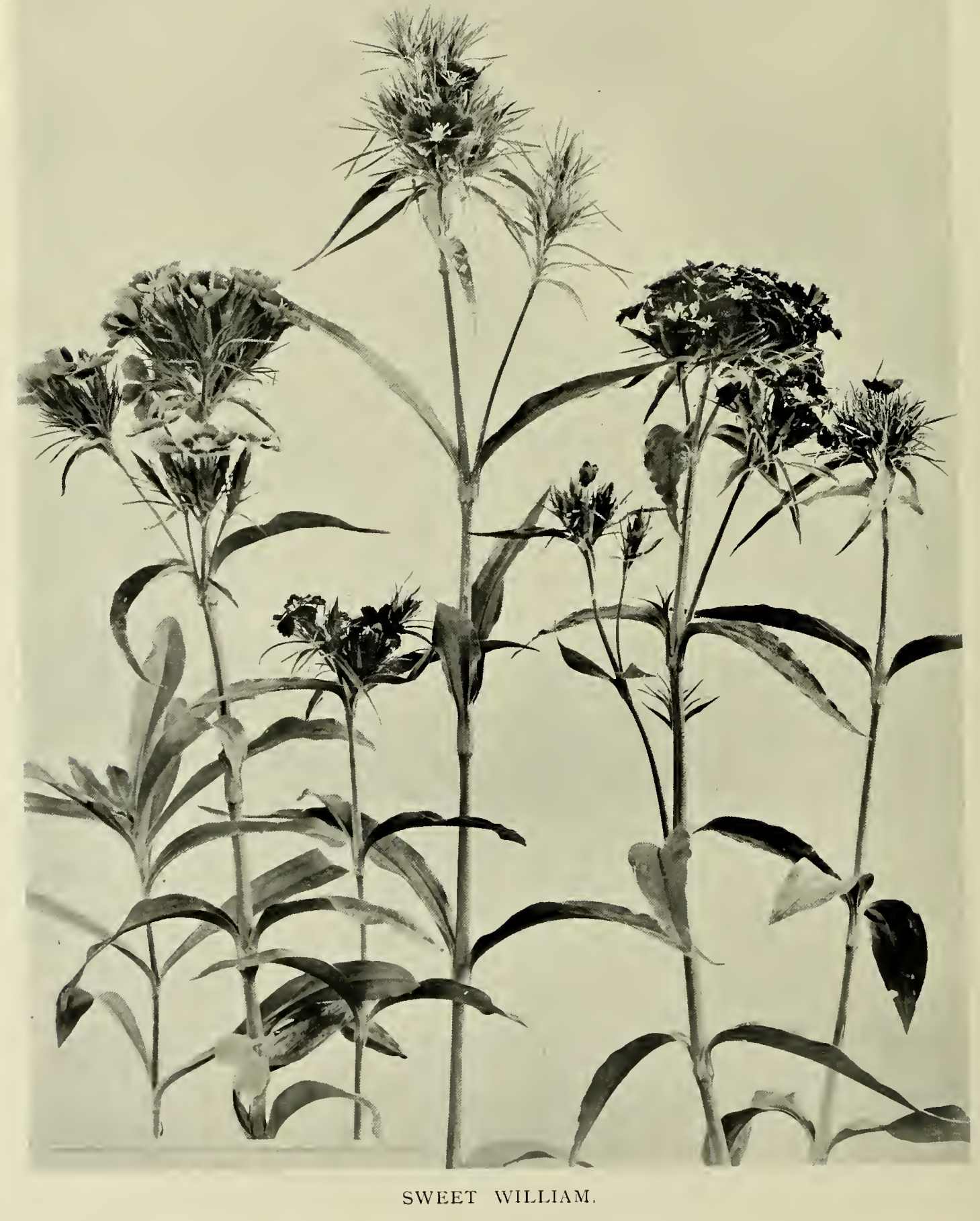




\section{SWEET WILLIAM.}

The Sweet William is generally believed to be a native of Germany, whence it has spread all over Europe; though there is some reason to think that it is also indigenous to Normandy and parts of Flanders. It is first mentioned in the Herbal of Dodoneus; but Gerard refers to it as common in gardens in his time, and gives it the name by which it is best known-perhaps, one writer wildly conjectures-out of compliment to Shakespeare. Other old names are "London Tuftes" and "Bearded Pink." The Sweet William is symbolic of diplomacy. It has been little used in the arts. 
37, 38. POPPIES.

Poppies, by reason of their physical properties, have always symbolised sleep, and secondarily, the Sleep of Death. Their name is as old as Anglo-Saxon times; and the flower itself was well known to the Romans. One of its titles was Corn Rose, and, in the rites of Ceres, garlands of poppies and barley or bearded wheat were used. There is, in the Louvre, a statue of that goddess holding poppies and corn in her hand, and braided in her hair; and the flower occurs on other sculptures. The poppy is the emblem of Consolation. The Oriental poppy was discovered in Armenia, by Tournefort, and sent to Paris, whence it spread all over Europe. It was introduced into England about 1716 . The white opium poppy has been cultivated successfully in England for the sake of the drug; and in I82I sixty pounds of solid opium were obtained from a plot of about $4 \frac{1}{2}$ acres, in Buckinghamshire. 

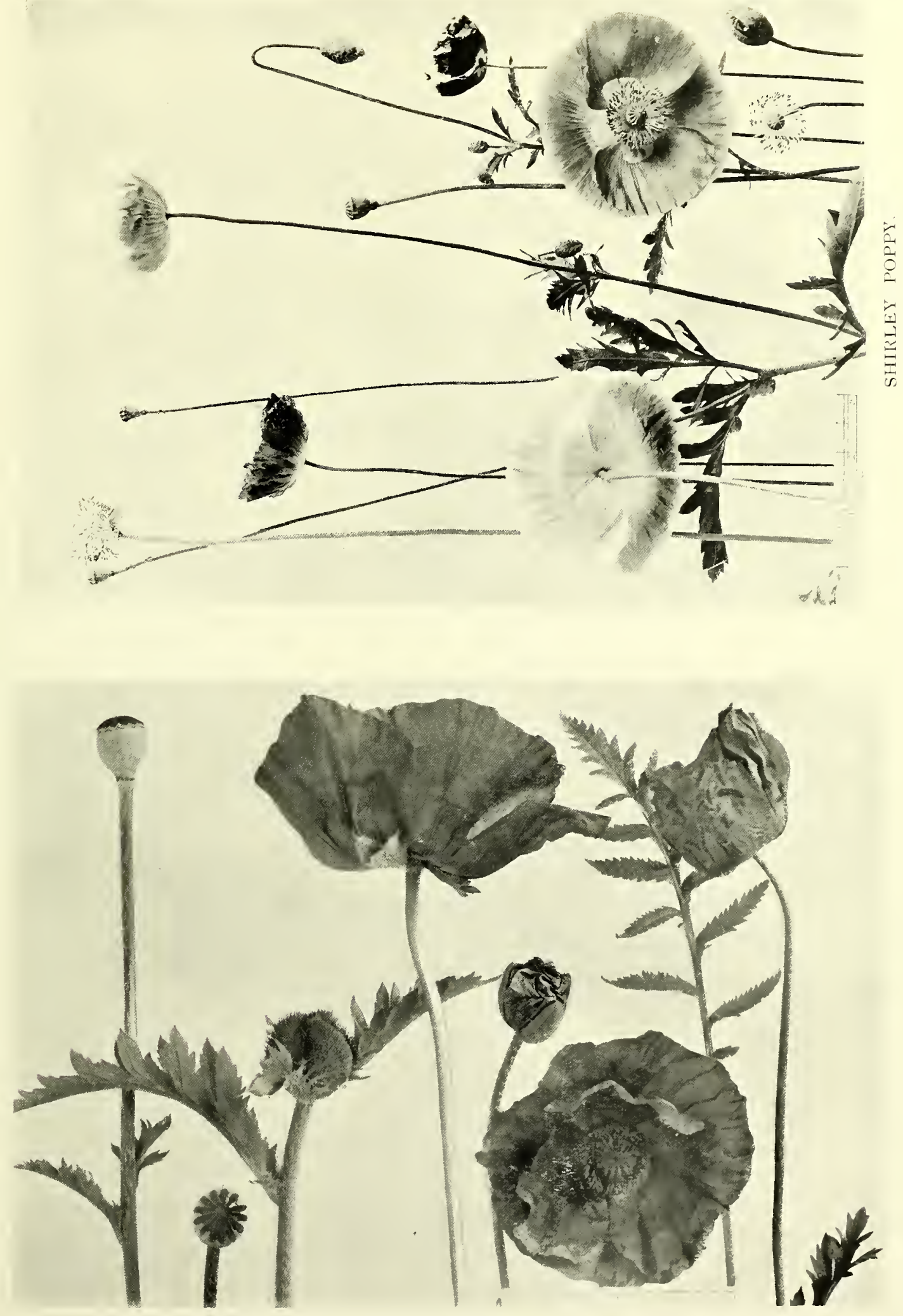

ORIENTAL POPPY. 



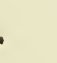



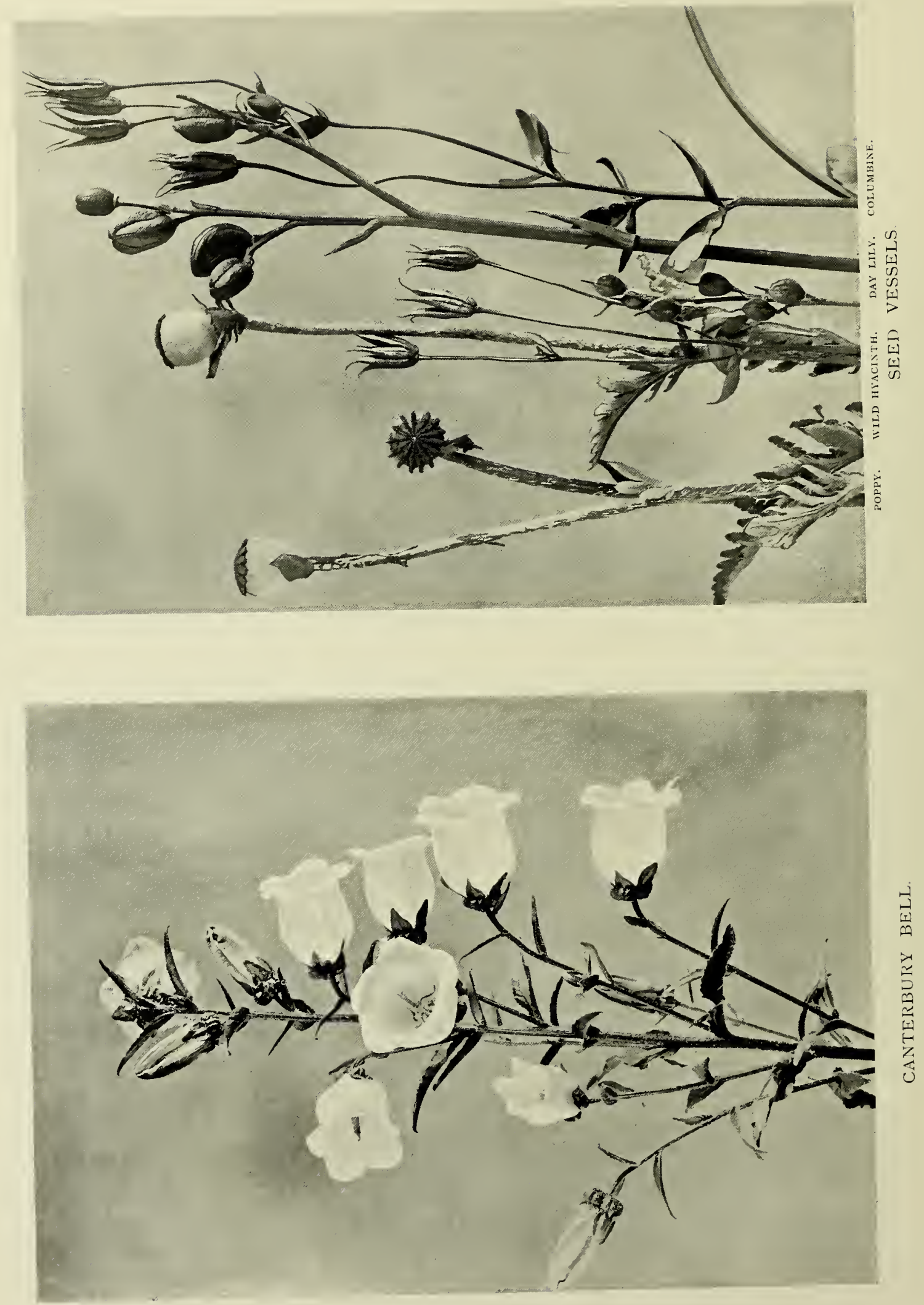


\section{SEFD VESSELS.}

The study of seed-vessels from the point of view of the designer has largely been neglected, with the exception of that of the poppy, which for a long while has held a recognised place in schools of art. Speaking generally, there is hardly one which does not display beauties of form and structure, in the highest degree educational, and the group here illustrated is given as a suggestion only, to be amplified to any extent the student may desire. The seed-vessels of the wild Hyacinth and Columbine are especially worthy of attention.

\section{CANTERBURY BELL.}

The Canterbury-bell, one of the best known of the Campanulas, is not a native of this country; though it has long been an inhabitant thereof. Gerard notes that "it do growe very plentifully in the lowe woods and hedgerowes of Kent," and it can still be found there. He calls it also "Haske woort" and "Throte woort," and it was once thought to furnish an excellent remedy for sore throats. One of the French names for it is Gant de Notre Dame-Our Lady's Glove; a term it shares with the Foxglove. 


\section{I, 42, 43. PINKS AND CARNATIONS.}

The white pink is, says an old writer, "the emblem of lively and pure affection." According to Pliny, it was unknown to the Romans until discovered in the north of Spain, during the conquest of the Cantabri. It was well-established in England, by the sixteenth century, and is described both by Turner and by Gerard, the latter of whom calls it the "Wild Gilloflower." This blossom was a great favourite with the Northern French and Flemish illuminators, who frequently introduced it, very accurately drawn, into the borders of Horæ, Missals and other devotional books, during the latter part of the 15 th and first years of the 16th centuries. It also occurs frequently in English work of the same period, and has since been of great service to designers, particularly as a powdering. The red pink is symbolical of talent; the China or Indian pink, brought to Paris by missionaries, about the year I705, of aversion, illogically enough.

The Carnation is believed to have been cultivated from a small kind of red clove pink, and under the name of the Clove Gilloflower was known in England, at least as early as the reign of King Edward III., and was used to spice ales.

"Ther springen herbes grete and smale,

The licoris and the setewale

And many a clove gilofre

. . . to put in ale

Whether it be moist or stale."

This flower is called by Spencer "Coronations," perhaps because they were much used in such ceremonies; and Carnation is thought to be derived therefrom. Although 4I varieties were known in England in the reign of Charles I., the flower was nearly lost during the succeeding Civil Wars, and afterwards was renewed from Holland. The gillyflower or pink is occasionally used in heraldry, as, for instance, in the arms of Livingstone, Argent, 3 gillyflowers gules. 

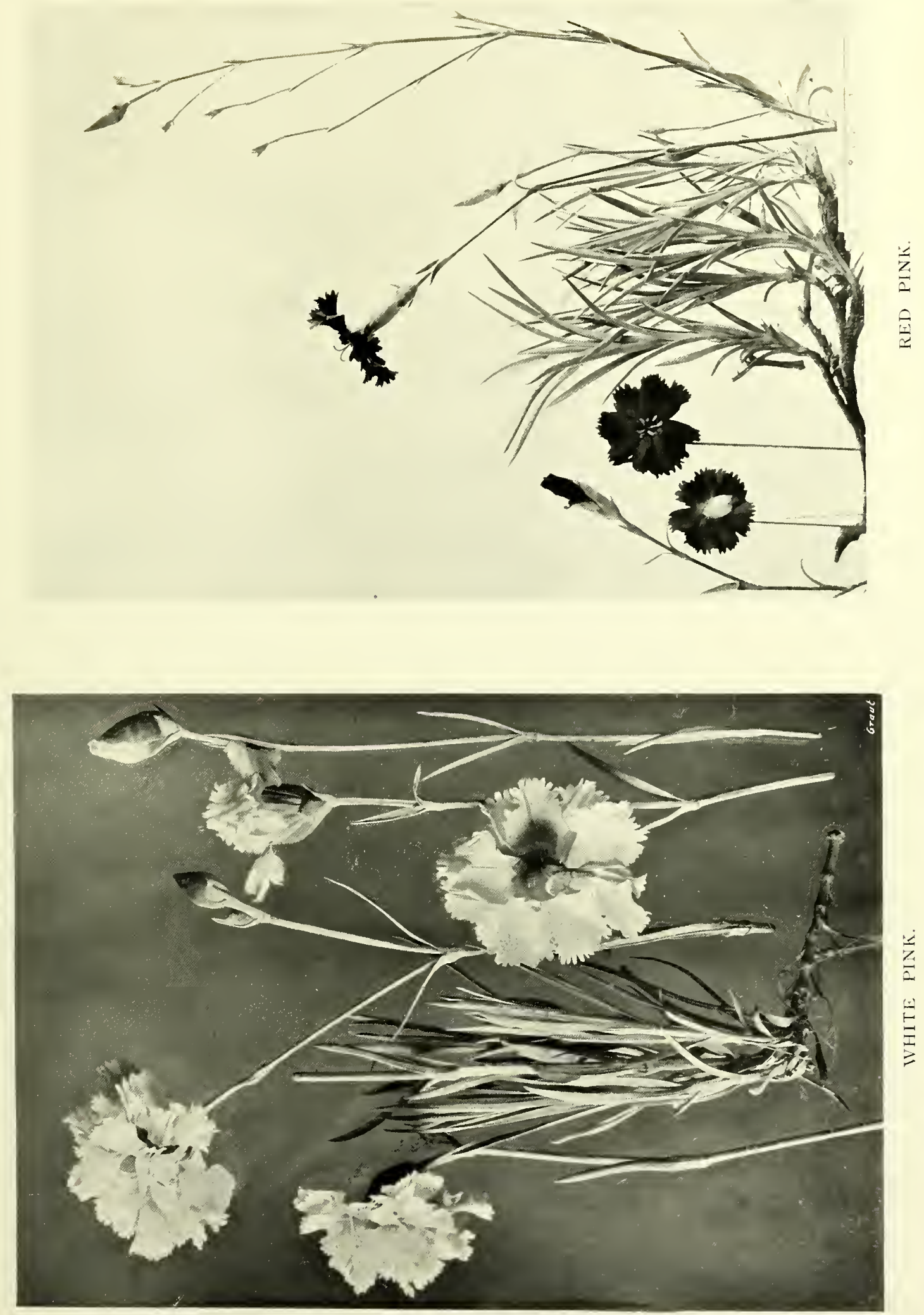

3
3
3
3
3
3 


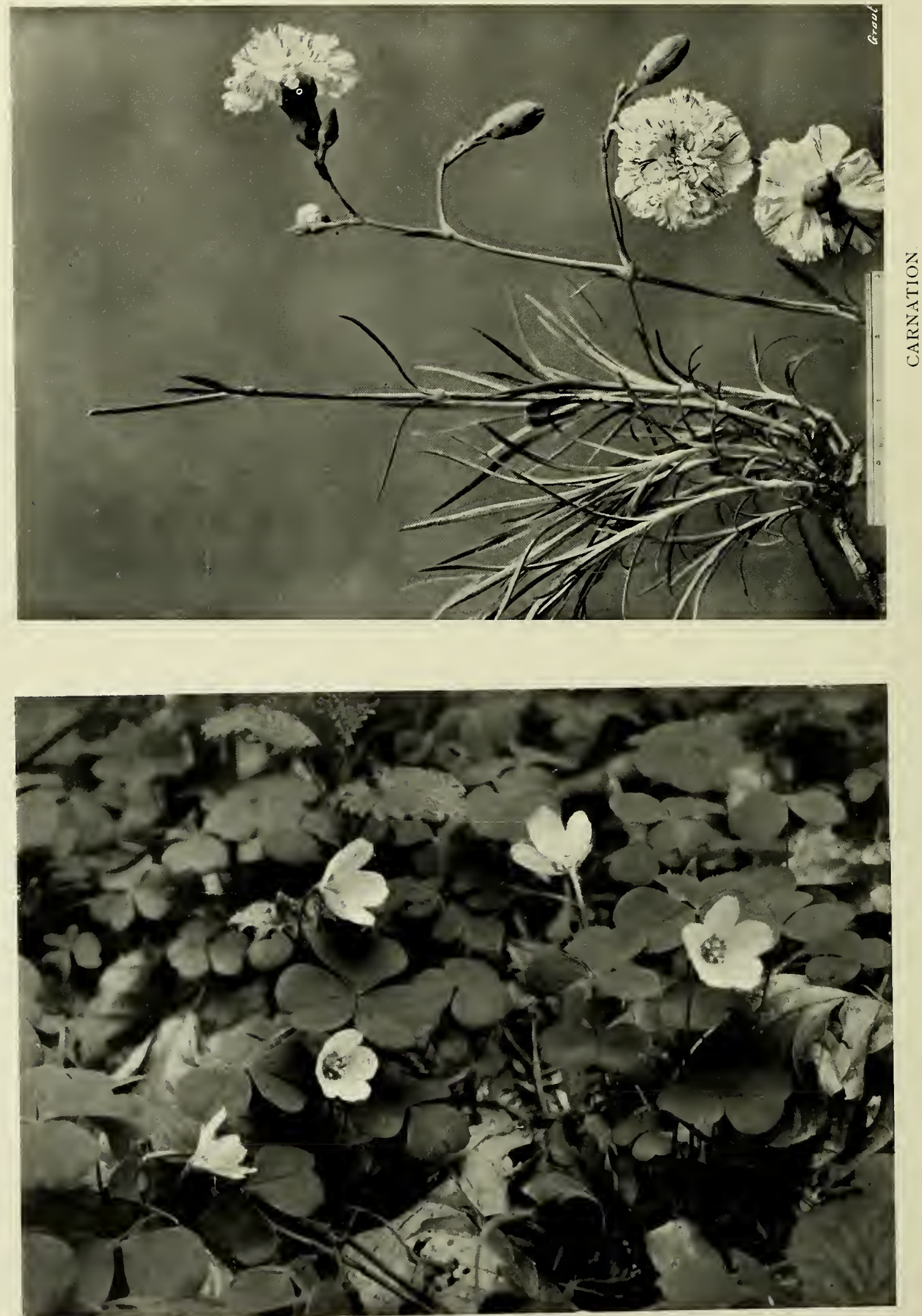

WOOD SORREL. 
44. WOOD SORREL.

The Wood Sorrel belongs to a family called by the old Herbalists Oxalis, on account of its acid taste. Parkinson names it Wood Sower, Stable-wort, Sorrel Dabois and "Cuckow-wede," the latter, says he, "eyther because the cuckowes delight to feed thereon, or that it beginneth to blossome when the cuckow beginneth to utter her voyce; it is called by the Apothecaries Alleluja, because about that time it is in flower when Alleluja in antient times was wont to be sung in the churches." The illustration here given represents this dainty plant in its natural surroundings, and may serve as a hint of the possibilities of finding, in Nature, not only details useful for ornament, but more than a bare suggestion of how they may be used in the composition of a pattern. The exquisite trefoil-shaped foliage, and simple but graceful flower will well repay the closest examination. 


\section{CHRYSANTHEMUM.}

Although some varieties of the Chrysanthemum are natives of Europe, the flower as we know it came from China, and, until the opening of Japan had familiarized us with the wonderful cultivation of it in that country, it stood in our botanical books as the Chinese Chrysanthemum. Indeed, our knowledge of the love of the Chinese for it and of the many uses to which they put it in the arts, has been quite overshadowed by its Japanese fame, and the splendid treatment of it by the cratfsmen and artists of the latter country, of which it is the national flower. The Chinese Chrysanthemum was introduced into England by Miller in 1764 , who installed it in the Apothecaries' Garden at Chelsea. It seems, however, to have been lost, and was not reintroduced until I795, from stock of a purple variety brought to Marseilles by a French merchant, Blanchard, in I789. It began to obtain popular favour about 1820 , and in 1829 about 30 varieties were known to British gardeners. 


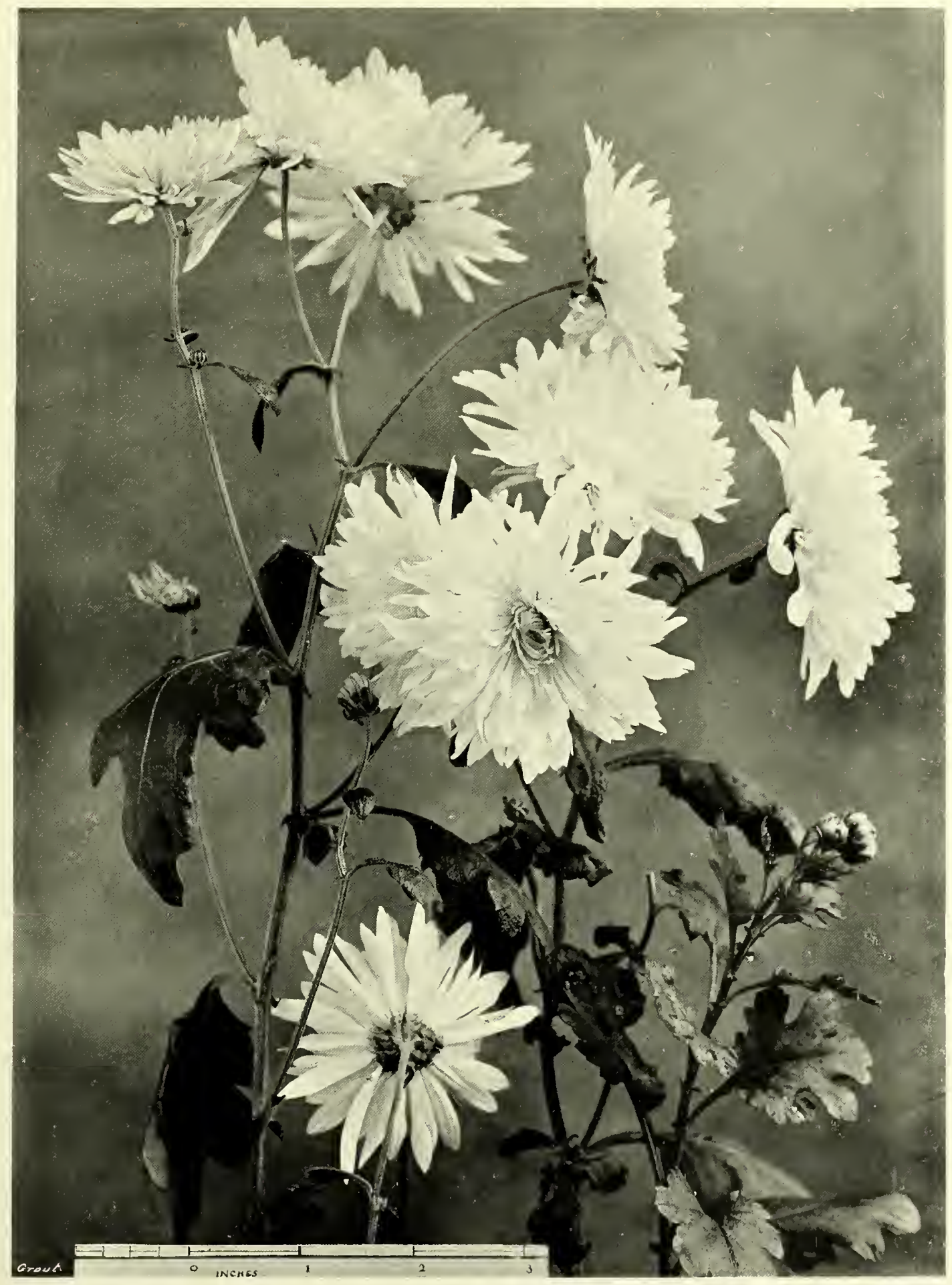

CHRYSANTHEMUM. 



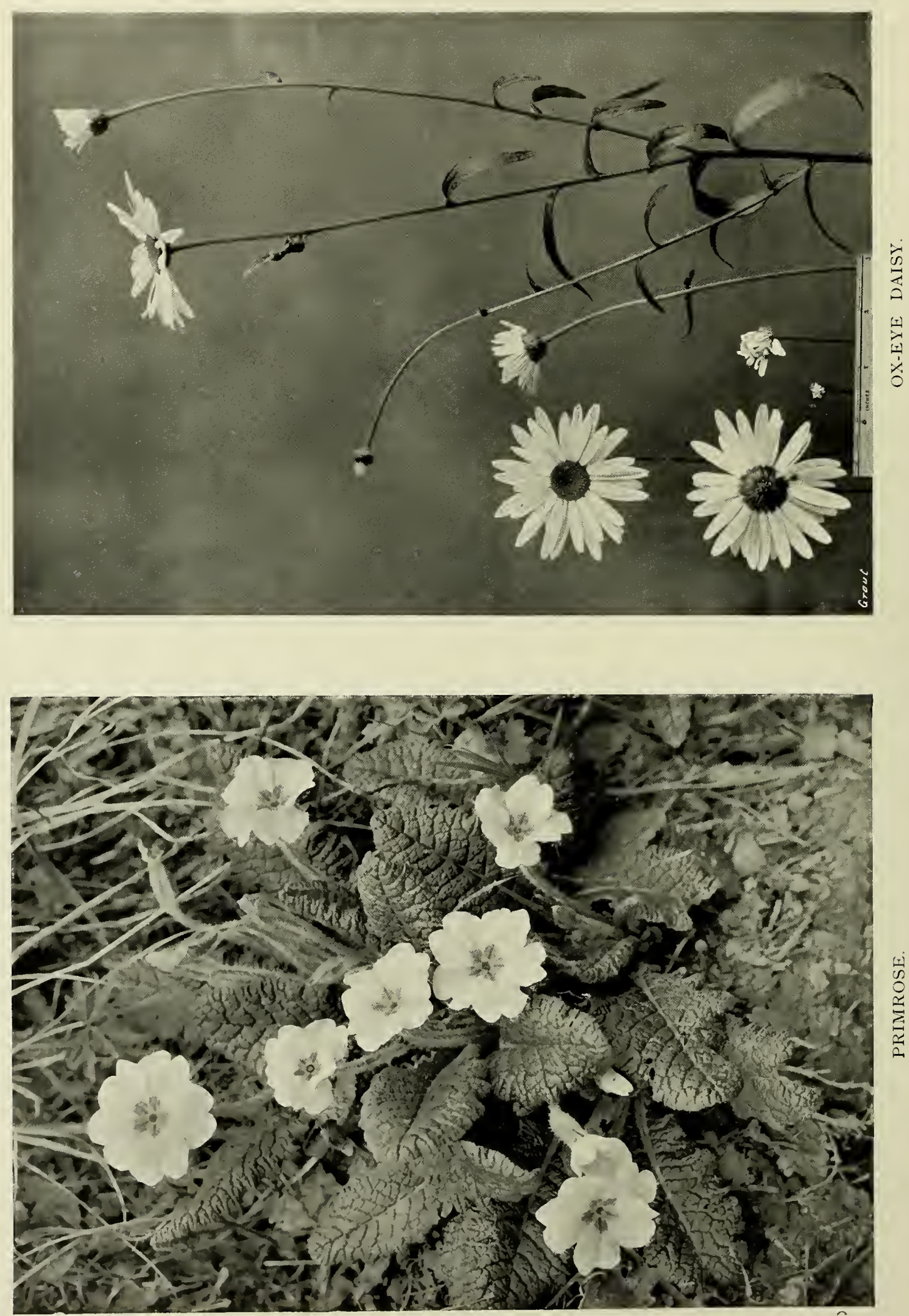


\section{OX-EYE DAISY.}

The emblematical virtues of the common Daisy and its symbolism are such as to make it impossible to apply them to its more grandiose cousin, the Ox-eye Daisy. The humility of the former flower, which caused it, for instance, to be chosen as the device of Margaret of Anjou, with the motto Humble et loiale is far from apparent in the bold upstanding blossom now illustrated; though the decoration of the "Salt-cellar enamelled with the arms of the King (Henry VI.) and the flowers called Marguerites," was probably -as are most of the representations of the Daisy in the arts-much more like the ox-eye than Burns's "wee modest, crimson-tipped flow'r." The ox-eye itself was used a good deal in brocades and needle-work and is very effective. A graceful form, which may be recommended to designers, can be obtained from a vertical cross-section of this blossom.

\section{PRIMROSE.}

The old name of the Primrose was Paralisos, that of the son of Priapus and Flora, who died of grief for the loss of his betrothed Melicerta, but was, by his parents, metamorphosed into the flower. It was the emblem of girlhood, and has thus been ennobled by the attention of painters from Botticelli to Birket Foster, and of poets who can hardly be numbered. The references to this, the sweetest of spring flowers, by Spenser, Shakespeare, Milton and Wordsworth are too well known to bear quotation; but one is tempted to parallel the famous lines of the latter, with those of the old Elizabethan poet William Browne, of Tavistock (I590-I645).

"As some wayfaring man passing a wood

Goes jogging on, and in his mind nought hath, But how the Primrose finely strew the path." 


\section{LILY OF THE VALLEY.}

This flower is not a true lily, but the tradition of ages has so closely associated the name with it that its right thereto can hardly be challenged. In Gerard's time this was recognised, and he calls it "Conval Lilly (from Convallis, a valley), May Lillies, Lillie of the Vallie and Liriconfancie"-the last a delightful if somewhat cryptic appellation, the loss of which must be regretted. In the language of flowers, the Lily of the Valley means Return of Happiness. On the continent, where it is indigenous from Italy to Lapland, it is generally called May flower, or May Lily (Meyen Blumlen, Muguet de Mai, Mughetto). So lately as 1597 it grew wild on Hampstead Heath, and "Bushie heath" (Gerard). It used to be considered a valuable medicine for disorders of the head and nerves. 


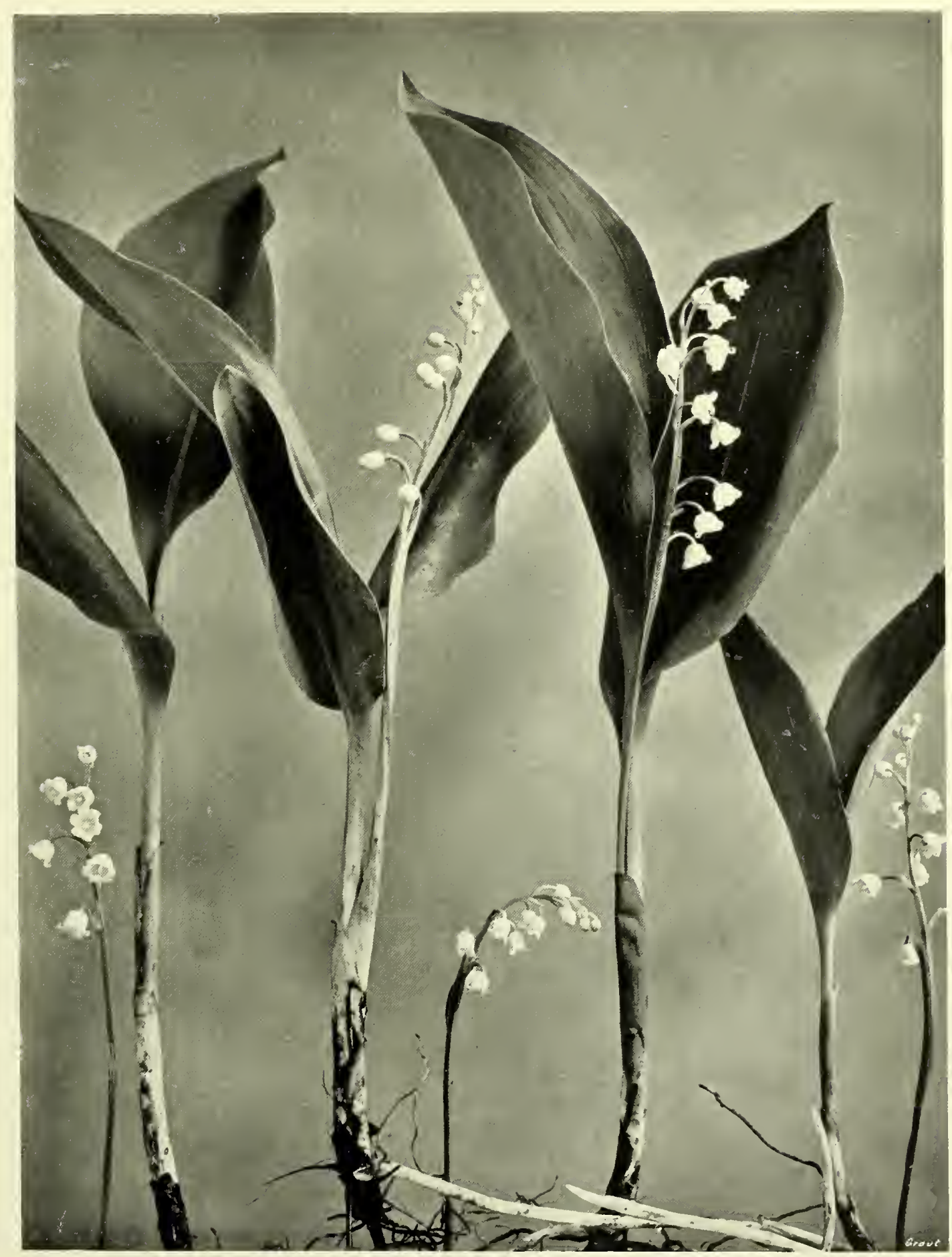

LILY OF THE VALLEY. 



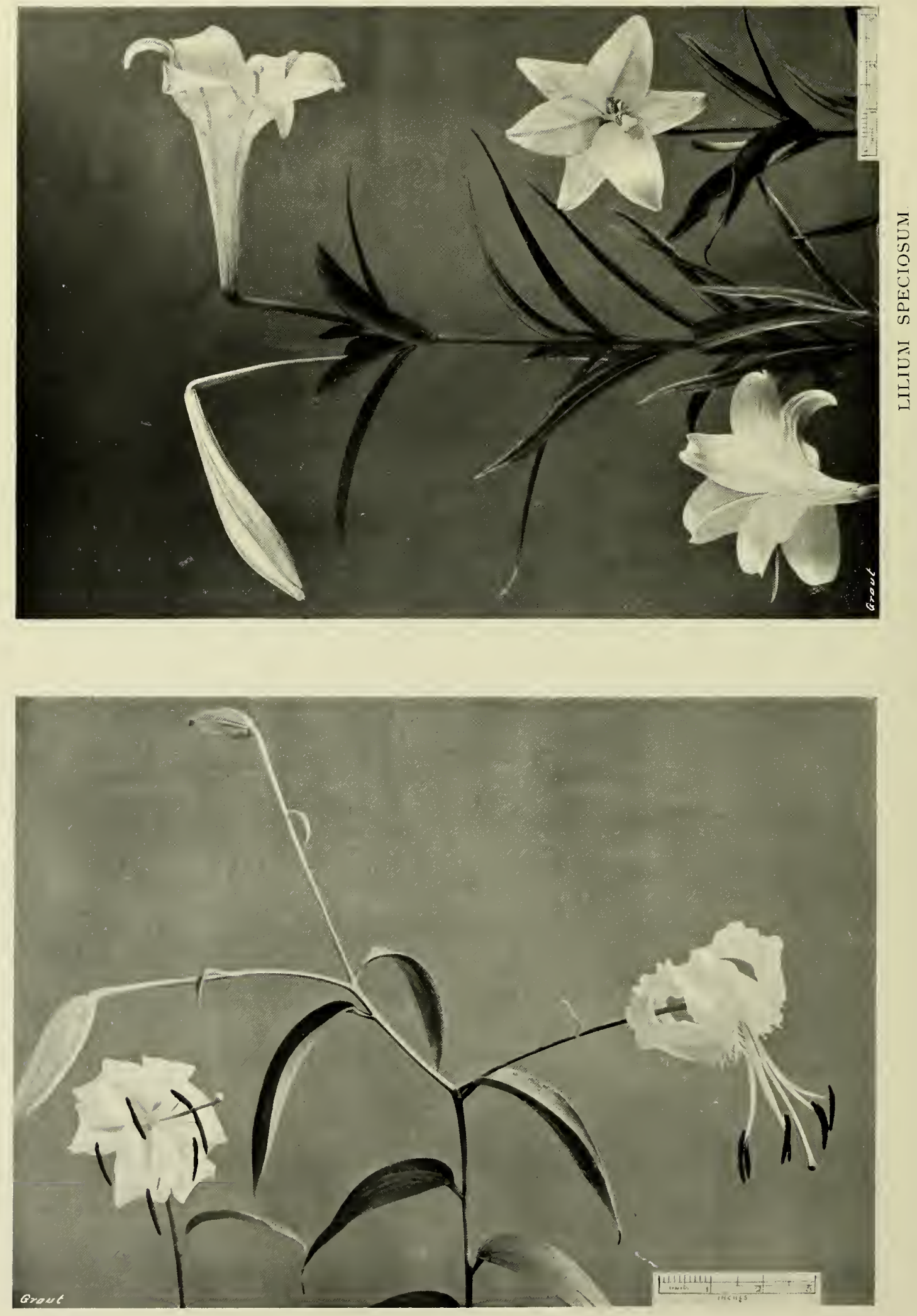

LANCIFOLIUM LILY. 


\section{9, 50. LILIES-LILIUM SPECIOSUM AND}

\section{LANCIFOLIUM.}

The true Lilies do not appear to have been grown in this country until after the end of the sixteenth century. White, orange and martagon lilies were introduced from the Levant,

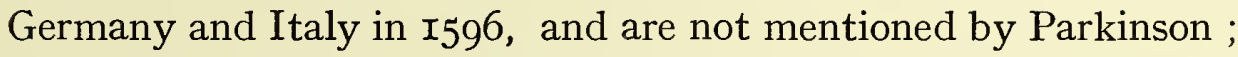
but in Dr. William Salmon's herbal these and other varieties are described. But although the plant itself was so late in coming, the flower was already known, from its heraldic and artistic associations with the Blessed Virgin, to whom it has always been devoted. The "Lily-pot," one of the devices of the Pewterers' Company, is mentioned in one of its inventories so early as I $45 \mathrm{I}$; and, next to the rose, no flower has been so much used in heraldry. The Lily-pot is also borne in the arms of New Inn. Lilium lancifolium came from Siberia in $\mathbf{1 8 2 0}$, and Lilium speciosum from Japan in I833. In some of the latter Japanese books the lily is very finely treated. 


\section{I. WHITE WATER LILY.}

The Water-lily affords another case of misleading names, for it is, of course, not a lily at all. Indeed, the old writers seem to have used the terms rose and lily in a quite loose and illogical way, without reference to scientific distinctions or any other consistent reasons. The white water-lily belongs to the order Nymphsea. It is indigenous to this country, although several of its allies are importations. It is closely related to the Lotus, to the decorative uses of which some reference has been made in the Introduction, and may supply a convenient basis on which the designer can work out modifications of the old Egyptian and Oriental themes. A curious property of the water-lily may be mentioned : its blossom opens, in favourable conditions, at about seven o'clock in the morning, and closes at four in the afternoon.

\section{CLARKIA.}

Clarkia has but a short history. It was first brought to England from North America in 1826 by Captain Clark, who accompanied Captain Lewis in his expedition to the Rocky Mountains, and other varieties from California followed in 1832 and $\mathbf{1 8 3 4}$. It is only in comparatively recent times that the flower has been at all generally cultivated, and so far it has acquired neither legend nor symbolism. But its charming foliage and effective and suggestive blossom may well serve to gain for it a lasting and honoured place in the herbal of the artist. 


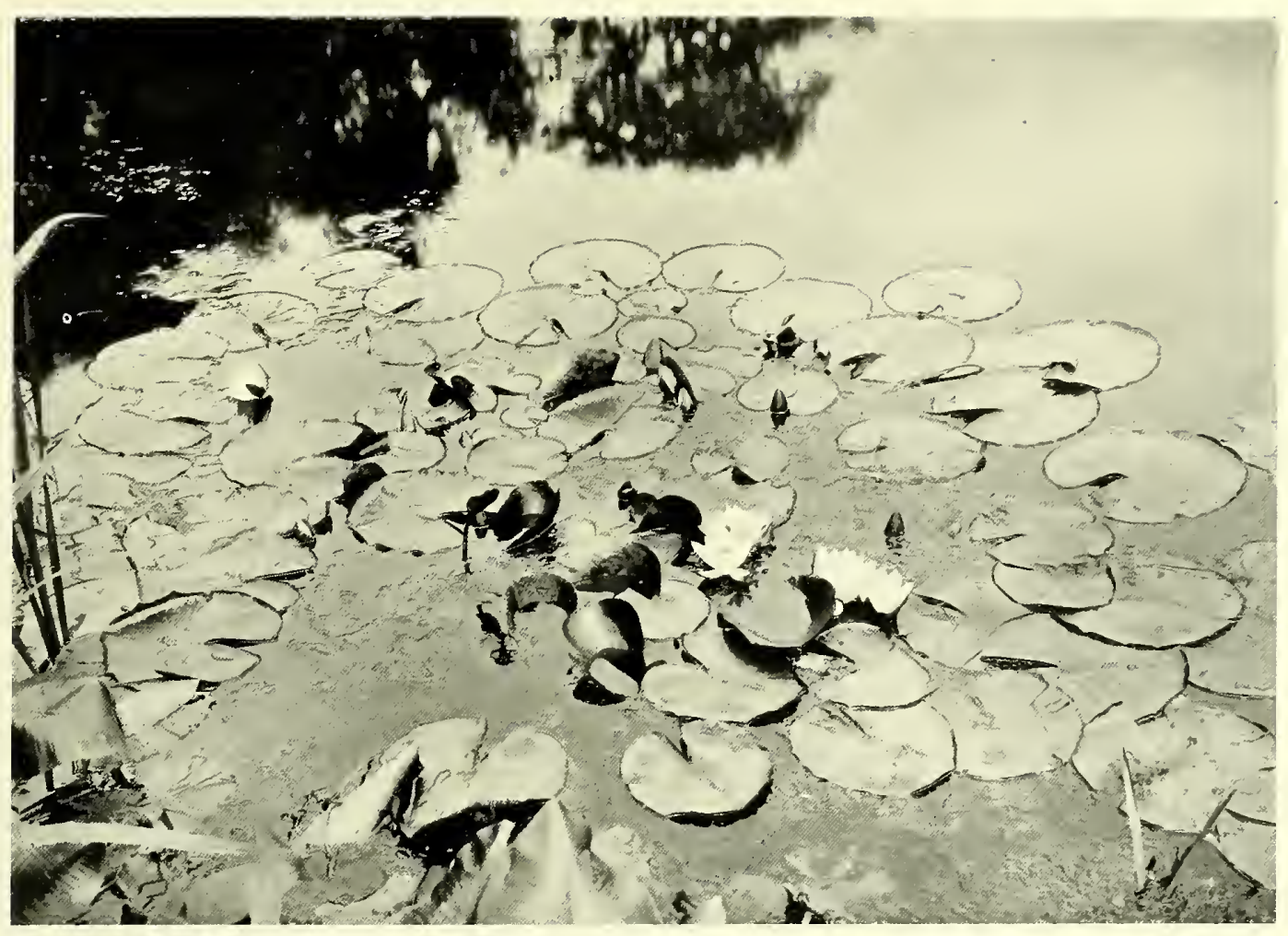

IVHITE WATER LILY

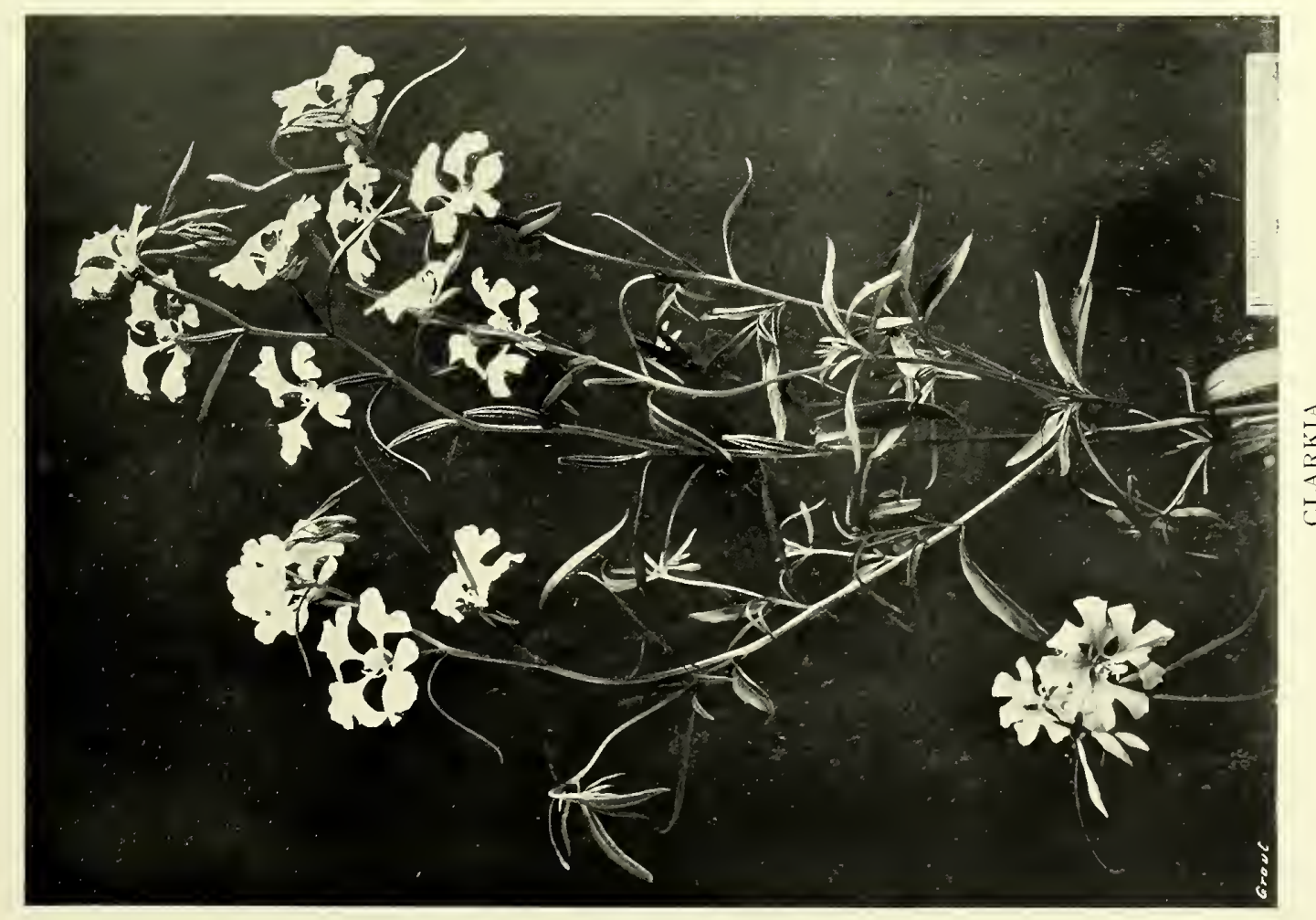






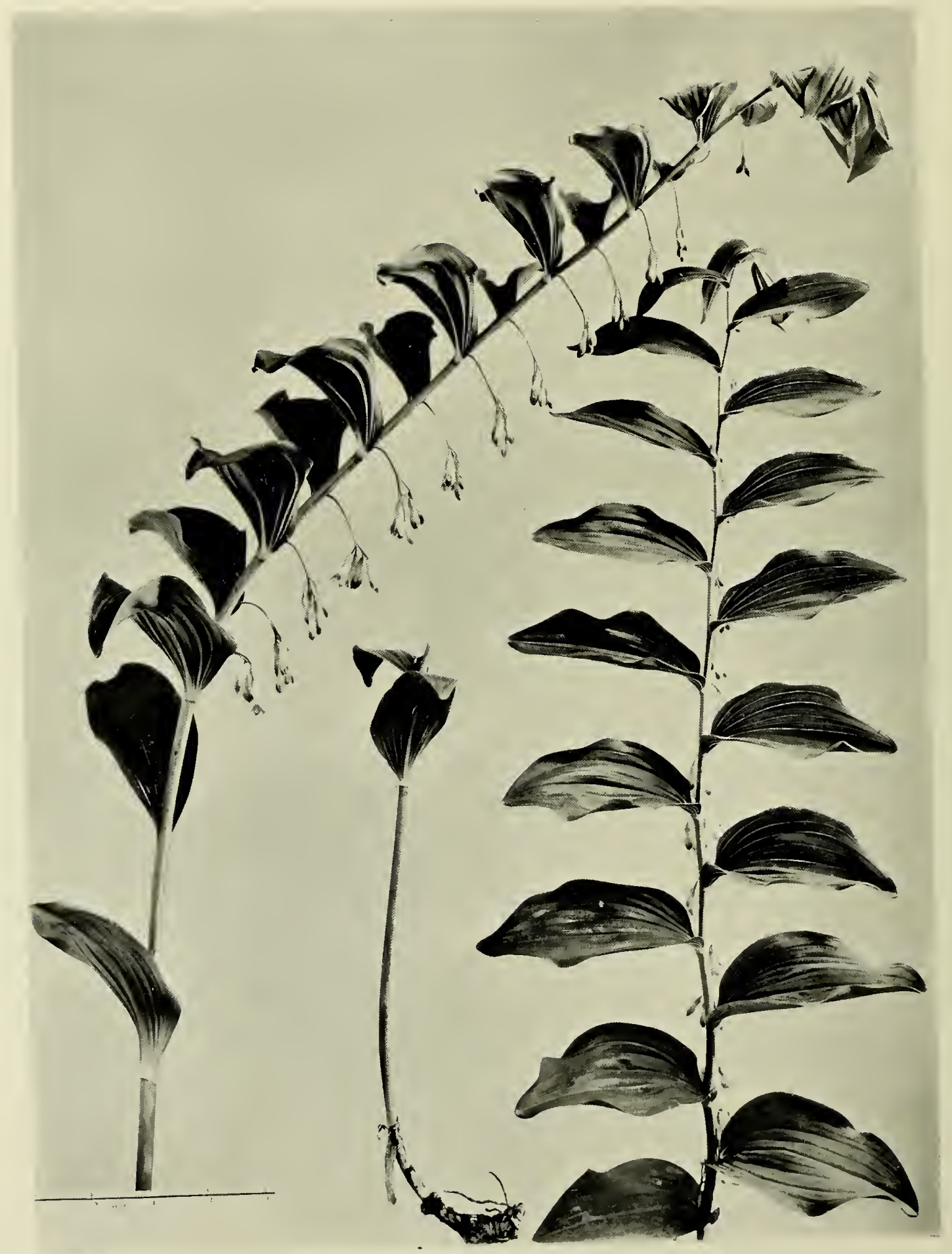

SOLOMON'S SEAL. 
53. SOLOMON'S SEAL.

This is really a variety of Convallaria, and closely akin to the Lily of the Valley. Its curious name, which is the same both in France and Italy, is said to be derived from the fact that on cutting the root transversely characters bearing some resemblance to a seal may be seen. Gerard, however, thought that the origin of the term lay in the efficacy of the root as a healer, or sealer-up of wounds, for which purpose it was prescribed by Dioscorides. In one of the medical books of Queen Elizabeth's day we are solemnly instructed that " the roots of Solomon's Seale, stamped while it is fresh and greene, and applied, taketh away in one night or two at the most, any bruse, blacke or blew spots gotten by fals, or woman's wilfulness, in stumbling on their hastie husband's fists, or such like!" In times of famine the roots have been eaten for bread, and a Turkish dish consists of the lower stalks prepared like asparagus. The splendid decorative qualities of this plant have been strangely neglected by designers. 


\section{YELLOW IRIS.}

"The Flower de luce," says Parkinson, "is called Iris from the Rainbow, whose various colours the flower thereof doth imitate." The writer of the earlier Southwark Herbal (I526) identifies the Yellow Iris with the Gladiolus or "Iris Affryke," and says that the seeds of the white variety, with milk of an ass or goat, drunk warm, are good for " payne of the herte." But the chief interest of the family to which this flower belongs attaches to its heraldic associations, for herein we have the origin of the famous fleur-de-lys. This device is said to have been used for the royal badge of France in the time of Eudes (A.D. 888); but its first authentic appearance on the French banner was during the reign of Louis VII. (II37-II80). The number of fleurde-lys on the arms of France was reduced to three by Charles VI. about the year 138I. It formed part of those of England from the reign of Edward III. until I January, I8oI. This flower, also, was called a lily, as Shakespeare wrote :-

"Lilies of all kinds,

The Flower de Luce being one."

It occurs on the head-dress of Egyptian Sphinxes, and has been otherwise used in the arts on numberless occasions. 


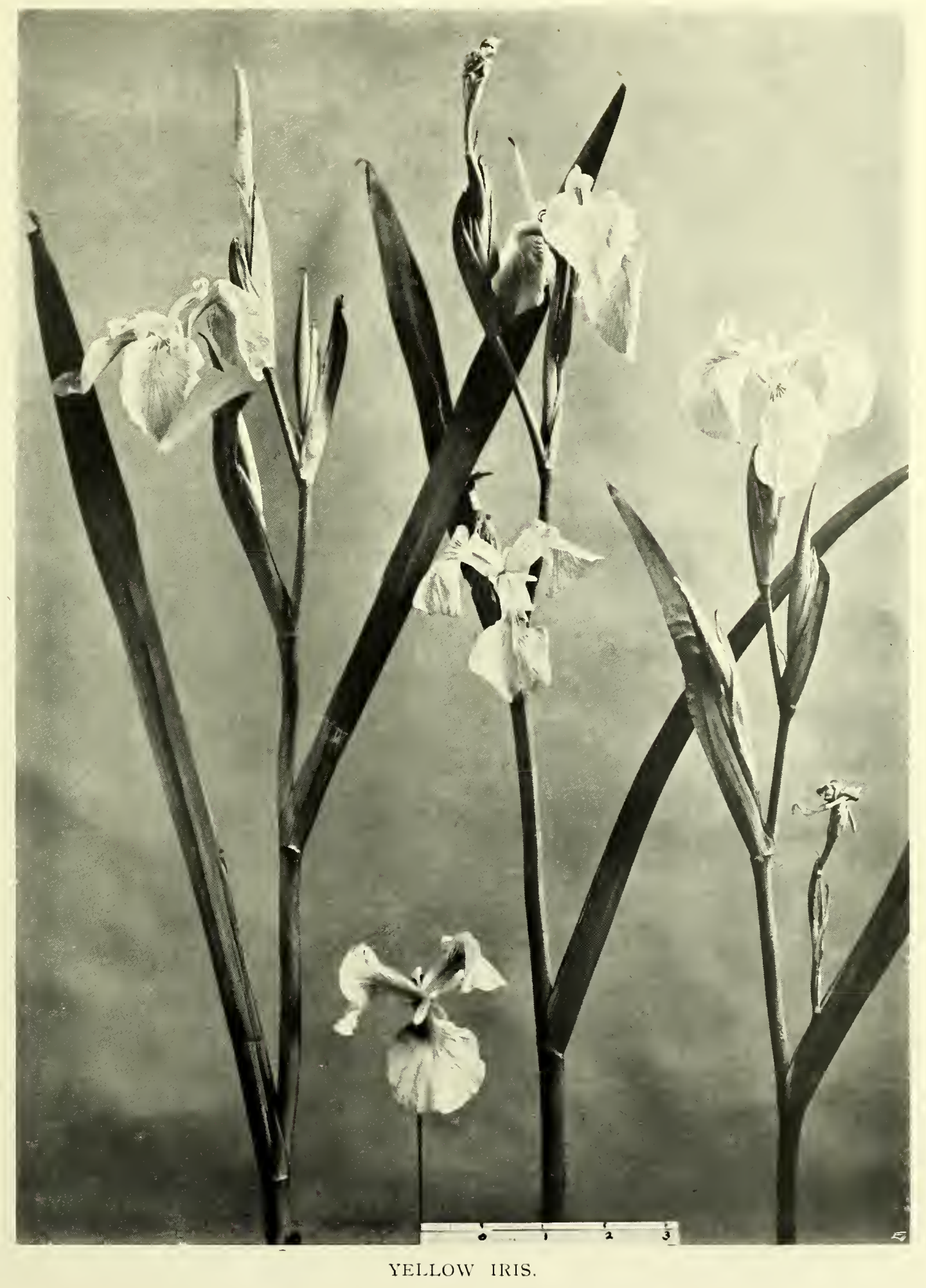





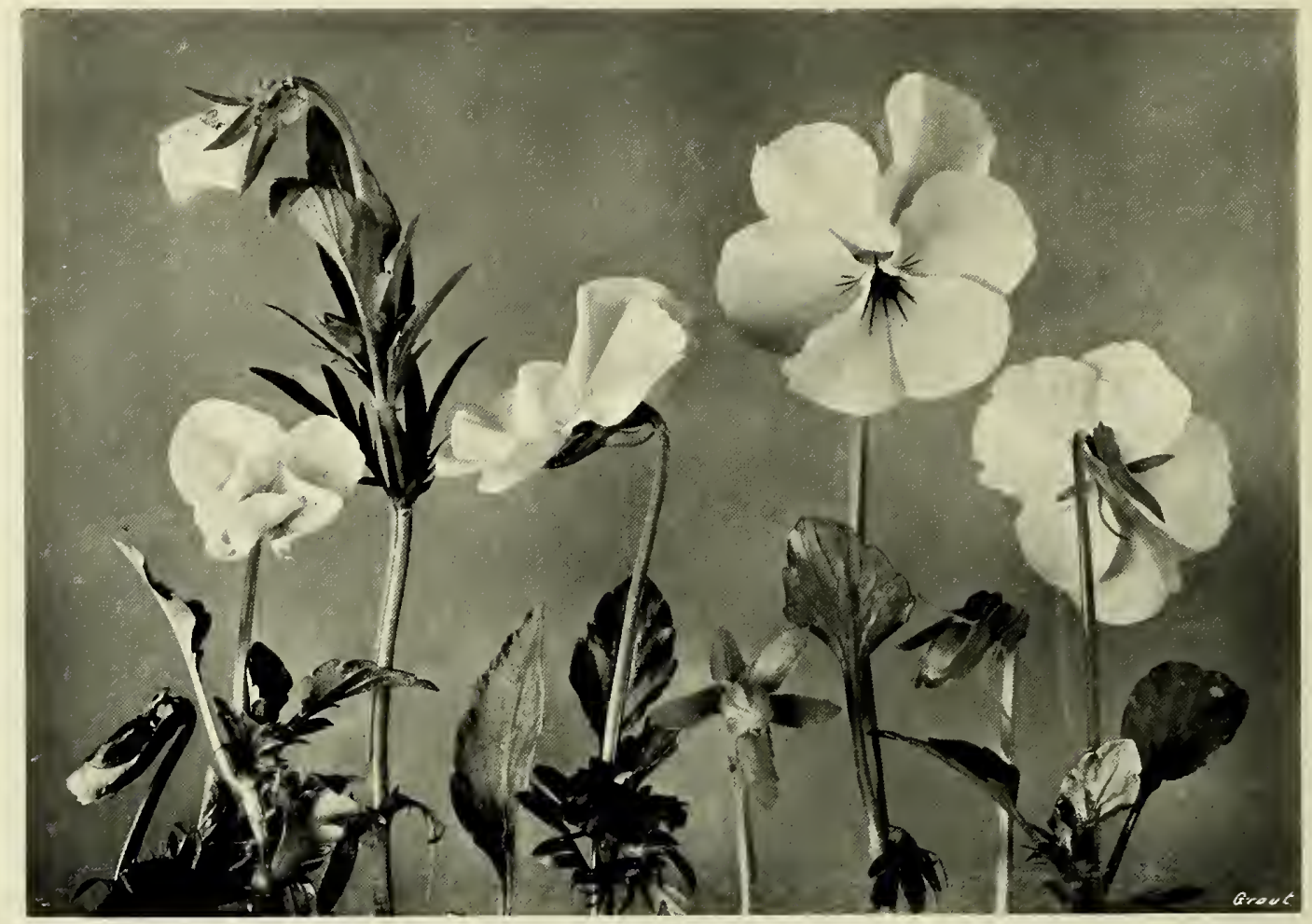

PANSY

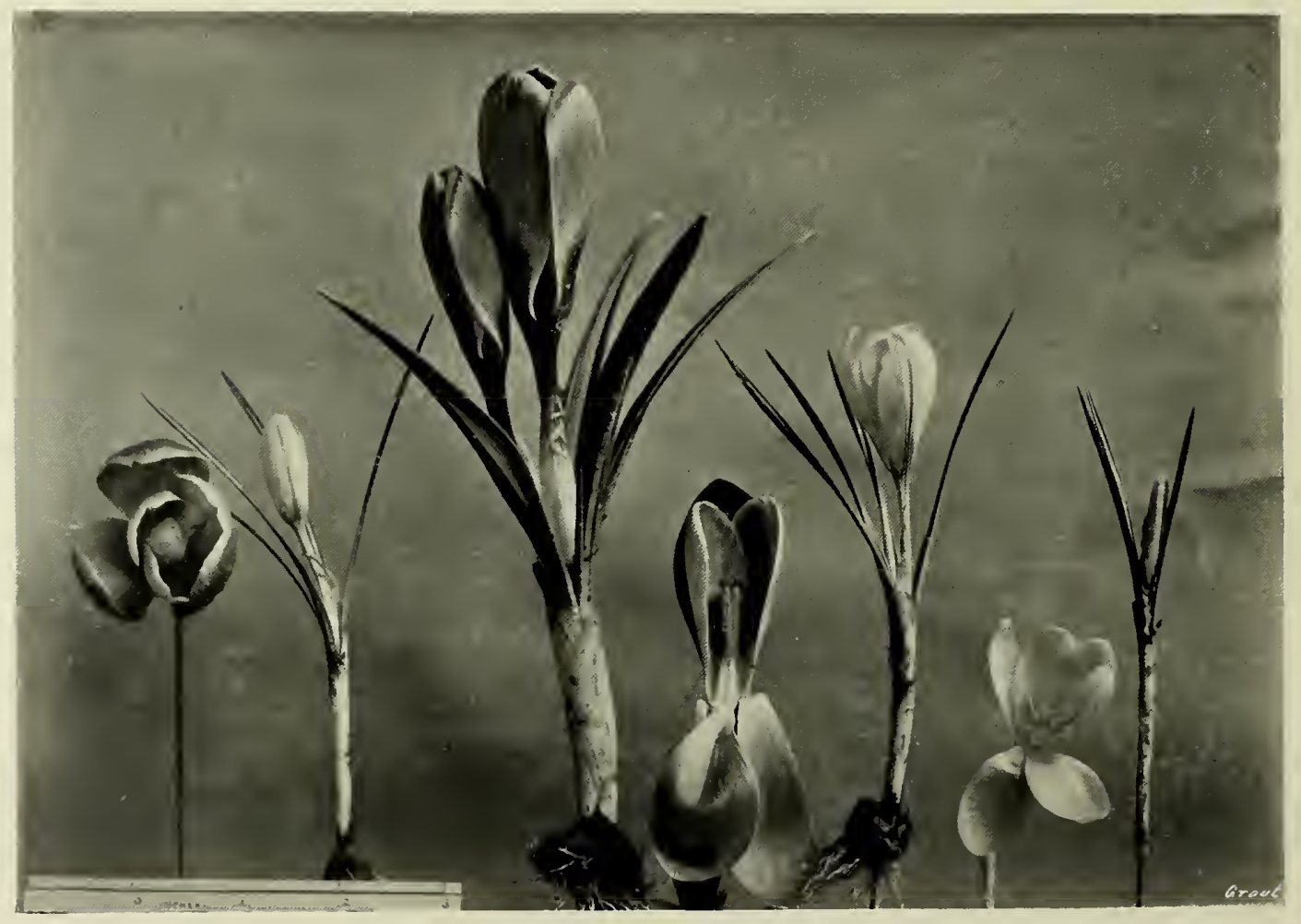

CROCUS. 


\section{PANSY.}

The Pansy has a wealth of old-world names-Heart's-Ease, Love-in-Idleness, Herb Trinity, Three Faces under a Hood, Flame Flower, Jump up and kiss me, Flower of Love, Pink of my John are a few only. Its symbolism has been once for all stated by Shakespeare.

And there is pansies, that's for thoughts.

In the traditional Oxfordshire Children's May Song we have "Spring is coming, Spring is coming,

Flowers are coming too:

Pansies, lilies, daffodillies

Now are coming through."

The Pansy was used in the borders of Illuminated Manuscripts, and the recent revival of the old art of enamels has shown it to be particularly well adapted to the decorative uses of that fine handicraft.

\section{CROCUS.}

This flower is said to have been named from a beautiful youth, Crocus, who was consumed by the ardour of his love for the nymph Smilax, and afterwards metamorphosed into a plant. Another derivation is from Coriscus in Cilicia. It appears to have first been introduced into English gardens during the reign of Queen Elizabeth; and Gerard says that it was sent to him "by Robinus of Paris."

The Crocus has, of late years, been a great favourite with designers of flat patterns, wall-papers, textile fabrics, and tiles, and its fine curves and colouring lend themselves especially to these purposes. The saffron variety appears on the arms of Saffron Waldron, where it was once largely cultivated, by a grant of Edward VI. ; and it was the device of Pietro Loredano, with the motto Conculatum uberius-more fruitful when trodden on. 


\section{THE SNOWDROP.}

The Snowdrop seems, most appropriately, to have been formerly held sacred to virgins; and especially to have been cultivated in monastic gardens, in later pre-Reformation times, when it was probably introduced into this country from Italy. Gerard notes, "These plants do grow wilde in Italie and the places adjacent, notwithstanding our London gardens have taken possession of them all, many yeares past." In the early part of the seventeenth century it was still rare in Holland. Tickell refers to it

"A flow'r that first in this sweet garden smiled,

To virgins sacred, and the snowdrop styled."

It has not been put to much practical use by designers, although Mr. Walter Crane has many times availed himself of its charming simplicity of outline and colour.

\section{TULIP.}

The Tulip is of Oriental origin, and was first brought into this country about the year I577 from Vienna, where it had been obtained from the Turks. It has formed, for many centuries, one of the principal forms in Persian and Turkish decoration, and is treated with fine effect, especially on the pottery of those countries. The story of the craze to which the cultivation of this flower gave rise in Holland and France, during the seventeenth century, has often been told. It is said that in three years the trade of the city of Haarlem alone, in tulips, amounted to ten million pounds sterling. For one bulb, I3,000 florins were given, and there are countless anecdotes still recorded of the excesses of Tulipomania at this time. The flower does not seem to have been known to the Romans, and, in their times, had probably not travelled farther west than Persia. In I554 it was still something of a rarity at Constantinople. Duke Carlo Gonzago (died I657) had, for his device, a tulip looking at the sun. 

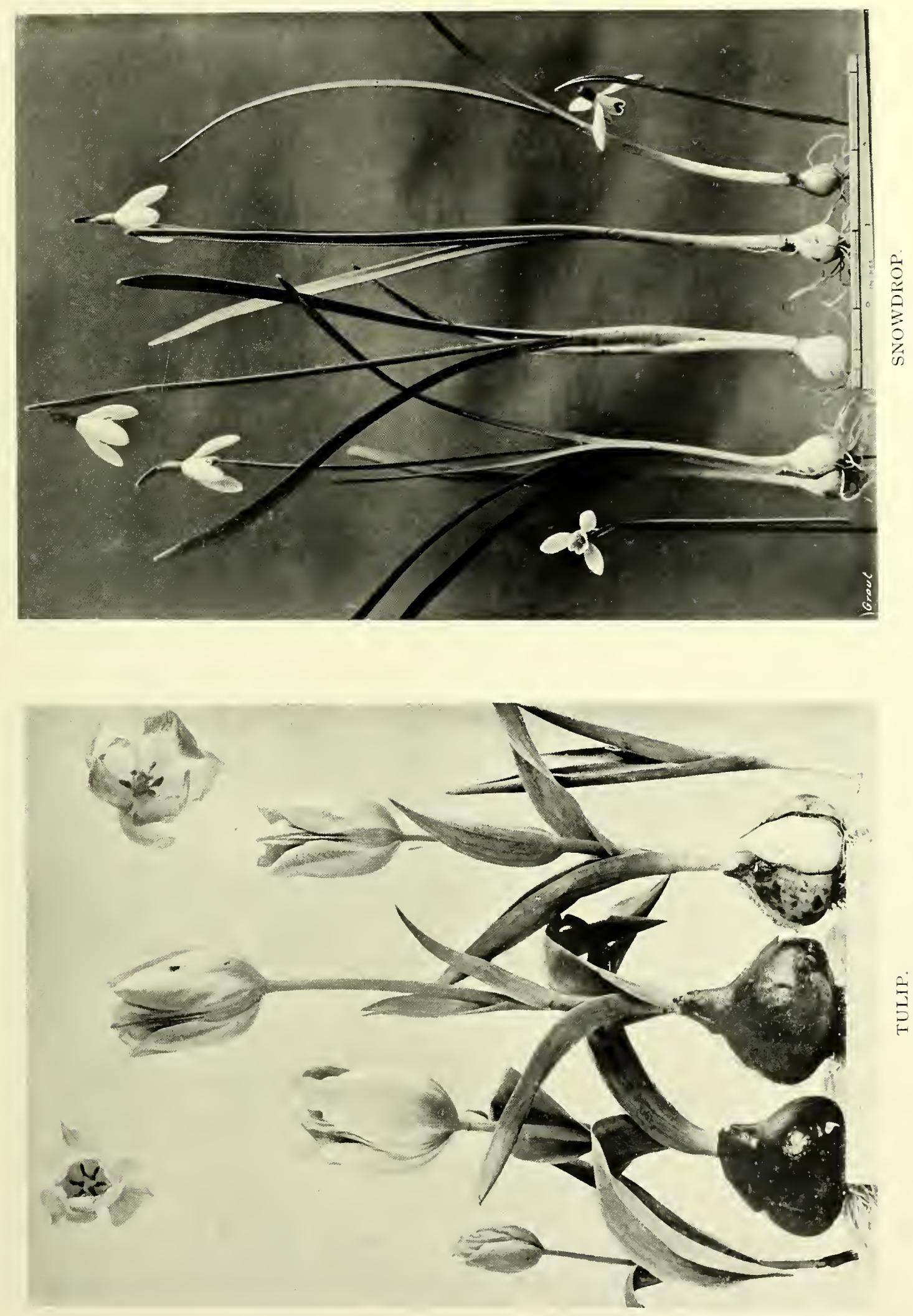



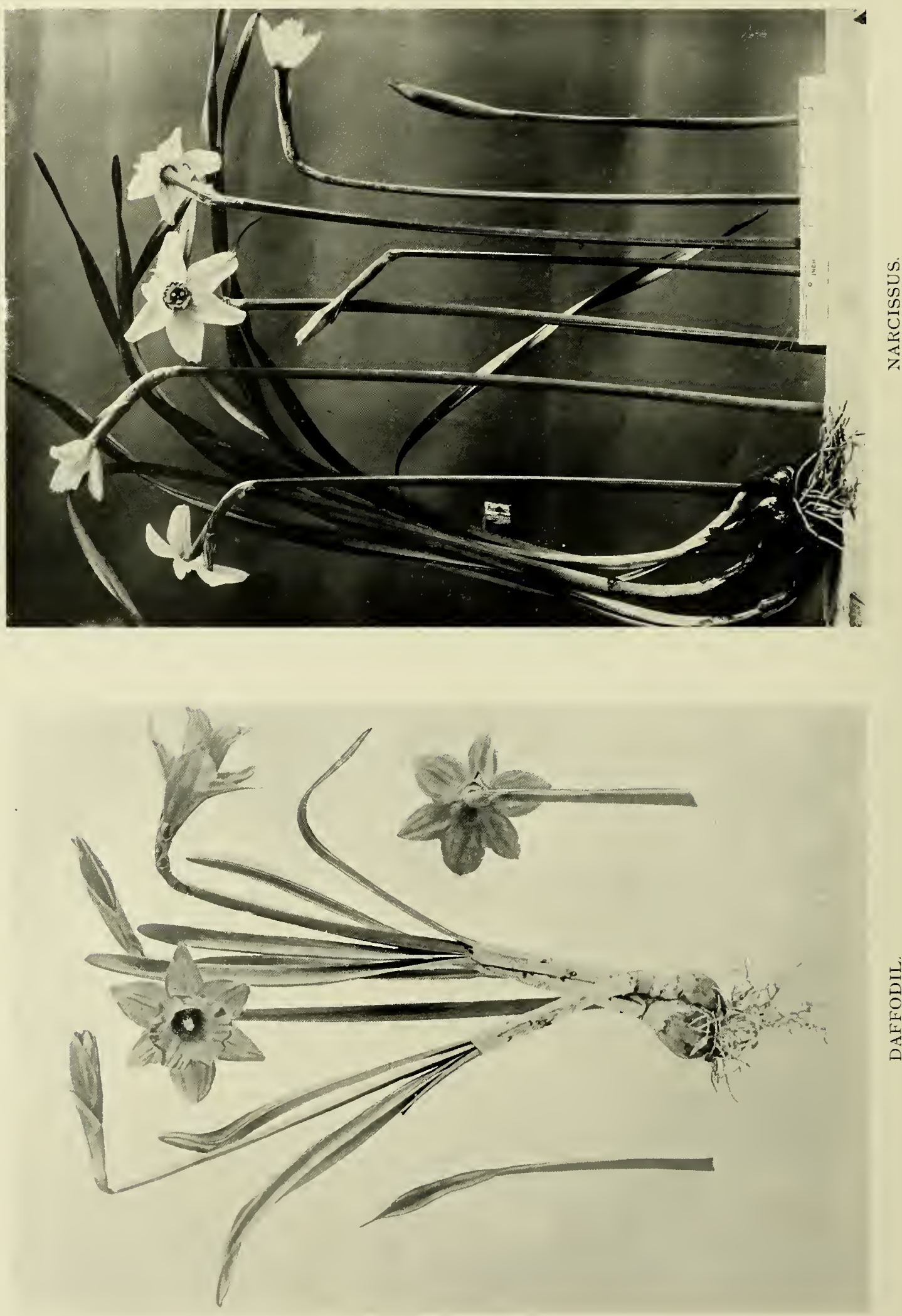

量 


\section{9, 60. NARCISSUS AND DAFFODIL.}

The Narcissus family claims two of the best-known legends of flowers. Daffodils (Daffodown-dillies or diffadillies, as Spenser on different occasions calls them) were the flowers that Proserpine was gathering when she was abducted by Pluto ; and the Narcissus itself is named after the hero of the well-known story, in Ovid's Metamorphoses, of the youth who was changed into this flower for slighting the love of the nymph Echo, being so absorbed in admiration of his own shadow. For this reason it symbolises egotism and self-love. Daffodils have also been called Chaliceflowers, and Lent-lilies. There is a native variety, and most of the others have been settled in this country since the sixteenth century. The Jonquil, another member of the family, is the emblem of desire. 


\section{I. WILD HYACINTH.}

The Wild Hyacinth (the Blue-bell of children), is one of the oldest favourites of the countryside. It is the emblem of play and games, and derives its classical name from the story of the death of Hyacinthus, who, beloved both by Apollo and by Zephyr,was killed by the latter, who blew Apollo's quoit aside so that it fell on the head of the youth. In his honour an annual festival of three days was held at Amyclæ, when games were held and slaves liberated. It formed one of the flowers in the bed of Jove.

"Saffron flow'rs and hyacinths

Helped make the sacred bed."

Homer's Iliad, Book XIV. (Chapman's Trans.)

The flowers are sometimes found both white and carnation colour. In the sixteenth century the bulbs were used to make starch for the high ruffs of Queen Elizabeth's courtiers, and also for bookbinding. Dioscorides recommends the root as a hair restorer.

\section{DIELYTRA EXIMIA.}

Dielytra Eximia, a beautiful and hardy plant, which we seem to identify with what an old gardener once told us was "Dutchman's Breeches," was introduced from North America in I8I2, other varieties having arrived as early as I73I, and one,

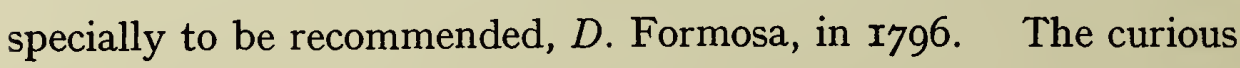
formed and delicately tinted blossom, and the deeply serrated leaf should give valuable suggestions of ornament. 

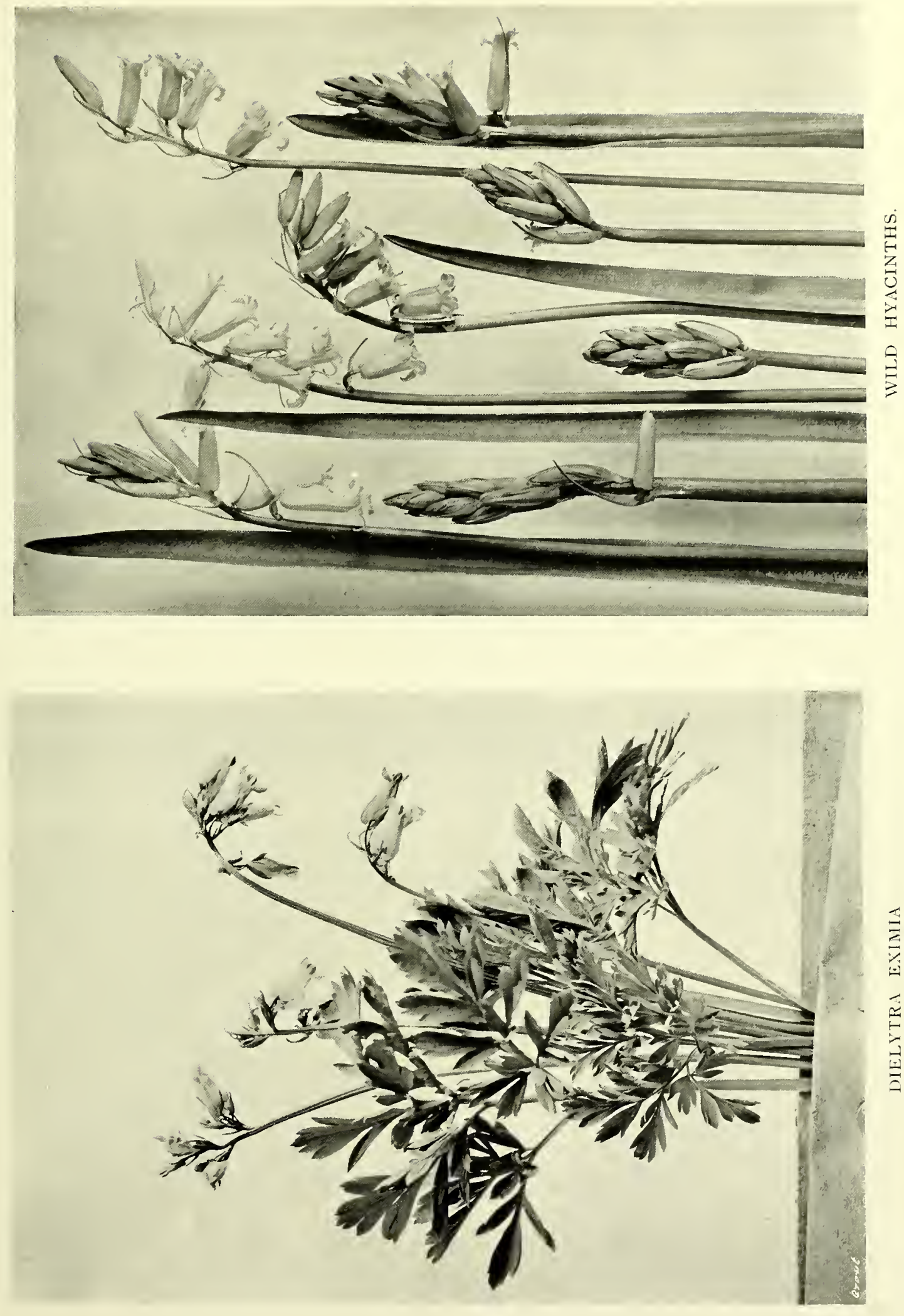



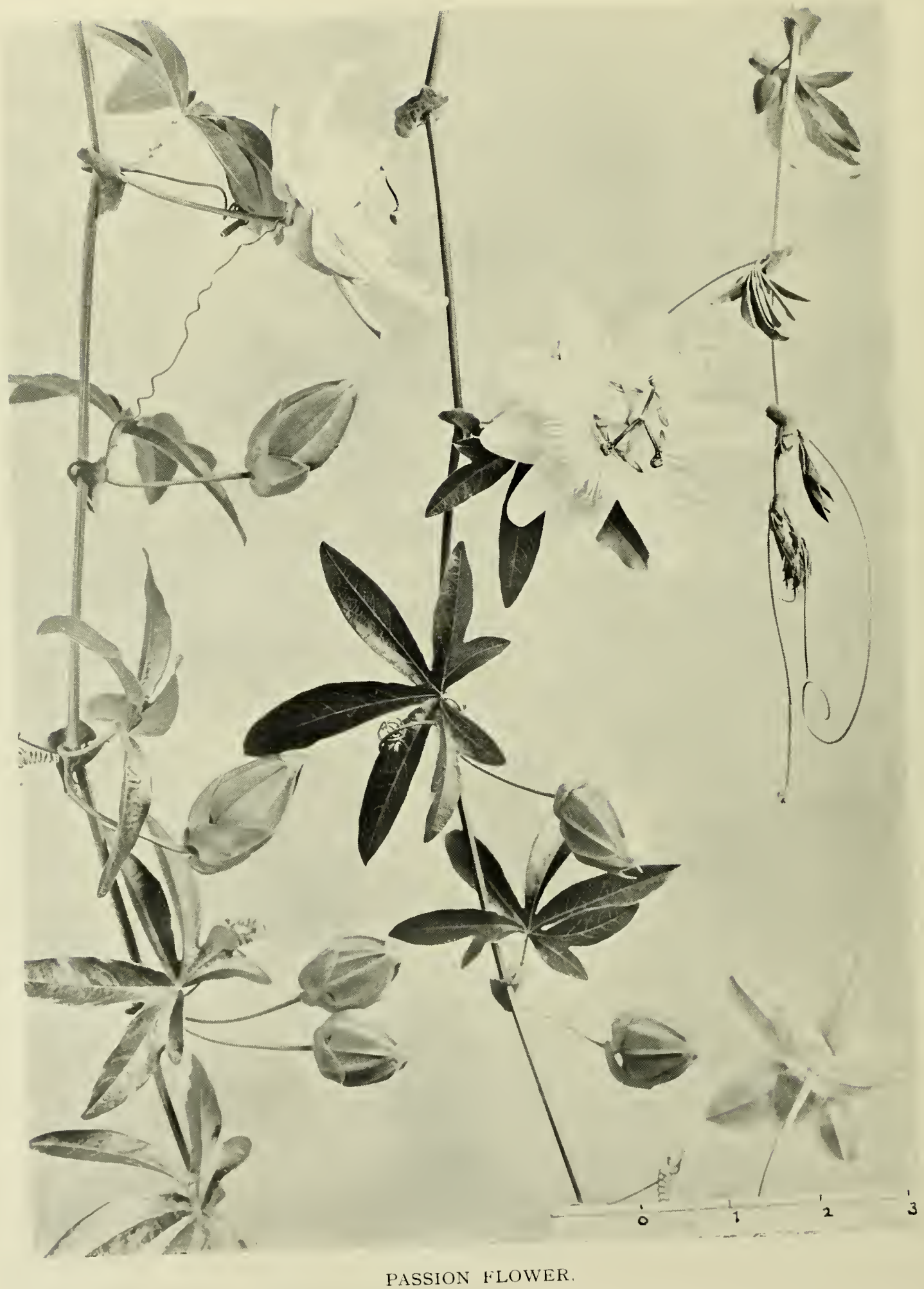




\section{PASSION FLOWER.}

The first Passion Flower came into England from the Bahamas in I724; and other varieties followed from the West Indies and from Brazil, during the remainder of the 18 th and early part of the Igth centuries. Several of these, under favourable conditions, produce a fruit which is pleasant to eat, varying in size from that of a grape to a cucumber-shaped vegetable, as much as 6 inches in diameter and $I_{5}$ inches in length. It derives its name from the curious and intricate formation of the blossom; but the handsome foliage will probably be found, by designers, to be of more practical value, though the flower has been used to good purpose in needlework. 


\section{CHRISTMAS ROSE.}

The Christmas Rose, or Black Hellebore, belongs to a wellknown family of plants, with one of the oldest of reputations. It was considered, from time almost immemorial, as a specific against melancholy and madness; and once had the name of Melampodium, from the physician Melampus of Pylos in Peloponnesus, who was said to have cured the daughters of Proteus, King of Argos, of madness, by the use of this drug. It was also used in classical times for the purification of dwellings, and as a charm against evil spirits. The whole family of the Hellebores are more or less poisonous.

\section{WHITE BRYONY.}

The White Bryony, Wild Vine, White Vine or Tetter Berries, as it is variously called, "groweth commonly abroad, ramping upon the hedges." It must by no means be confused with the Black Bryony, to which it is in no way related; but is a member of the Gourd family and a sort of poor relation of the Pumpkin, Melon and Cucumber. Its roots attain to a great size, and during the period of the mandrake superstition, this property was put to fraudulent use. Moulds, shaped roughly in the form of a human body, were placed around the young roots of a growing plant, which in course of time filled them completely, taking on the form of the mould. The product was then sold to believers as a genuine mandrake. The growth, foliage and fruit of the White Bryony are all very beautiful. 

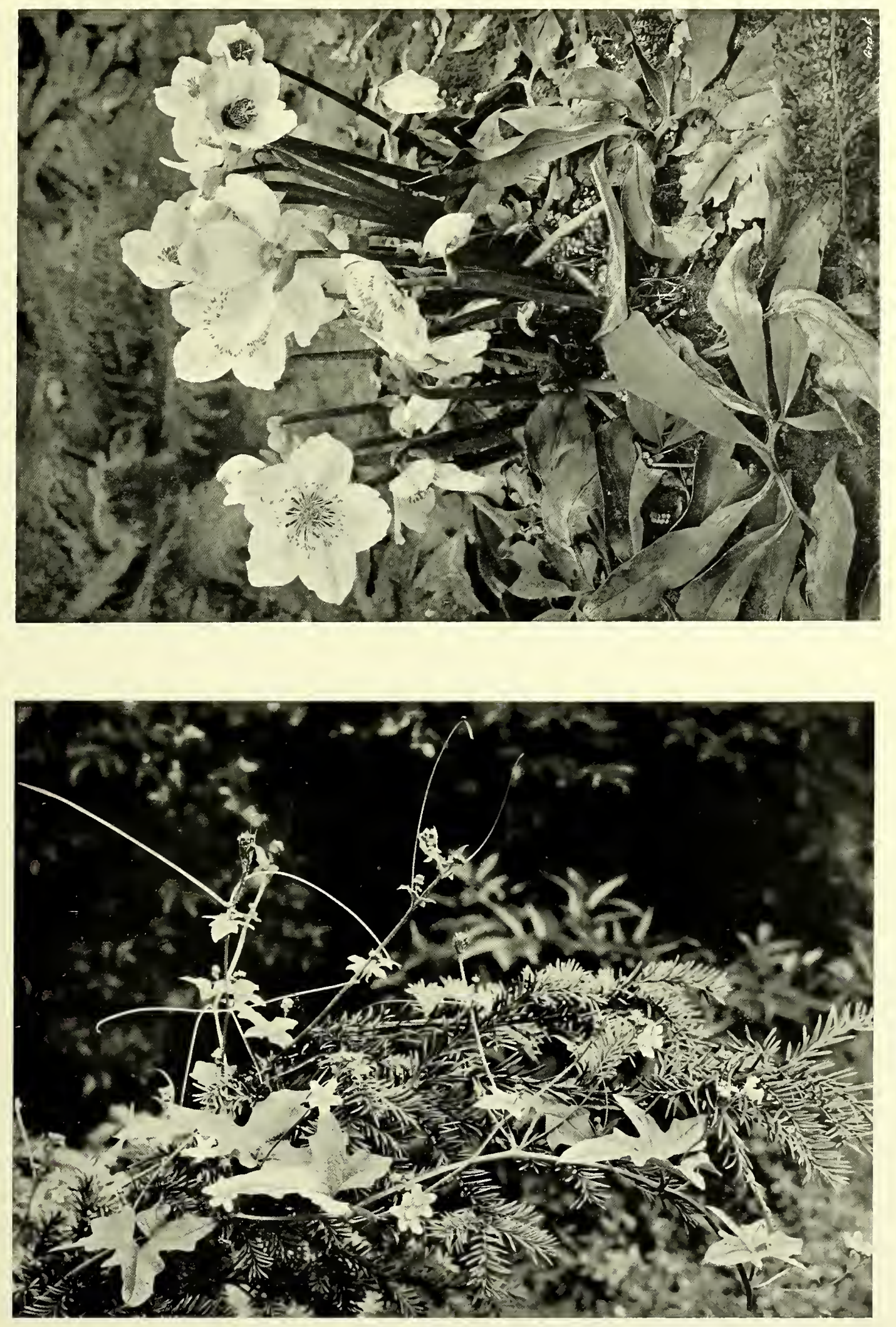

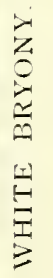






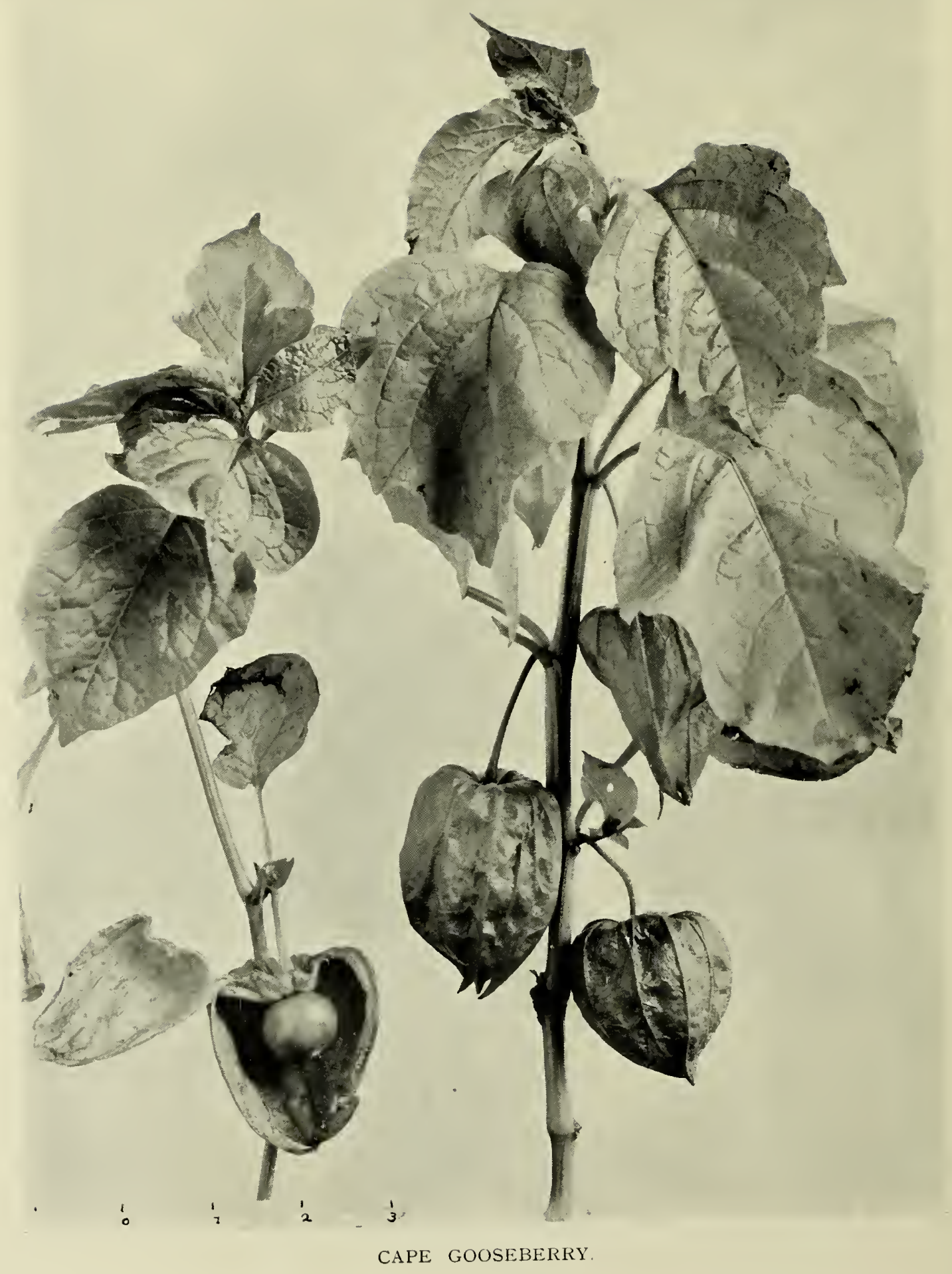




\section{CAPE GOOSEBERRY.}

The Cape Gooseberry, or Winter Cherry, has long been cultivated in this country ; first, for its reputed medicinal qualities, and later for the beauty of its fruit. The Kew Catalogue gives to it as early a date as 1548 , and it is mentioned by Dr. Turner (1546) as common in his time, under the Arabian name of Alkallinge. Parkinson calls it the Upright Indian Winter Cherry, and says it came from the West Indies, by way of Italy and Spain; while another authority dates its introduction in I596, from Madeira. The berry which is encased in the characteristic and handsome bladder-shaped calyx is largely eaten in Germany and other countries; but its great value, nowadays, is as decoration, the bladders taking on, when ripe, a superb orange-vermilion colour, which when properly dried, will endure for a twelvemonth. The larger variety was an importation from Japan. 


\section{VEGETABLE MARROW.}

The Vegetable Marrow is one of the few edible members of the Gourd family, which is easily cultivable in Great Britain. Most of them are tropical, but it is interesting to remember that among those of no practical value is the indigenous White Bryony, already referred to. To artists the Marrow should be a great delight. Its massive and well-shaped foliage, the intricacy of its tendrils, and the beauty of the perfect flower are full of suggestion for purposes of design ; while the fruit itself often acquires a graceful form and proportion, which should be of much use in pattern. 


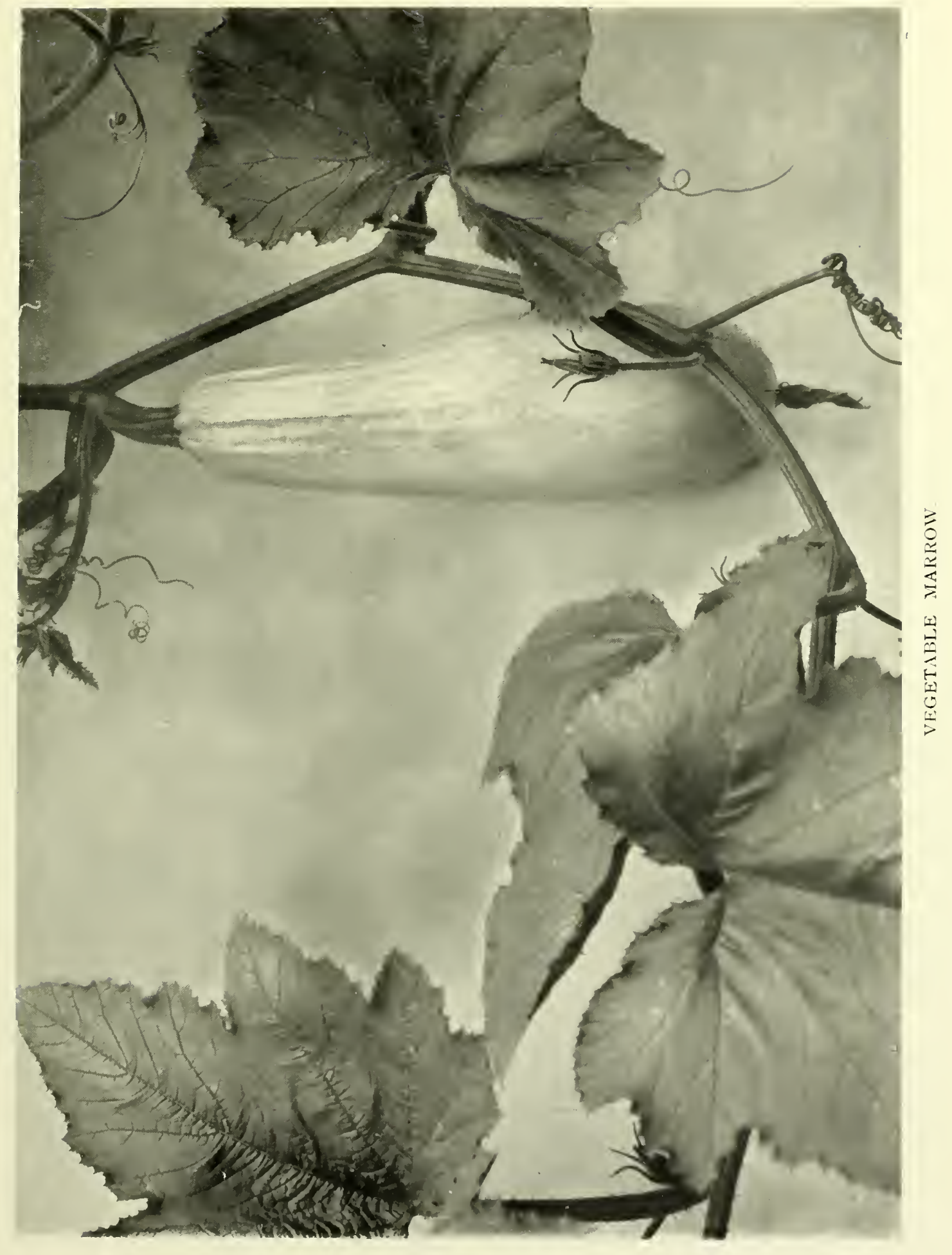






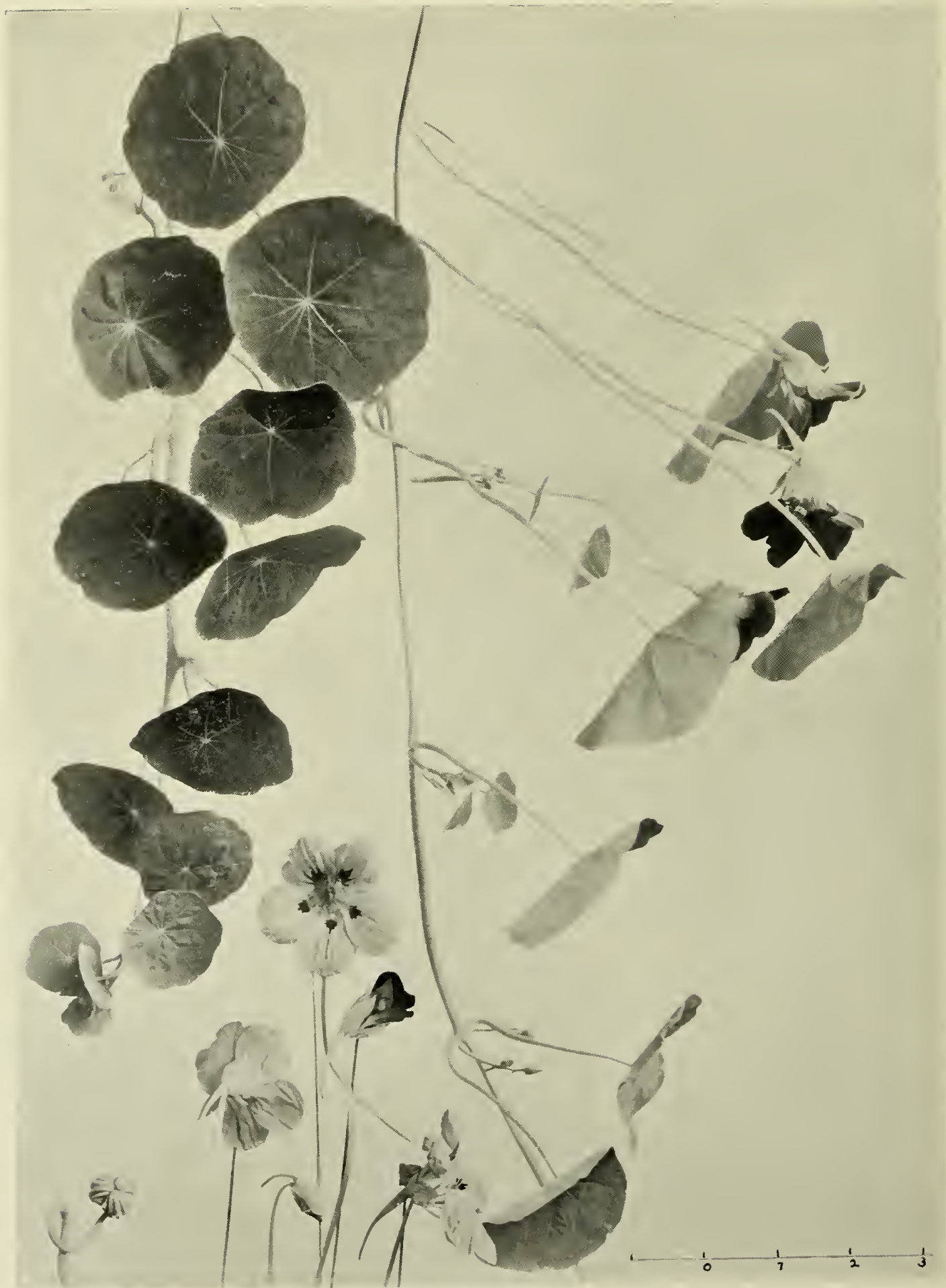

NASTURTIUM. 


\section{NASTURTIUM.}

The Garden Nasturtium (which must not be confounded, in classification, with the true Nasturtium or Water-cress) belongs to the geranium family; and may be compared usefully with the garden geranium and the wood-sorrel, of the same Order. Another name for it is Indian Cress. The Nasturtium is best studied in its larger varieties, which display to the greatest advantage the finely massed foliage, and happy combination of flower and leaf. The unopened buds are specially recommended to attention, and also the seeds when they have attained their full dimensions. These latter make, as is well known, a satisfactory substitute for capers. The Nasturtium seems to be referred to and figured as "Gardyne Cress" in the Southwark Herbal of 1526 . 


\section{EDIBLE PEA.}

The pea has a curious and unexpected share in old mythology. The primitive Aryan dragons that poisoned the air and the waters, carried evil-smelling peas and let them fall in such quantities as to fill the wells. These peas, also, are the lightning; and thus there is a connection with Thor himself, to whom peas were sacred. It was noted by a writer in this subject, that, in 1863 , peas and sauerkraut were a standing dish in Berlin on Thursdays (Thor's day)." Peas also were, in Germany, mixed with the seed-corn to bring good luck to the harvest. They were especially associated with the deities that preside over marriages; and are used for purposes of divination in various ways. In Bohemia, the girls would make garlands of five or seven differently coloured pea-flowers. When they went to bed the garland was used as a pillow, the right ear resting on it; and the believer heard a voice from underneath telling what sort of a husband she would have. In England the girl who finds a pod with nine peas hangs it over the door; and has for a sweetheart the first man who enters. "Winter time for shoe-ing, peascod time for wooing" is an old Devon proverb, and Touchstone, in "As you like it," gives an example of the method. An old agricultural maxim says,

"Sow peas and beans on David and Chad

Be the weather good or bad."

\section{IVY-LEAVED TOAD-FLAX.}

Of the Toad-flax, or flax weed, Gerard says, quaintly enough, that it is called "Herba studiosum because it is a fit thing to make brooms of, wherewith schollers and students may sweepe their own studies and closets." Also that it was a good remedy for yellow jaundice. There are many varieties of this plant; the common toad-flax with its range of colour from the palest lemon yellow to deep orange vermilion, being by no means the least interesting. The Ivy-leaved Toad-flax, which is now figured, is an old indigenous variety, easily cultivated on any old wall, and singularly delicate and beautiful in its growth. 

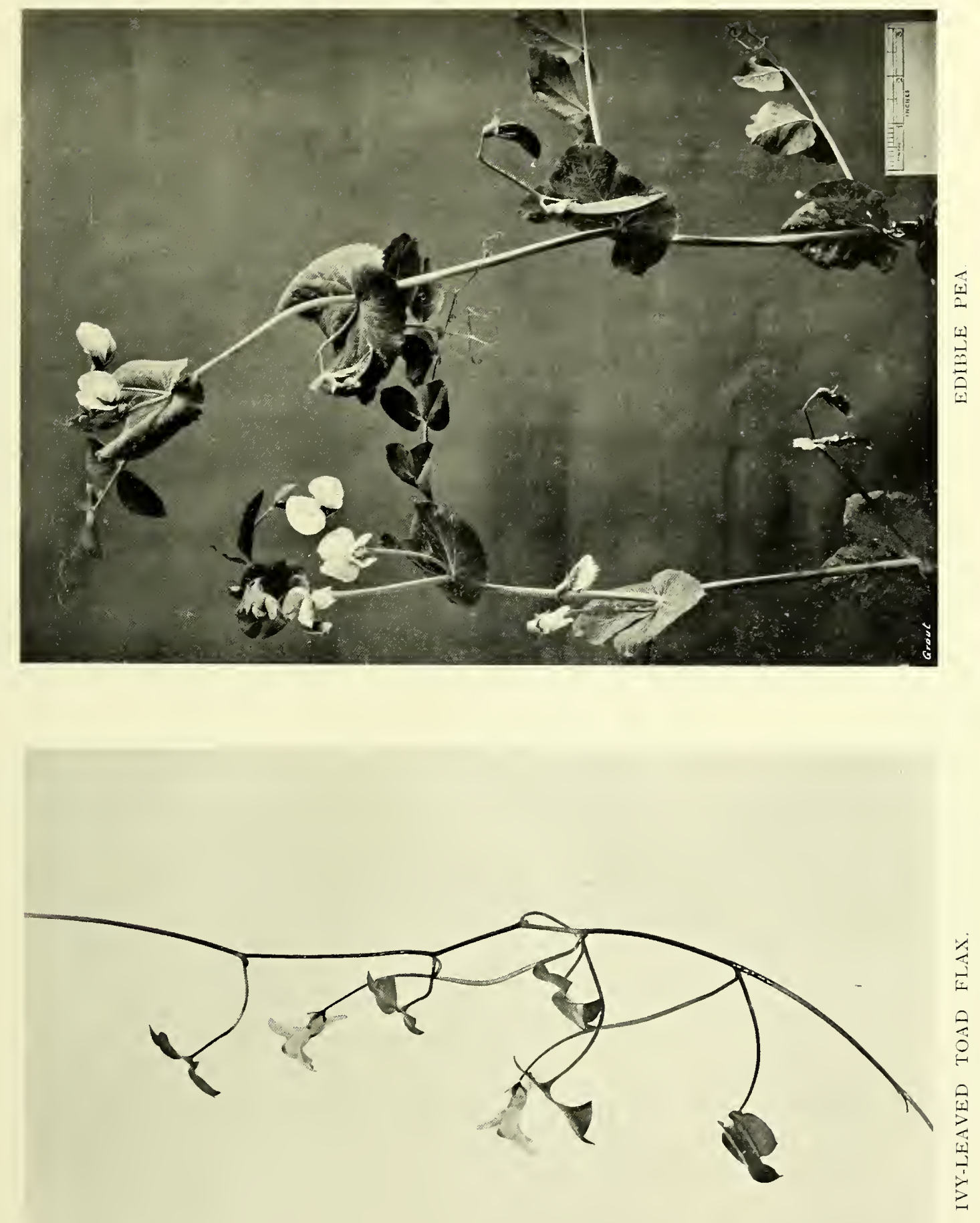

. 


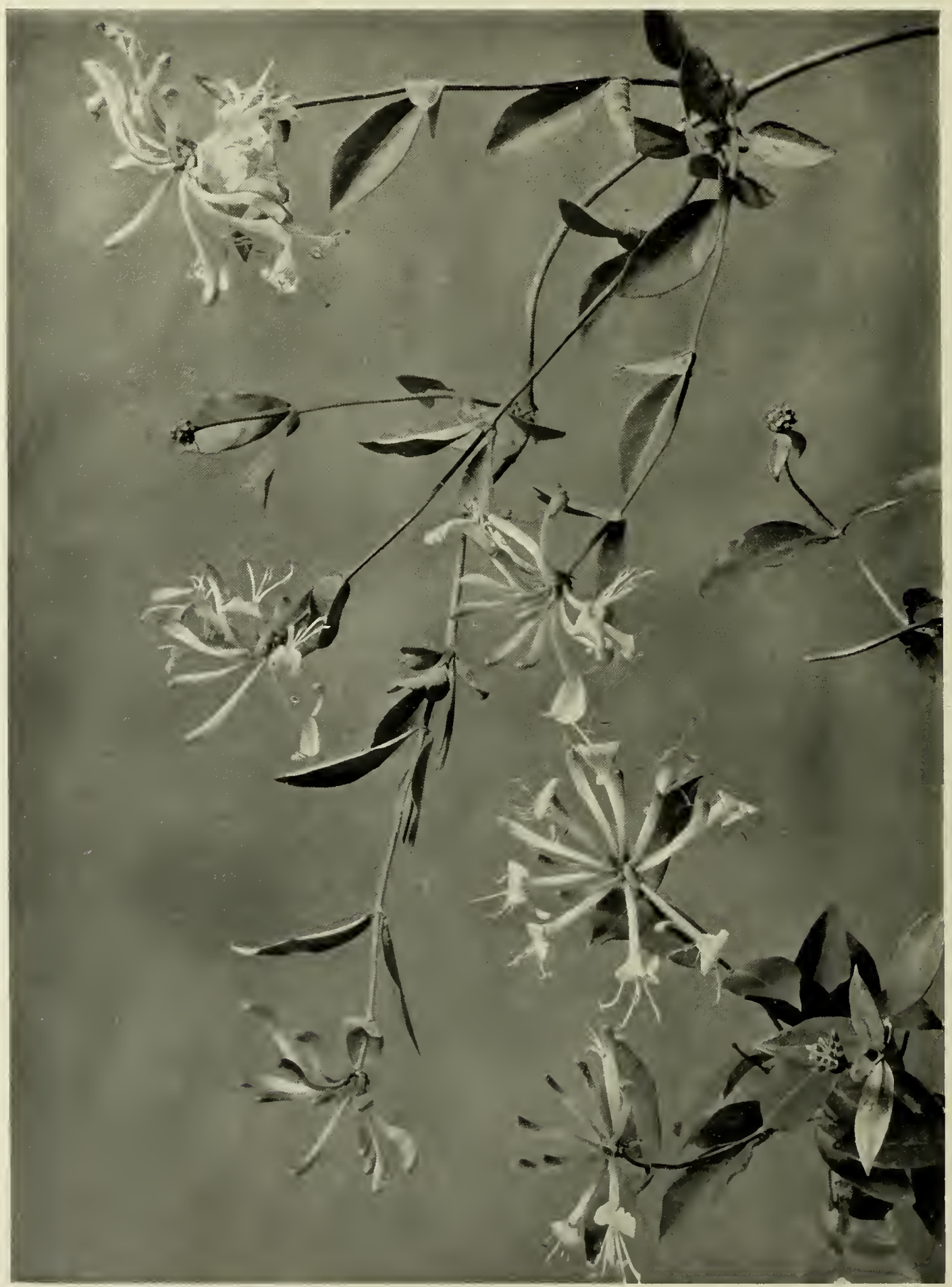

COMMON HONEYSUCKLE. 



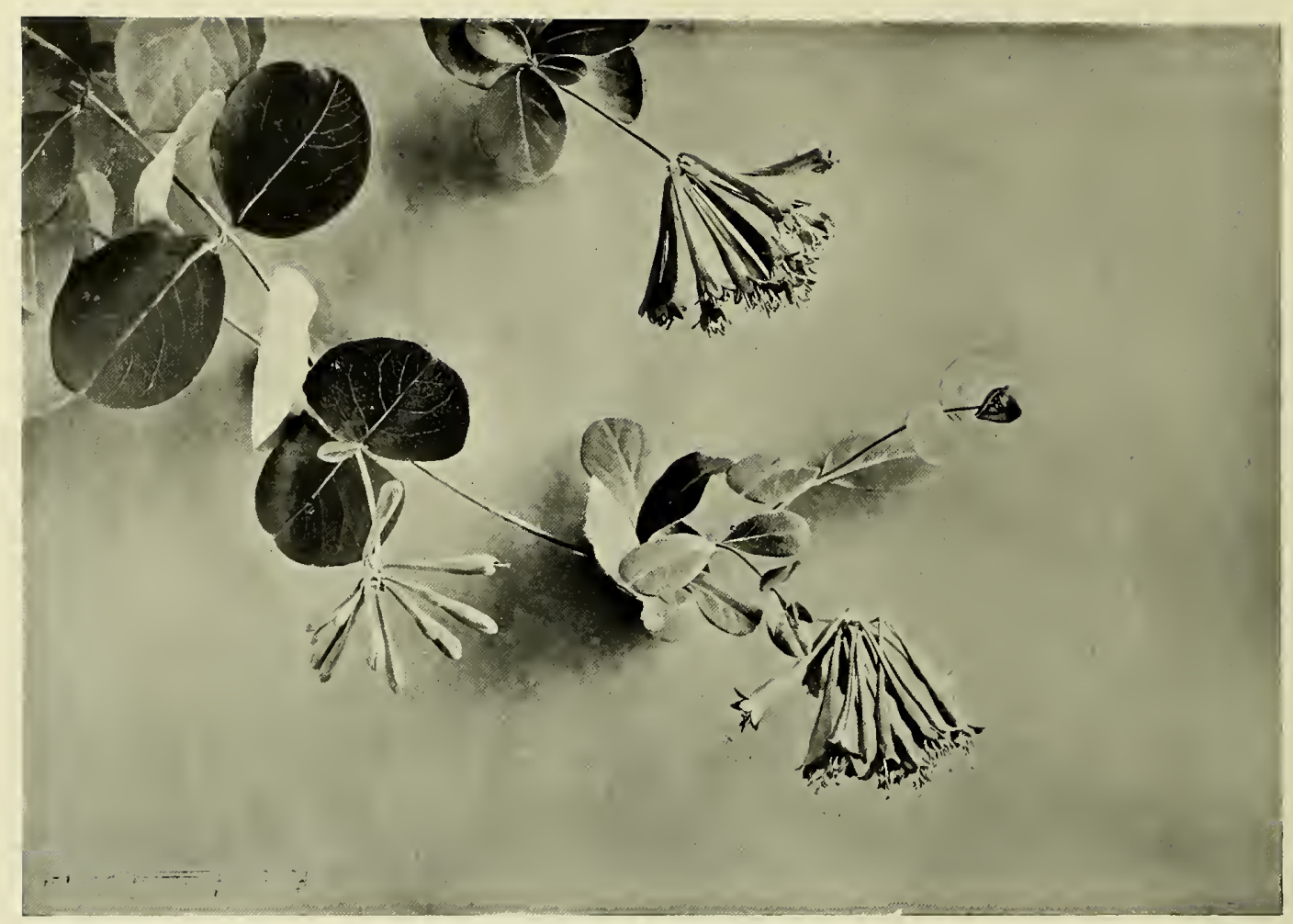

EVERGREEN HONEYSUCKLE

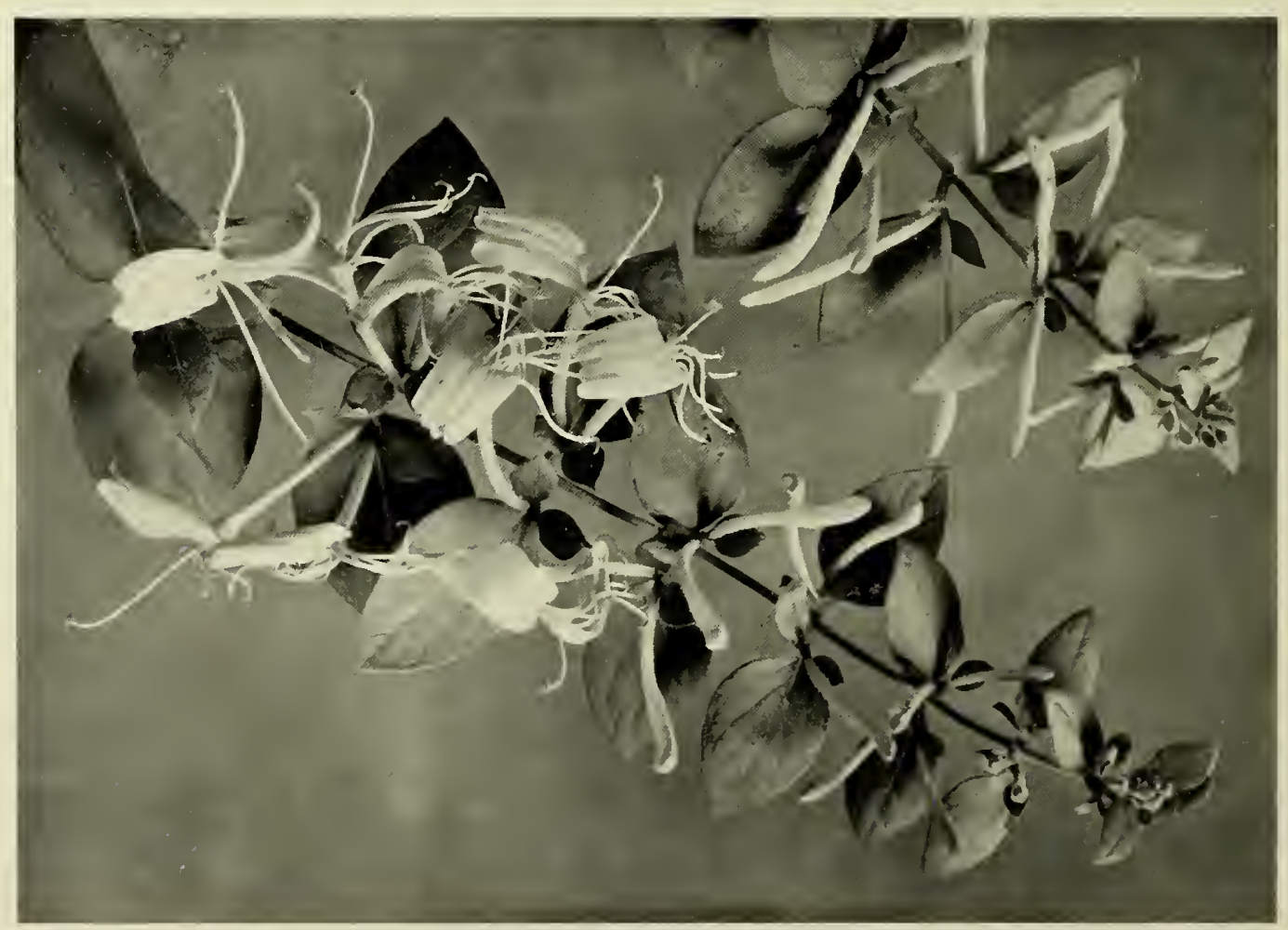

JAPANESE HONEYSUCKLE 
7I, 72, 73. HONEYSUCKLE, COMMON, EVERGREEN, AND JAPANESE.

Honeysuckle derives its name from the Anglo-Saxon honigsucle, though it is uncertain if our early and long-blossoming plant was the one referred to thereby. For many generations it was known as wood-bind, or wood-bine (A.S., veudu-bind), its favourite name with the poets, as to which Gerard says "It groweth in woods and hedges and upon shrubbes and bushes, oftentimes winding it selfe so straight and hard about that it leaveth his print upon these things so wrapped." Another old name was Caprifoil, " because it climbs like a goat." The honeysuckle blossom has a great attraction for the hawk-moth, one of the few British insects with a tongue long enough to penetrate its richly-stored recesses. It has been largely used in the arts, though its common identification with the Greek Anthemion ornament may rest on a false analogy of form. The flower was used in English heraldry in Tudor times. The Evergreen Honeysuckle was introduced from North America in 1730, and the Japanese from China in 1806 . 


\section{DAHLIA.}

The Dahlia is a member of the great Order of Composita, to which also the sunflower and chrysanthemum belong. Although it has come to be especially associated with old cottage gardens, it is a comparatively recent importation into this country, having been introduced from Mexico, its native land, only in 1789 and 1802. It was, at first, largely grown in France; and only began to be popular in England after the peace of $18 r_{4}$. Its name was chosen to do honour to a Swedish botanist, Andrew Dahl. The plant is bold and effective, but hardly graceful. Single dahlias have, however, been used a good deal, of late years, for flat pattern-wall-papers, cretonnes and the like, and a capable designer may derive valuable hints from it. 


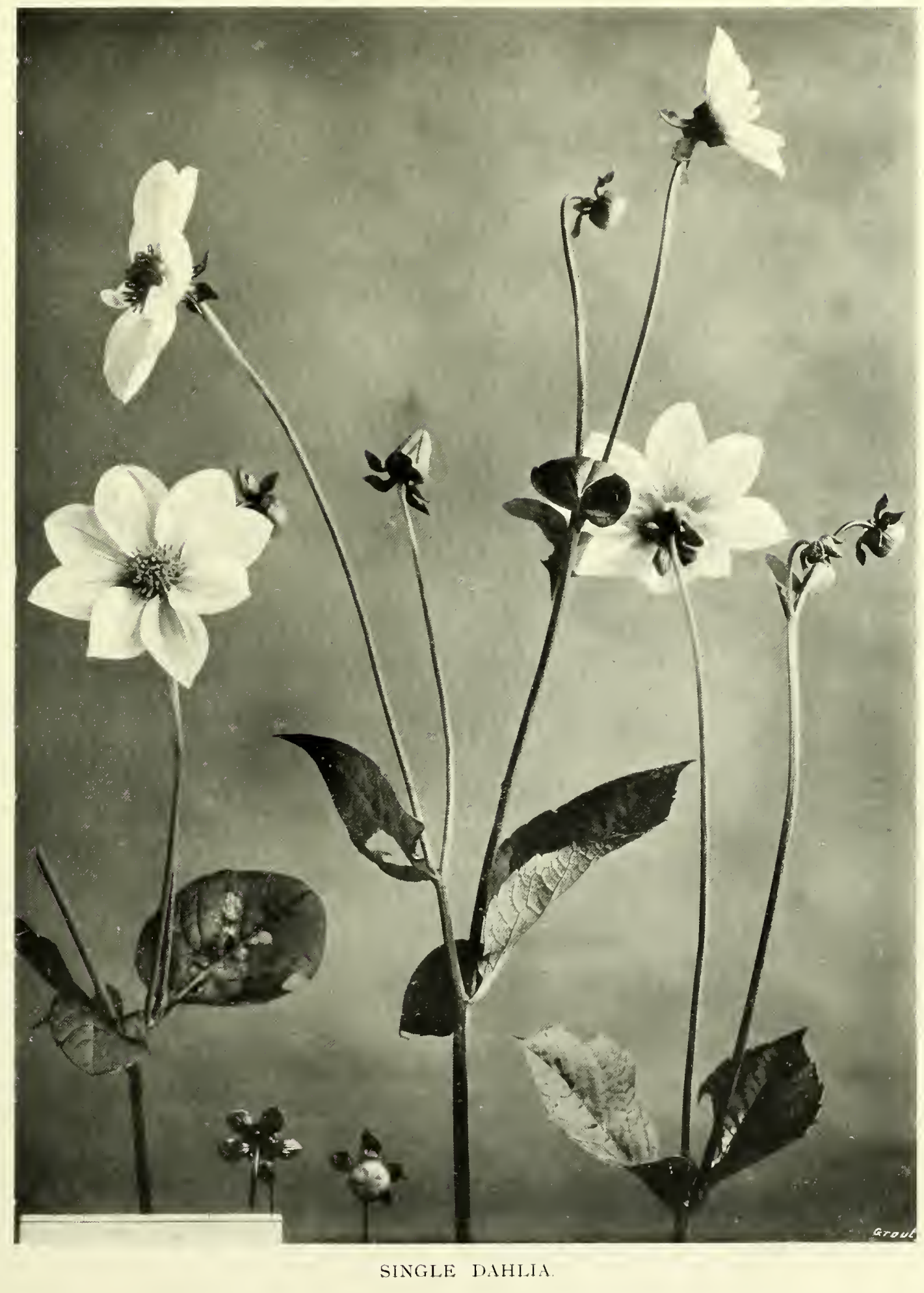





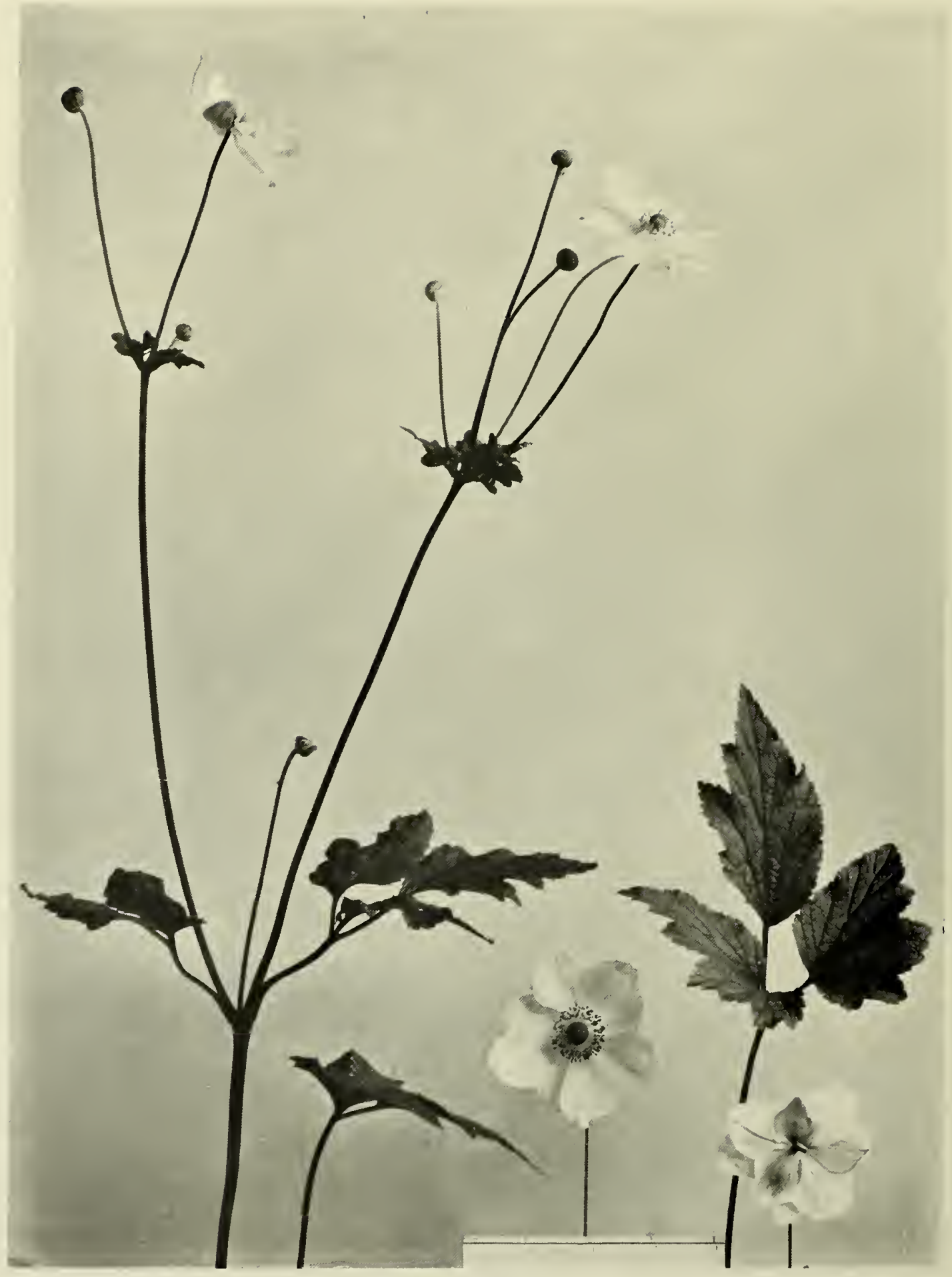

ANEMONE JAPONICA. 


\section{ANEMONE JAPONICA.}

The Anemone or Wind-flower was so called because, so the story goes, it blooms when the wind blows and flourishes especially in windy places. It was the old emblem of sickness, and was associated with the festivals of Adonis, who, after his death, was changed by Venus into this flower. The Romans used it often for chaplets. Turner in 1568 refers to it, under its ordinary name, and goes on to say- "It may be called in English Rose persely, because there groweth a floure like a single rose in the middle of this herbe, which is very lyke persely in the leaves that are aboute the rote." Gerard remarks that he had twelve varieties in his own garden and knew of many more. The Anemone Japonica, which is here reproduced, is a sturdy and beautiful flower, with a simple and effective blossom and finely serrated leaves. It is known also as the Autumn or Winter Anemone, and was brought from Japan in 1844 . 


\section{SMOOTHED-LEAVED WILLOW HERB.}

Willow Herb, or Loose Strife, was, says Pliny, first found by Lysimachus, King of Illyria. Its botanical, but ugly, name is the Great Epilobe, and its chief " virtue," according to Parkinson, " to drive away serpents or any other venemous creature, by the smoake of the hearbe burned." The smooth-leaved willow herb is one of those despised weeds which will amply repay examination by students. It has never, so far as the author knows, engaged the attention of designers; and yet the graceful and delicate backwards curve of the casing of the seed-pods, when over ripe, furnishes a beautiful and striking theme for ornament. The flower and leaf are insignificant in mass, but charming in detail ; and some of the other varieties of Loose Strife are among the most effective of those flowers that help to colour a landscape. 


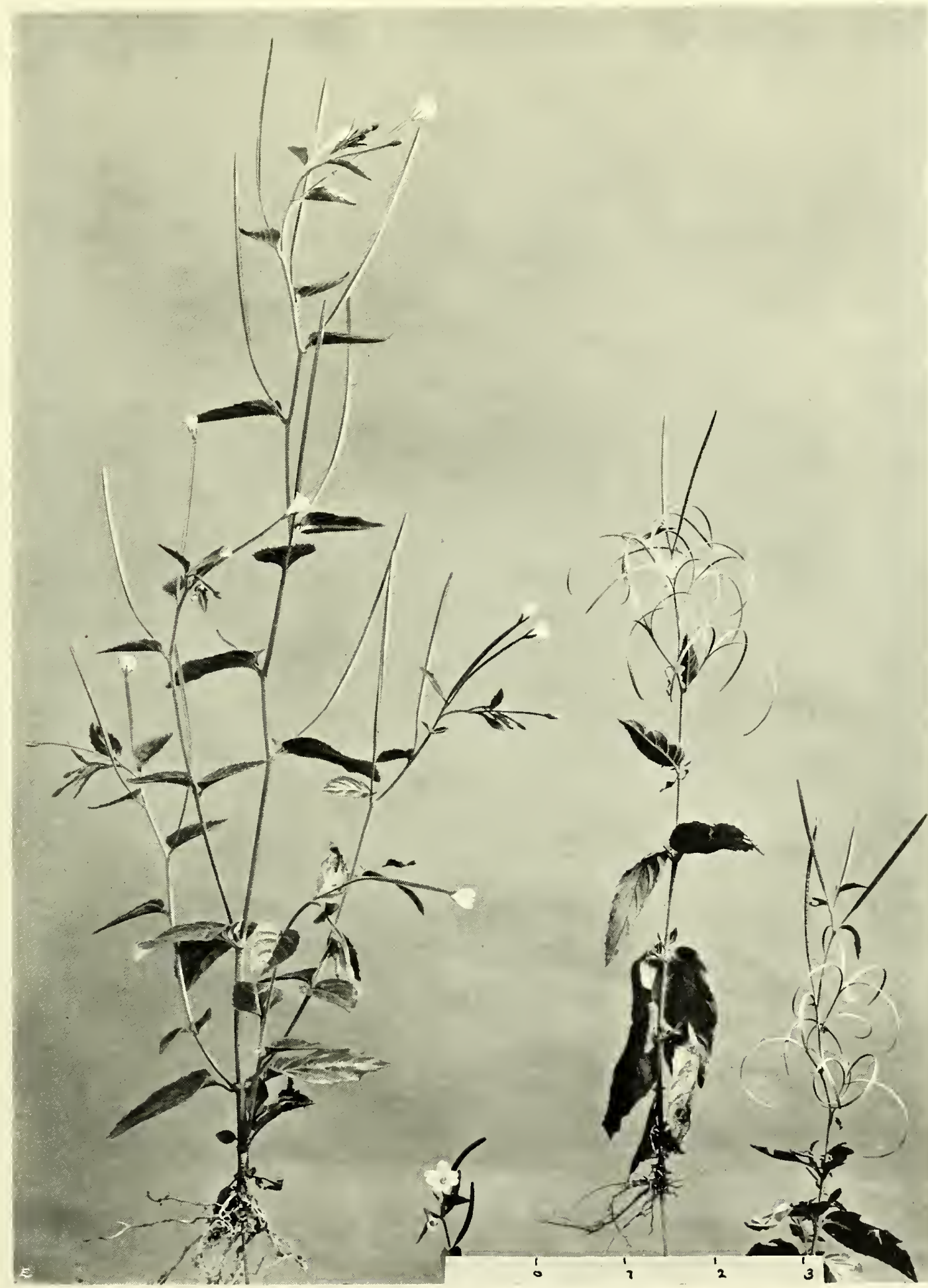

SMOOTH-LEAVED WILLOW HERB. 


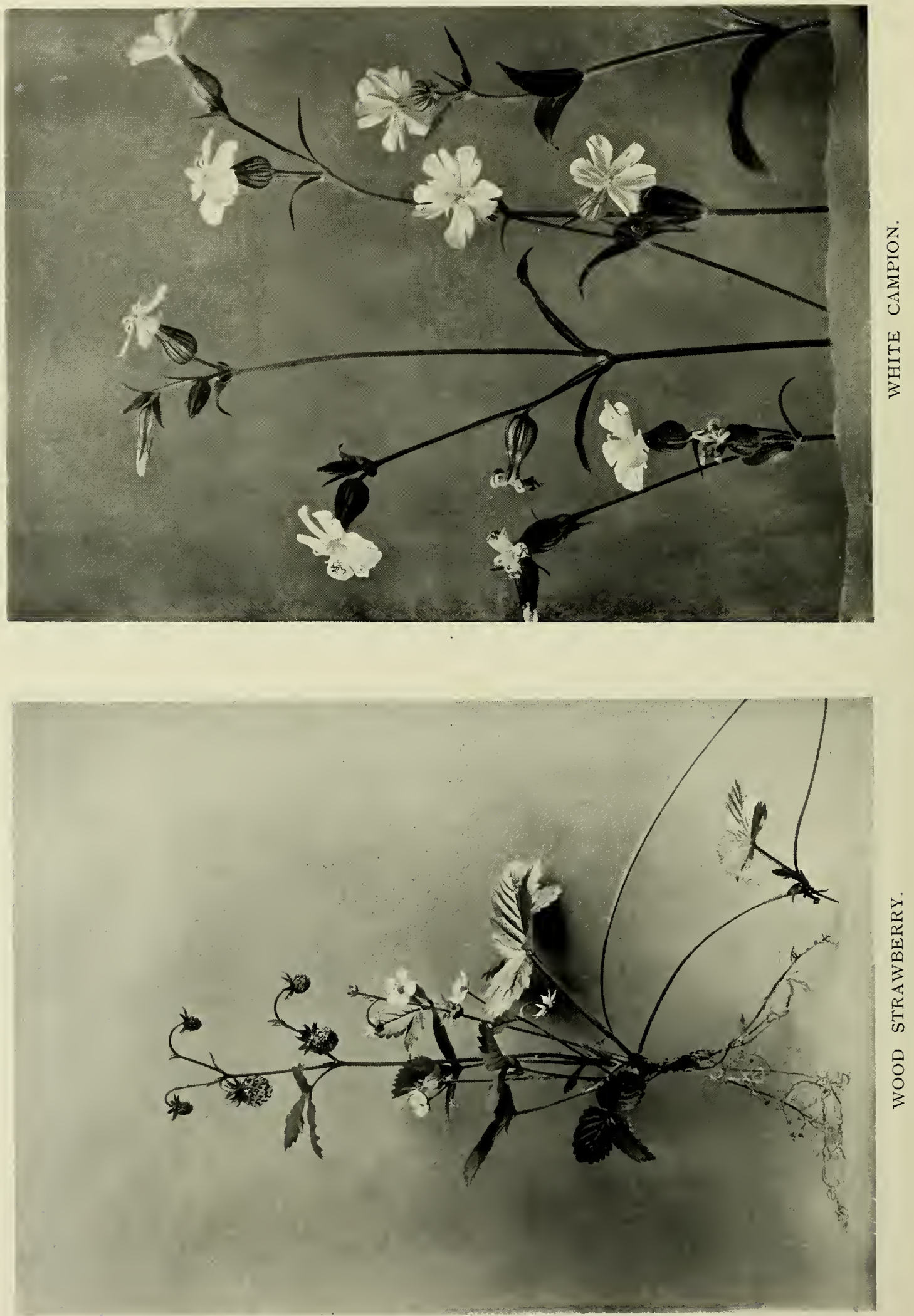


\section{WHITE CAMPION.}

Campions, White or Rose, are, as one might say, the poor relations of the Pinks, Carnations and Sweet Williams-despised as weeds by gardeners, yet very beautiful and worthy of better respect than they generally receive. White Campions were once called "White Bachelor's Buttons," though the name is now more often appropriated to another flower. Salmon says that the leaves were once used in lamps instead of wicks ; and Parkinson makes the Campion a text for an appeal for the better cultivation of wild flowers, "to be respected and nursed up with the rest, to furnish a garden of pleasure." The vase-shaped green calyx of the White Campion, so delicately lined, and surmounted by its pure white petals, furnishes an admirable study of form and proportion.

\section{WOOD STRAWBERRY.}

The Wild Strawberry or Wood Strawberry, of which Bacon says "The putting forth of certaine herbes discovereth of what Nature the ground they are forth put, is, as . . . strawberries shew grounds fit for wood."-was known to the Anglo-Saxons under its modern name, and it is parent of all the innumerable varieties of the garden fruit. The Southwark Herbal describes it under its old and beautiful Latin name, Fragraria :- "It groweth in woodes and greenes and shadowy places . . . the iuse thereof dronken with honey profyteth mervaylously: strawberyes eaten helpeth coleryke persones, comforteth the stomake and quencheth thirst." In the South of France a dish of wild strawberries is a frequent addition to a meal ; possibly for the sake of its moderating effect on the temper ; but the modern fashion, among such as have the happy chance, is to temper the fruit with cream rather than with honey. The strawberry flower is used in heraldry, as, for instance, in the arms of FraserAzure, 3 fraises argent. The whole growth of the plant, from root to fruit, is singularly graceful. 


\section{DUSKY CRANESBILL.}

The Dusky Cranesbill is one of those geraniums which are not, as Gerard says, "kept with us in gardens," but chooses its own place wherein to flourish. It presents an unusual variety of forms useful to designers, apart from its graceful growth as a whole. The vine-like foliage, the strong, bold stem, knotted at the spring of the leaves, the delicate flower, and the tapering seedvessels in various stages of development, are all full of suggestion. A kindred variety, the Crow-foot Cranesbill, was called, in the sixteenth century, Gratia Dei. 


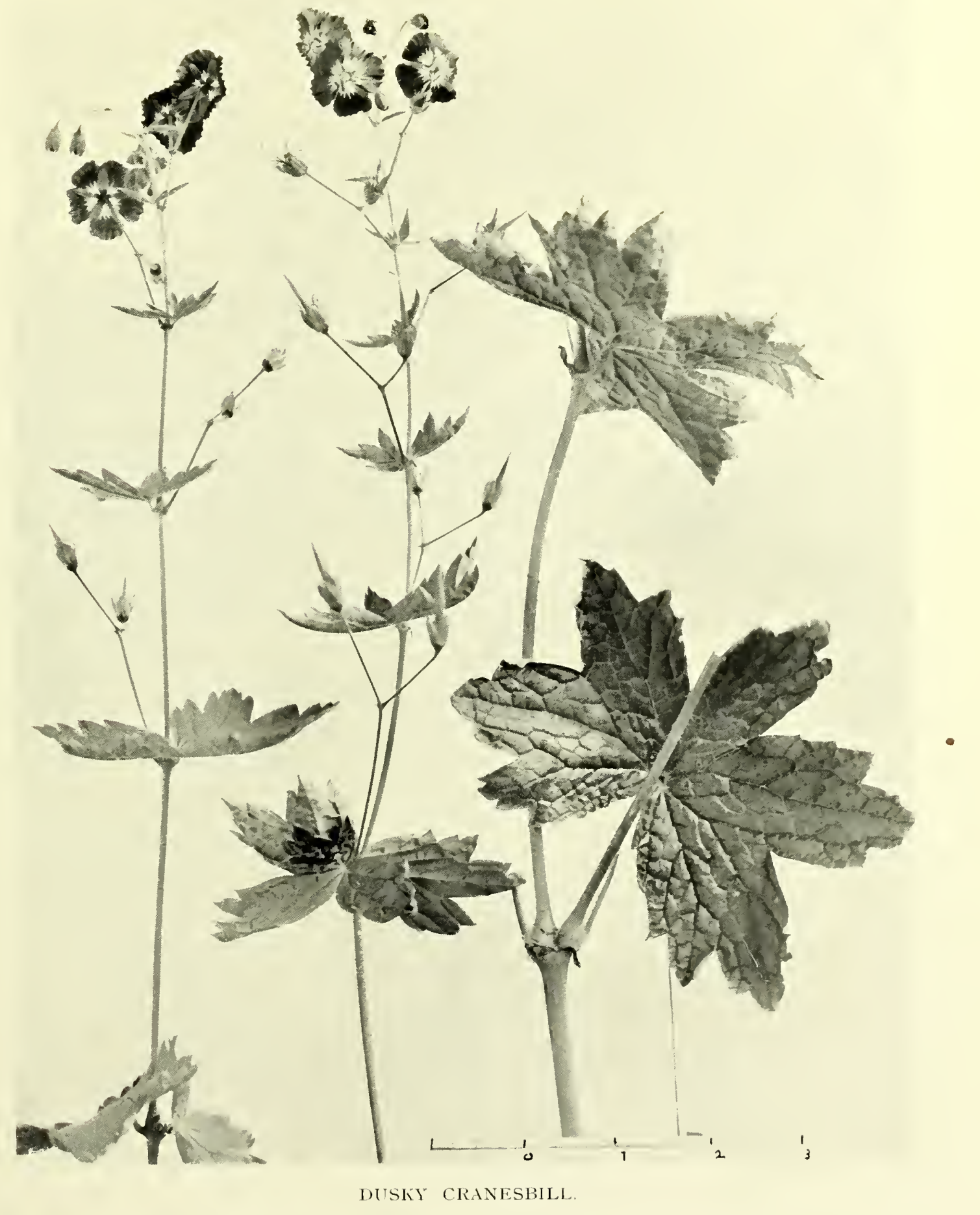



- 


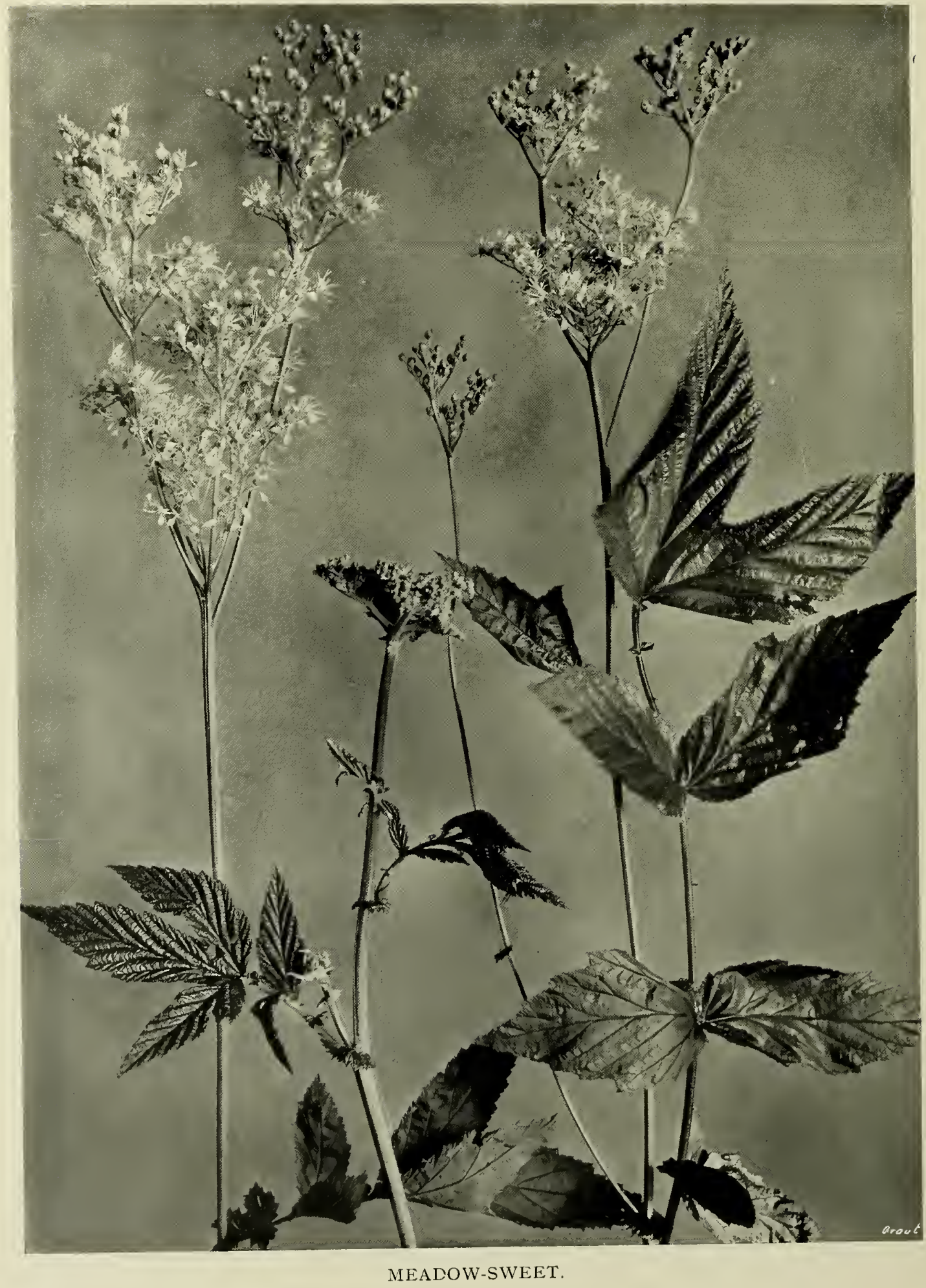




\section{8o. MEADOW-SWEET.}

In olden times meadow-sweet was one of the best-loved flowers of the country side. If Mr. W. M. Hardinge has identified it accurately in his exquisite translation from Leonidas of Tarentum, it had, with the Greeks, a mournful association-

"Ah! but, in early Spring, cull meadow-sweet, Neighbour, and weave a garland for my tomb!" Gerard, who calls it "Mede-Sweet, or Queene of the medowes," refers to one of its uses in happier vein :- " The leaves and floures farre excell all other strowing herbes, for to decke up houses, to straw in chambers, halls, and banqueting houses in the summertime; for the smell thereof makes the heart merrie, delighteth the senses; neither doth it cause head-ache, or lothsomenesse to meat, as some other sweet-smelling herbes do." The curiously crinkled leaf of the meadow-sweet is a point worth noting, which should be of service especially in modelled ornament. 
8I. WILD BEAKED PARSLEY.

The fern-shaped leaves, finely proportioned ribbed stem, and delicately spreading blossom of this plant, combine to make up an exceedingly beautiful whole, which lends itself admirably to decorative treatment. The family to which it belongs, the Umbellifera, including such well-known forms as the Carrot, Celery and Hemlock, are all remarkable for their foliage, and may be studied from this point of view. 


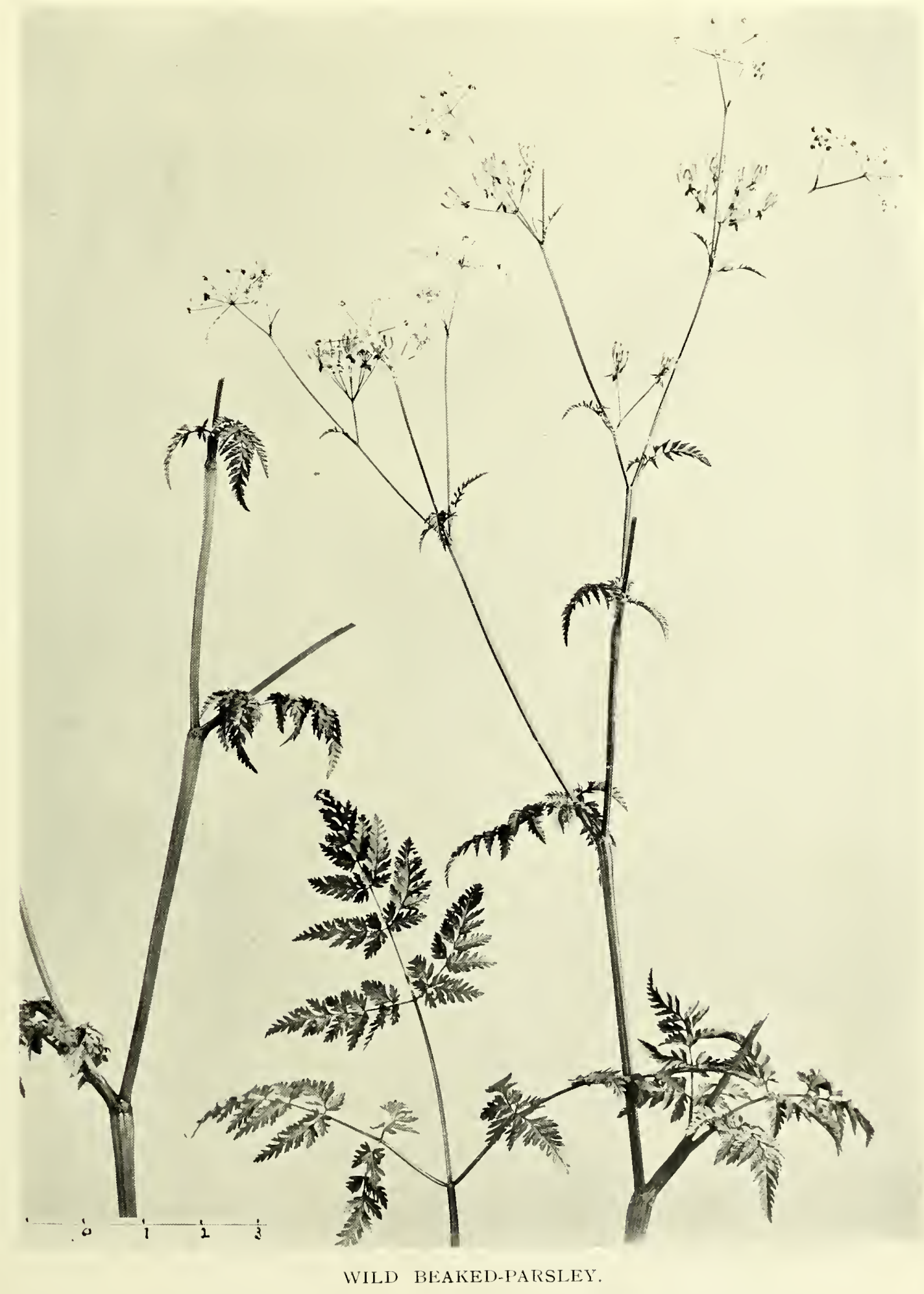





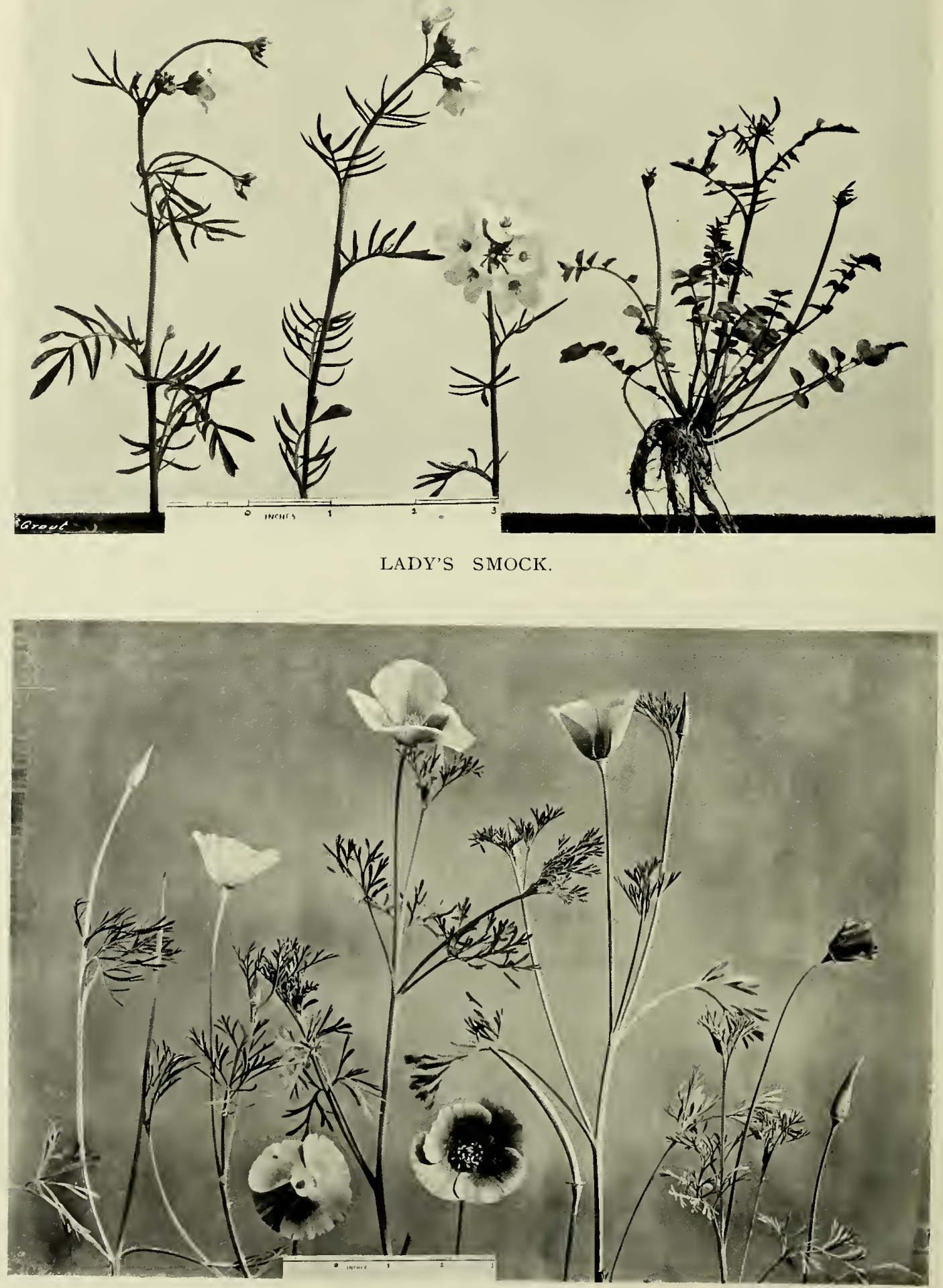

ESCHSCHOLTZIA 


\section{LADY'S SMOCK.}

"These," says Gerard, "flower for the most part in Aprill and May, when the cuckowe doth begin to sing her pleasant notes without stammering." Thereby comes one of the old names of the Lady's Smock- "Cuckowe Flowers." The same writer says that "in Northfolke" they are called Canterbury Bells ; but, that as they had the former name " at Namptwich in Cheshire where I had my beginning," so did he choose to call them. This flower-as, "Ladysmock all silver white," is mentioned by Shakespeare, in the Spring Song of "Love's Labour's Lost" ; and as "Cuckoo Flowers," it is among the "idle weeds" that crowned King Lear. Izaak Walton notices the custom of twining it into May garlands, with lilies, culverkeys and cowslips ; and Chatterton also does it honour. It used to be eaten much as is watercress, to which it is botanically allied. It is known sometimes as Cardamine.

\section{ESCHSCHOLTZIA.}

The Eschscholtzia is one of the most interesting members of the Poppy family. It was introduced into England in I826, from California, where it is very abundant and so great a favourite that it has, in spite of its cumbersome name, been adopted as the floral emblem of the State. The orange flower of the Eschscholtzia, its graceful foliage, and especially the characteristic form of the buds, and the blossom when folded up on a cloudy day, deserve more attention from designers than they have yet received. For the decoration of tiles, or patterns of a like kind, this flower is especially suitable. 
84, 85. LOVE-IN-A-MIST, FLOWER AND SEED.

The chief literary characteristic of this charming flower lies in the curious and varied assortment of names which it has accumulated. Besides that given above, it has also been called Love-in-a-Puzzle, Devil-in-a-Bush, Garden Fennel Flower, and, by the French, Venus's Hair, Spider's Claw, Blue Beard, etc. It is a native of the South of Europe, but was known in England certainly as long ago as the year 1570 ; and, although, as in literature, it has made but a small appearance in the arts, the fine treatment of it in some recent enamelled jewellery by $\mathrm{Mr}$. Henry Wilson, shows that it possesses great possibilities in this direction, if tastefully and intelligently used. 


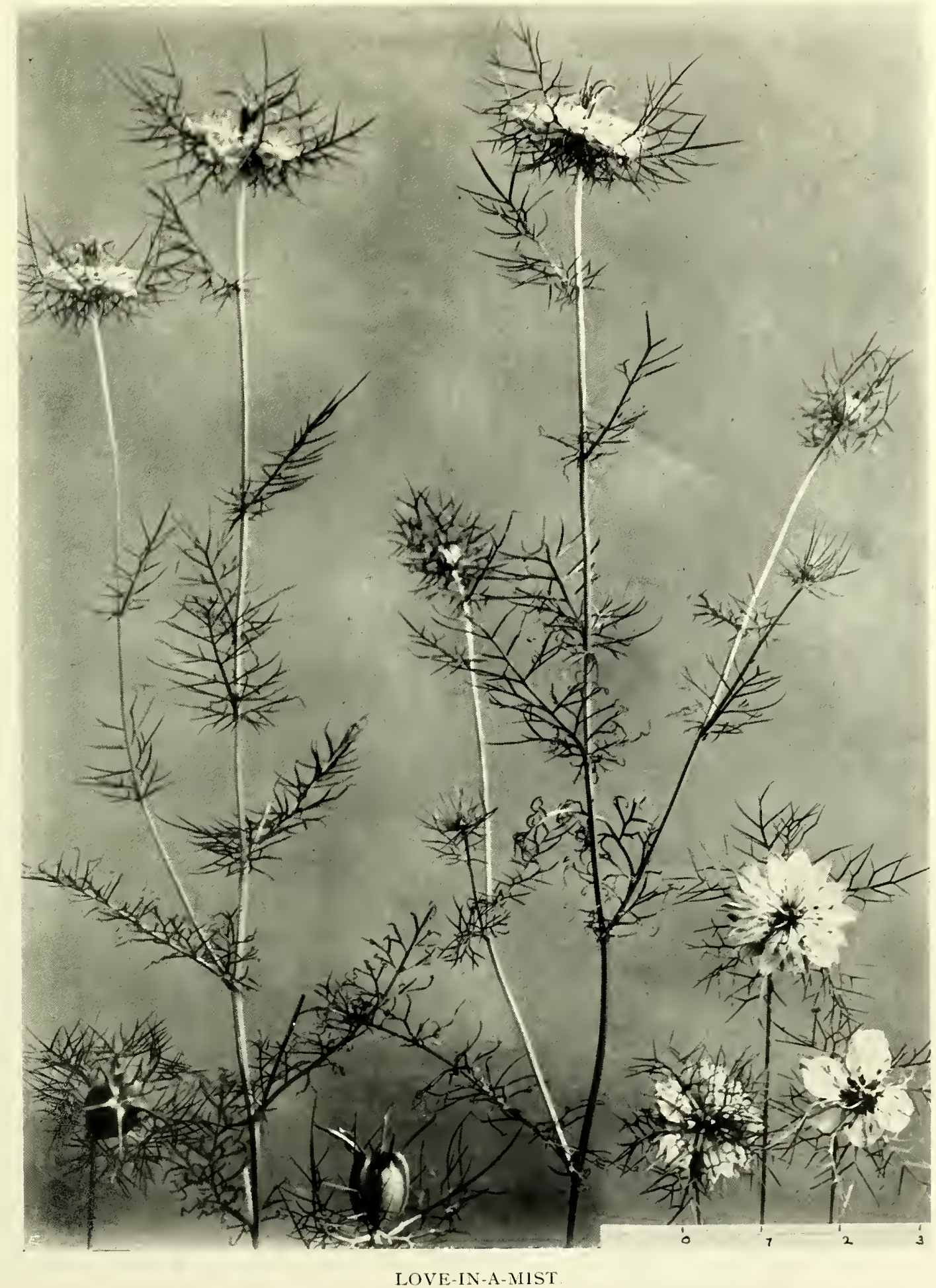





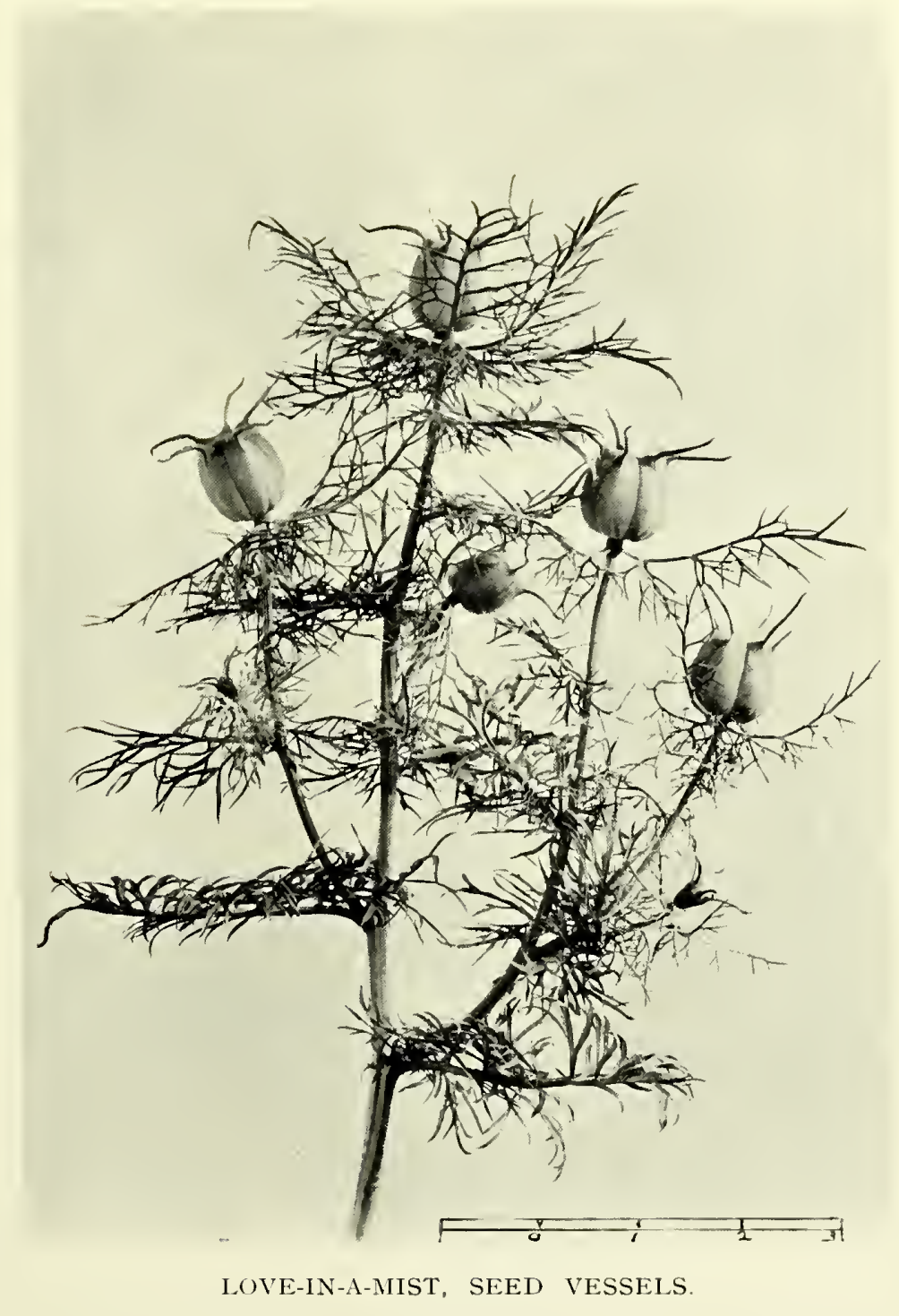






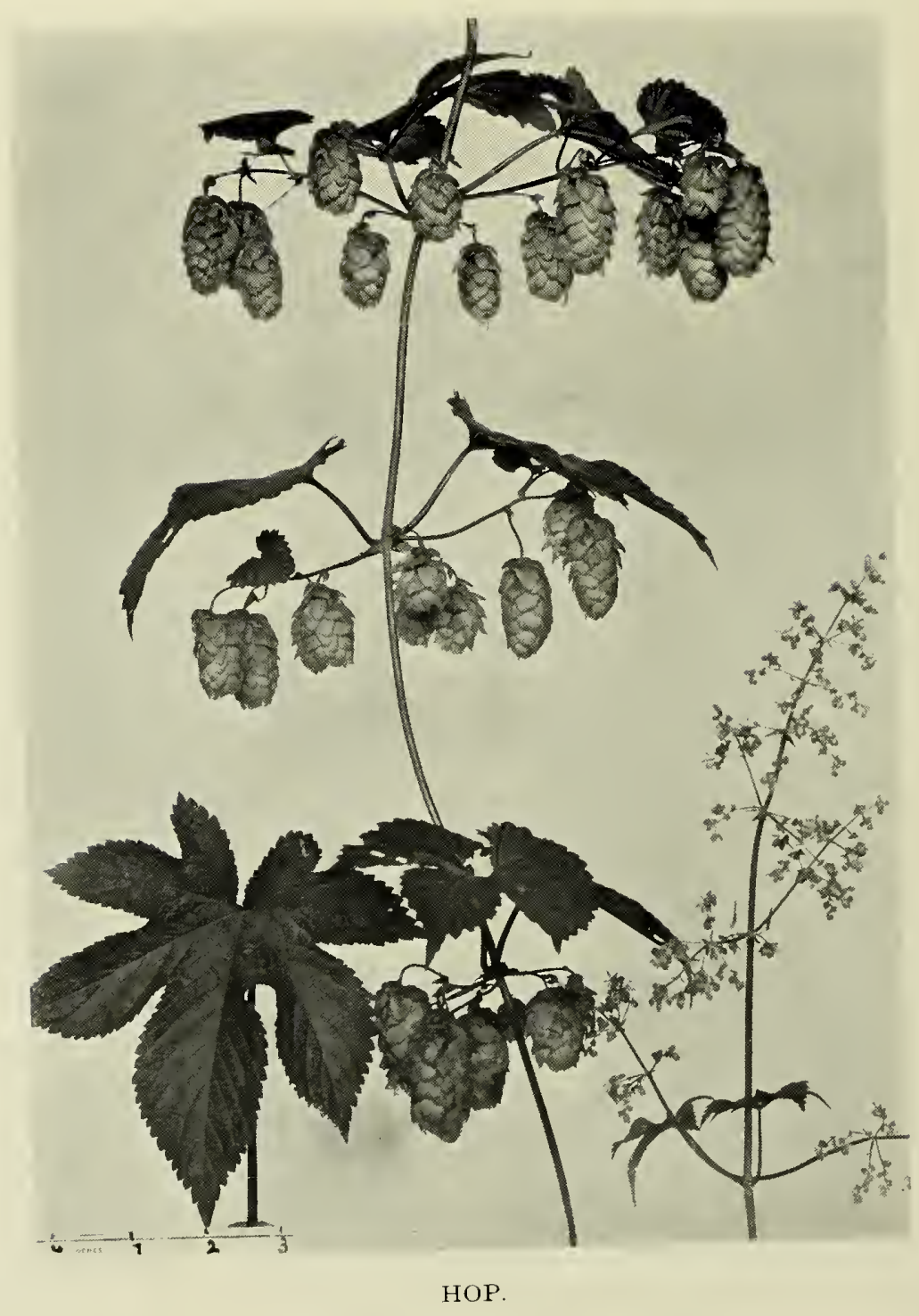




\section{HOP.}

"Lupulus," says the Southwark Herbal, " is an herbe that groweth on hedges and rampeth in maner of an herbe called bryony or white vine, and is called hoppes, ye leves thereof be lyke nettles and hath sharpe savour and tarte. And they be put in a drynke called dowble beare." Gerard, who distinguishes between beer and ale, also describes this beautiful plant at length. It " ioyeth in a fat and fruitfull ground," and "doth live and flourish by embracing and taking hold of poles, pearches and other things upon which it climeth." The hop is used in heraldry -chiefly as hop-vines and hop-poles, as, for example, in the canting arms of Hobillion, Houblon, Boorman, etc. It has also been employed a good deal in black and white decorative drawing, but its evident possibilities for large flat pattern have not yet been nearly exhausted. 


\section{CANDY-TUFT.}

The Candy-tuft is an old flower, and is mentioned both by Pliny and by Dioscorides. It derives its name from the Island of Candia, and is referred to by Gerard as a rare plant. In France it was considered to be the floral symbol of architecture, " because," says a writer of a century ago, "its flowers are disposed in stories from the bottom of the stalk to the top, which is thought to produce a resemblance to the pretty open columns of one of the most delicate orders of architecture." Candy-tuft seed once was eaten in the place of mustard, except that it was not pounded. 


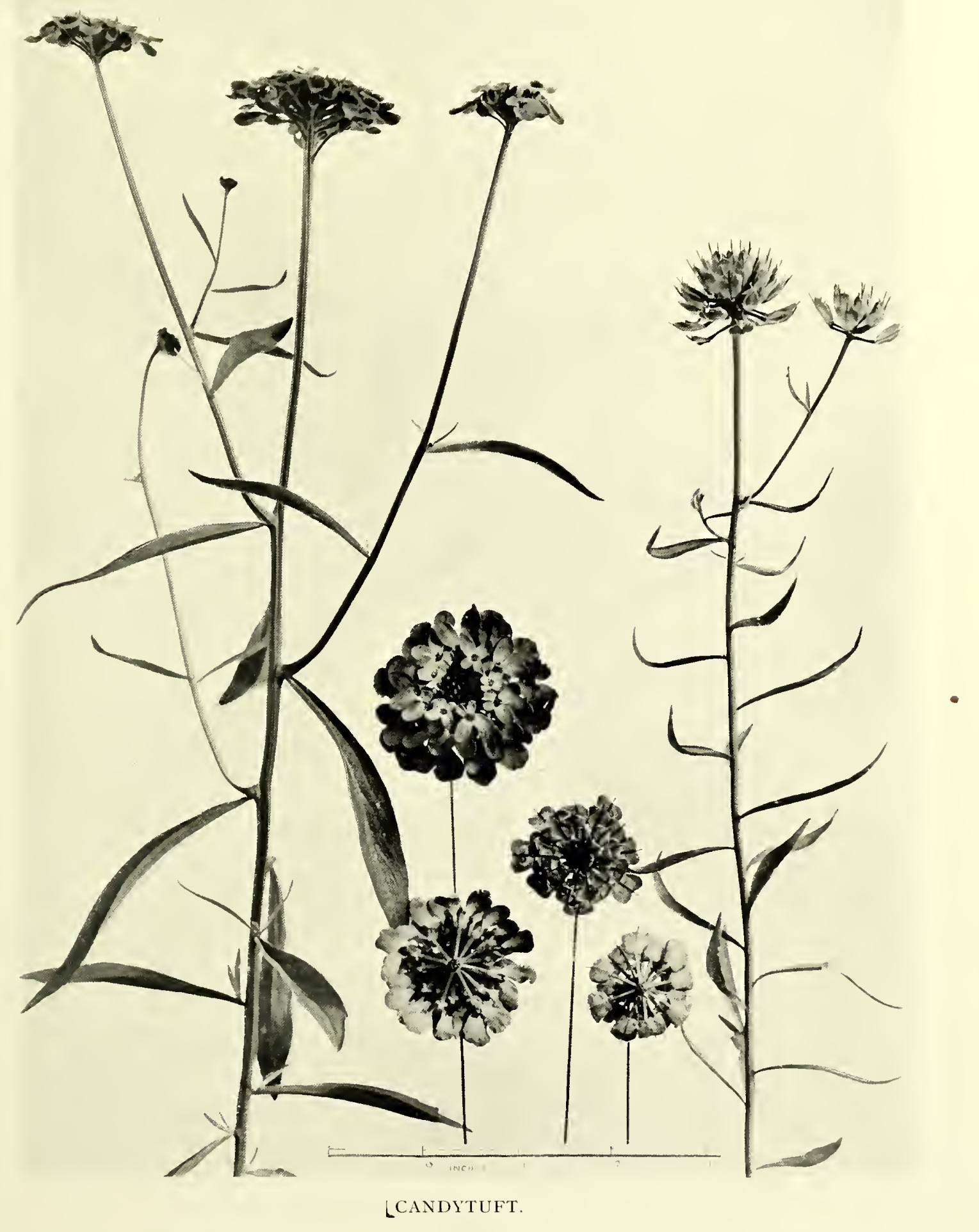





$$
\text { - }
$$




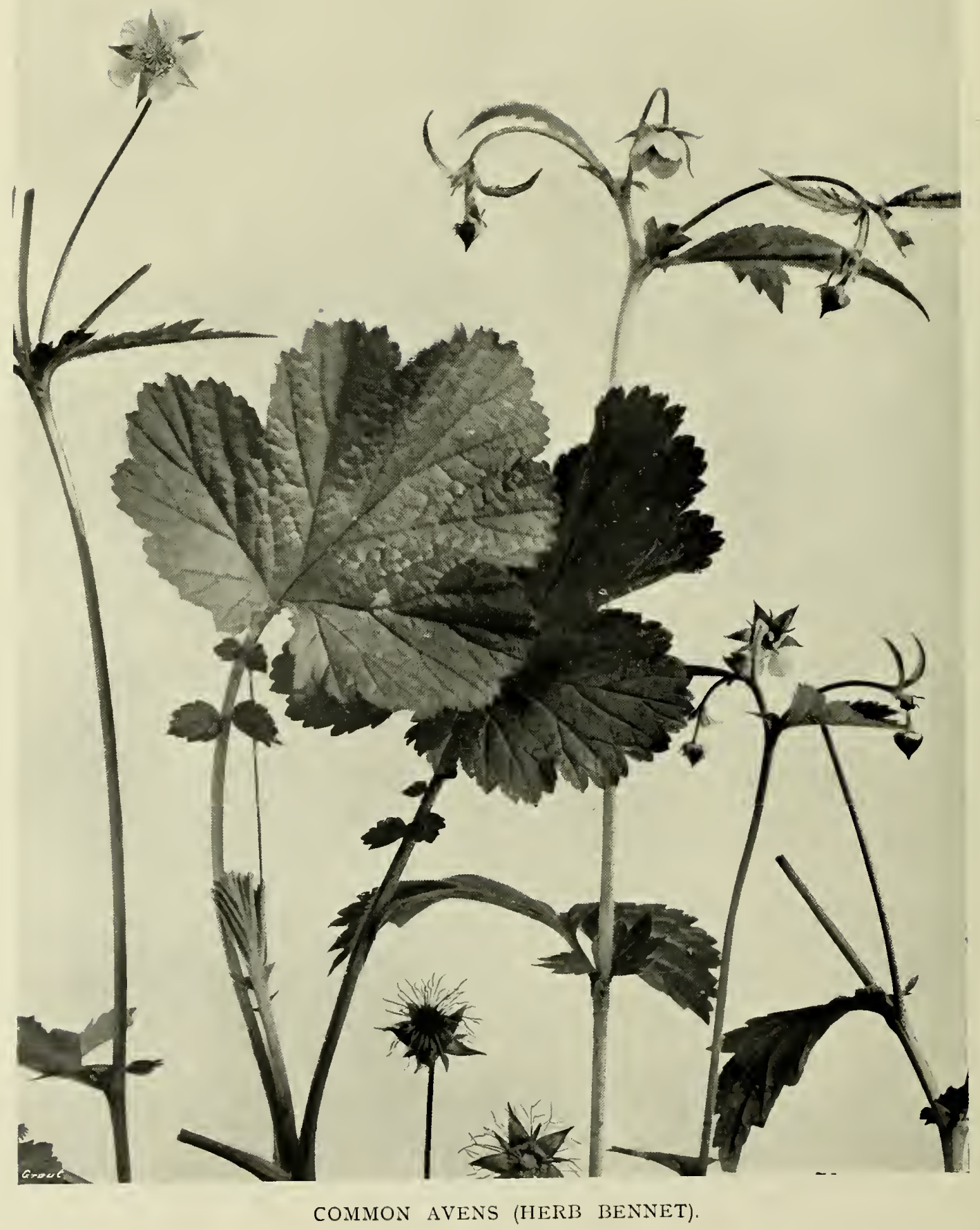




\section{COMMON AVENS.}

Of Common Avens, says Gerard, "it is generally called nowadayes Caryophyllata . . . from the scent of the roote so neare resembling Cloves (Caryophilli); yet some have called it Herba Benedicta, of the excellent or blessed qualities thereof." The latter term has survived in Herb Benet, by which it is now often known. Both the Common Avens and the nearly-related Water Avens supply a large range of beautiful forms. The foliage is eminently suitable for sculptured ornament, and has been used freely in York Minster and elsewhere for this purpose ; and attention may be drawn to the five-pointed star-shaped blossoms and graceful curve of the grouped buds from the main stem. 
89. WATER AVENS (HERB BENNET).

For note see page 77 . 


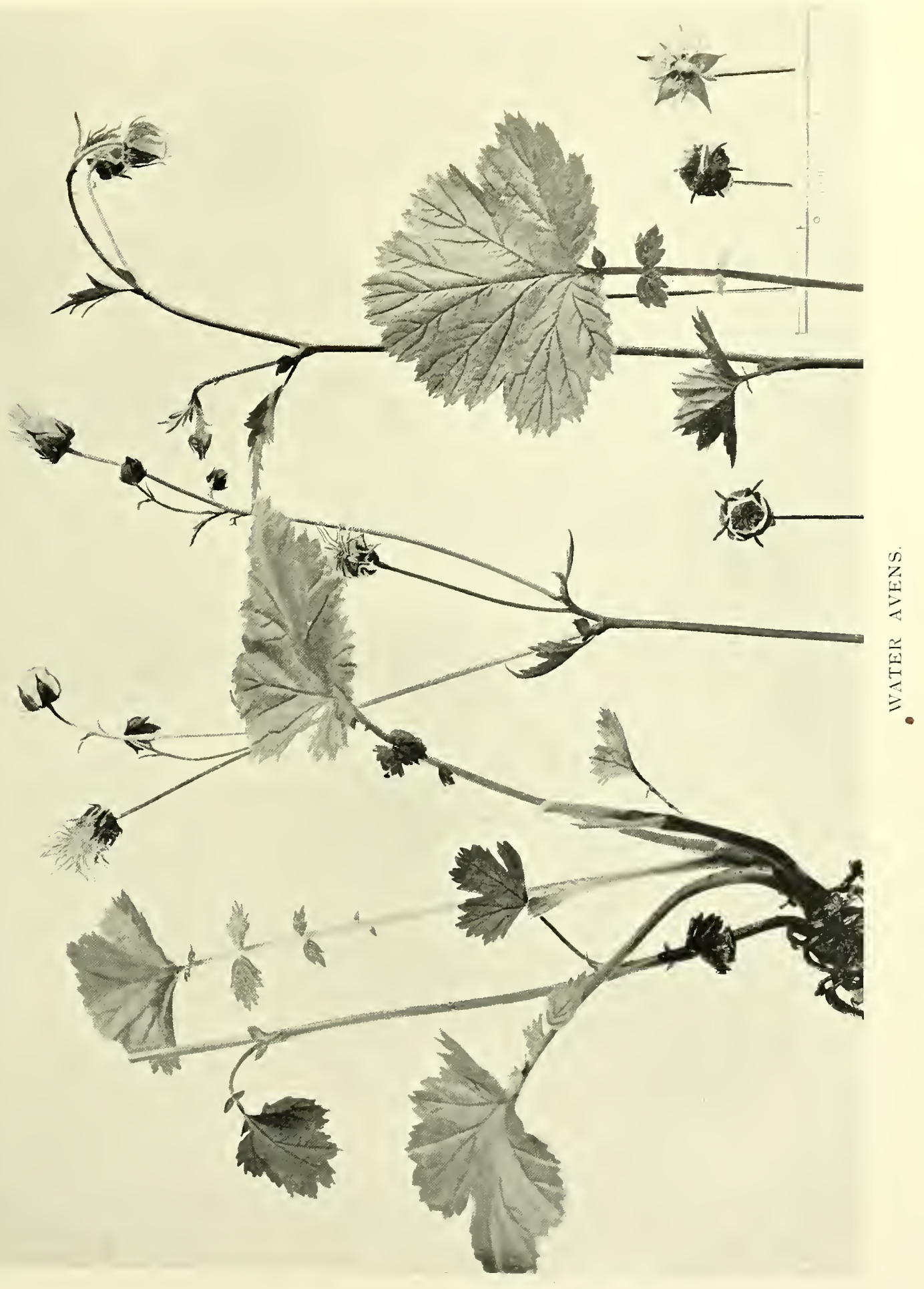






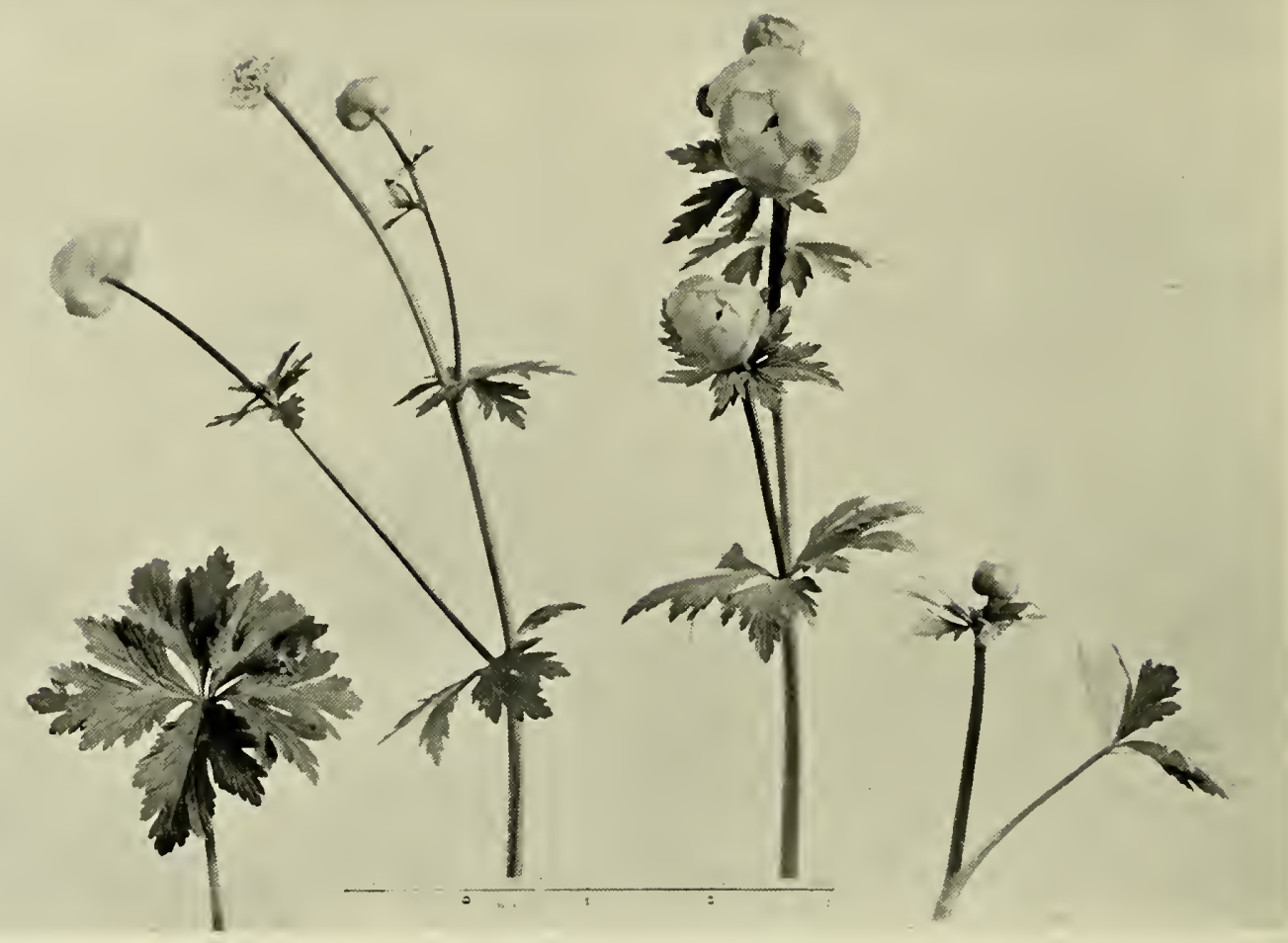

GLOBE FLOWER

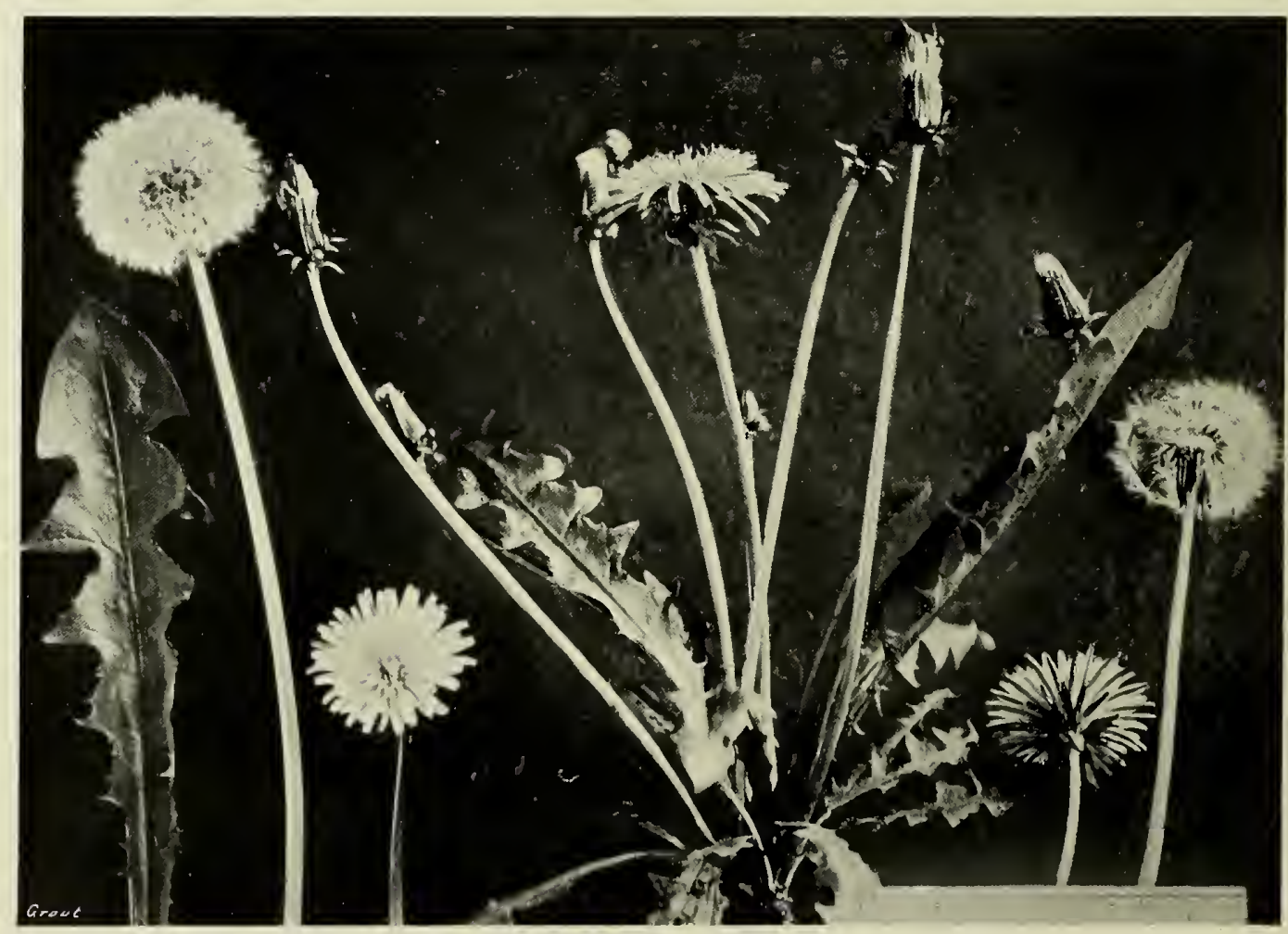

DANDELION. 
90, 91. GLOBE FLOWER AND DANDELION.

Of the Globe Flower, Globe Crowfoot, Troll flowers or Locker gowlons-the last, a cryptic term-Gerard says that it "groweth in most places of York and Lancashire and other bordering shires of the North Countrey, almost in every medow, but not founde wilde in these southerly or westerly parts of England that I could ever understand of." Since his time it has spread freely, and now is common everywhere. The Dandelion-Italian, Dente de leone-lion's tooth-is too well known to need detailed description. The clusters of seed are called, by children, "What o'clocks," it being with them a firm article of belief, that the number of puffs required to blow away all the seeds is that of the time of day. It is curious to note that Parkinson recommends them as a "sallet"-a word so much better than the alien, salad; and to reflect that this use of the herb, as of sorrel and others, was once so common in England, but comes now as an importation by French cooks. Gerard artlessly observes that "a decoction made of the whole plant helpes the yellow jaundice." Its use as a medicine still persists among old-fashioned people. 
92. CREEPING BUTTERCUP.

Of the Creeping Buttercup, King Kob, Gold Cups, Gold Knobs or Butter floures, he remarks-" "There be divers sorts of kinds of these pernitious herbes comprehended under the name of Ranunculus or Crowfoot, whereof most are very dangerous to be taken into the body." Anyone whose garden is infested with the "pernitious herbe" will hardly disagree with his epithet-yet the children would be sad to lose the traditional companion of the daisy; and the pretty blossom with which they practise divination as to one's appetite for butter. The leaves of both flowers are finely shaped. 


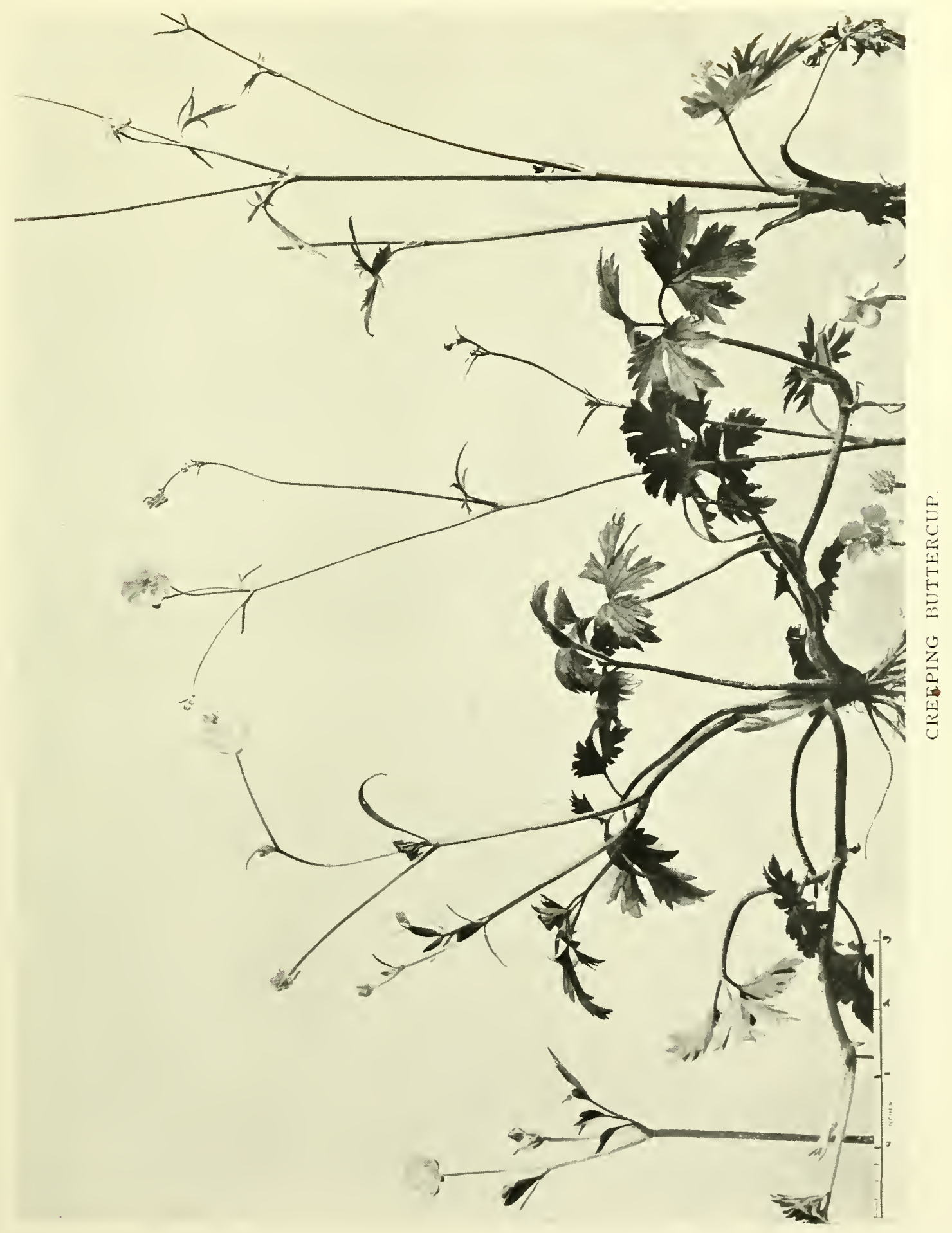





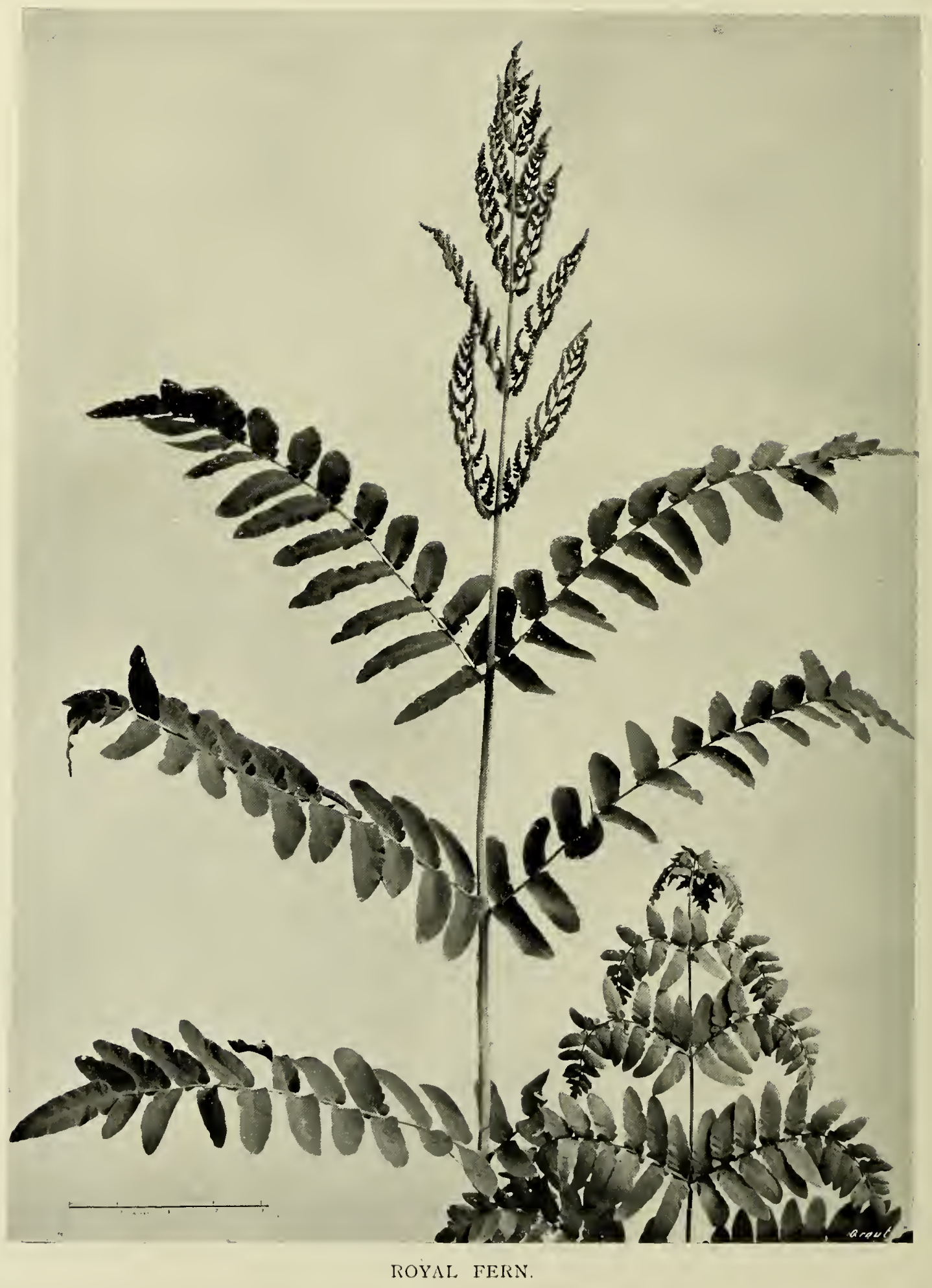




\section{ROYAL FERN.}

The Royal Fern, Water Fern, "St. Christopher's Herbe," Osmund Royall, or Osmund the waterman" are the names by which Gerard refers to the noblest and now, unhappily, almost the rarest of British ferns. The allusion to St. Christopher may have been suggested by the watery nature of the locality in which the fern occurs; that to Osmund-probably St. Osmund of Salisbury, is very obscure. Gerard gives a fine description of the Royal Fern-" a great triangled stalke 2 cubits high, beset upon each side with large leaves spred abroad like wings. The rote is great and thicke . . . having in the middle of the great and harde woody part thereof, some small whitenesse, which hath been called the heart of Osmund the Waterman." The fern can still be found in Cornwall, but a hard week's search in its once most favoured spots recently yielded but two specimens. In Gerard's time it grew upon Hampstead Heath, but had disappeared therefrom when Johnson's edition of his herbal was published. 


\section{4, 95. RUSHES.}

Reeds and Rushes supply a pleasant embroidery to watercourses or standing pools. In the East they were a sign of fertility ; and are so spoken of by Isaiah in one of his most splendid prophecies-" And the parched ground shall become a pool, and the thirsty land springs of water ; in the habitation of dragons, where each lay, shall be grass with reeds and rushes." And in Sabrina's Song in Comus we have

"By the rushy-fringed bank,

Where grows the Willow and the Osier dank

My sliding chariot stayes."

Parkinson describes the "Rush without any joynt therein, whereupon came the proverb Nodum in scirpo quarere, to seek a knot in a rush, spoken of such as are scrupulous and doubtfull whereof no scruple or doubt neede to be made." The flowering rush was called by Gerard "Water Gladioll," following a false analogy which had betrayed several of his authorities. The old use of rushes to strew the floors of living rooms needs no more than bare reference. Rushes were used as devices by Don Roderigo d'Avalos, and by the Colonna family after their banishment from Rome; they were represented as being buffeted by wind and waves, with the motto Flectimur non frangitur undis. 


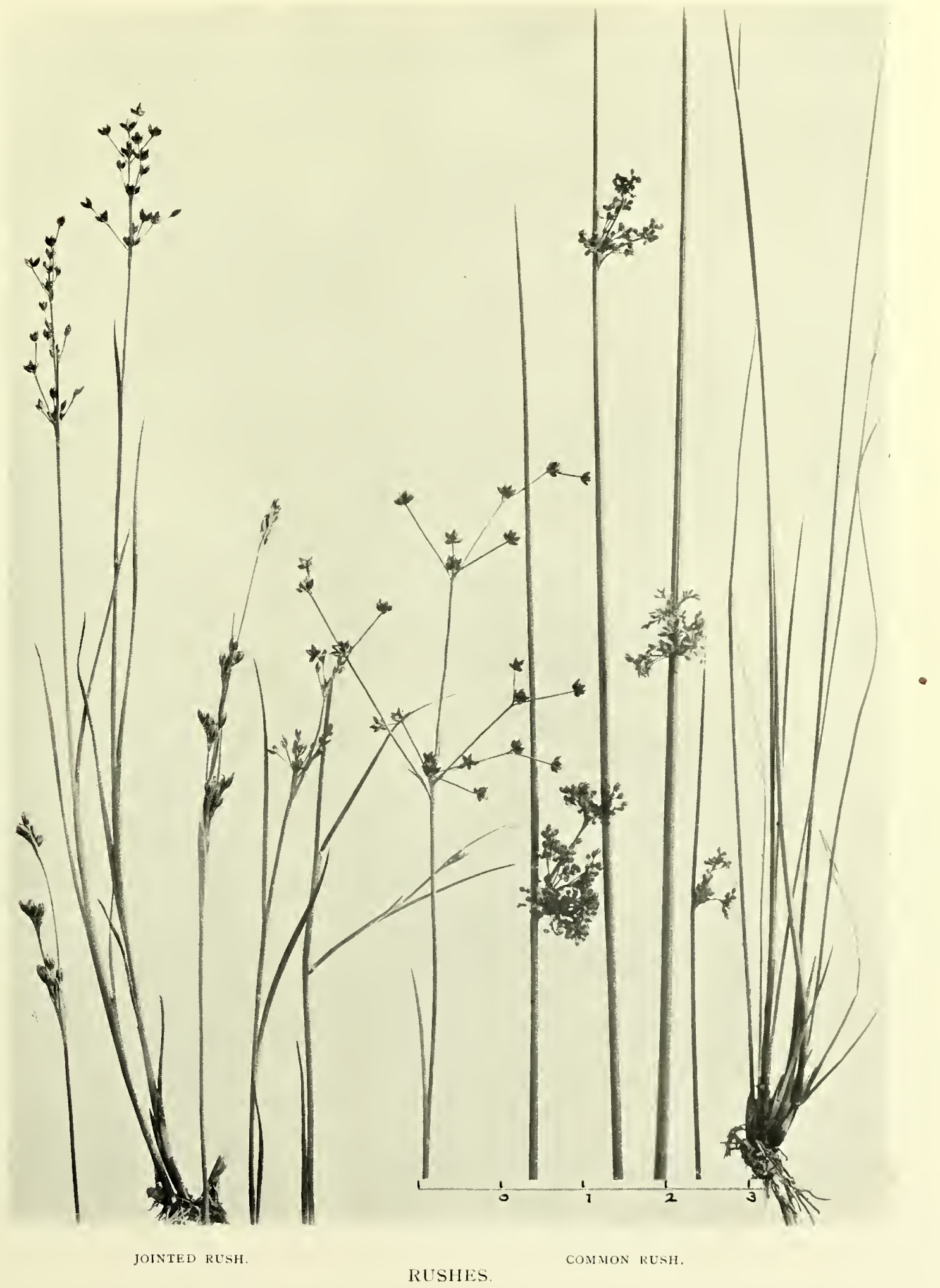





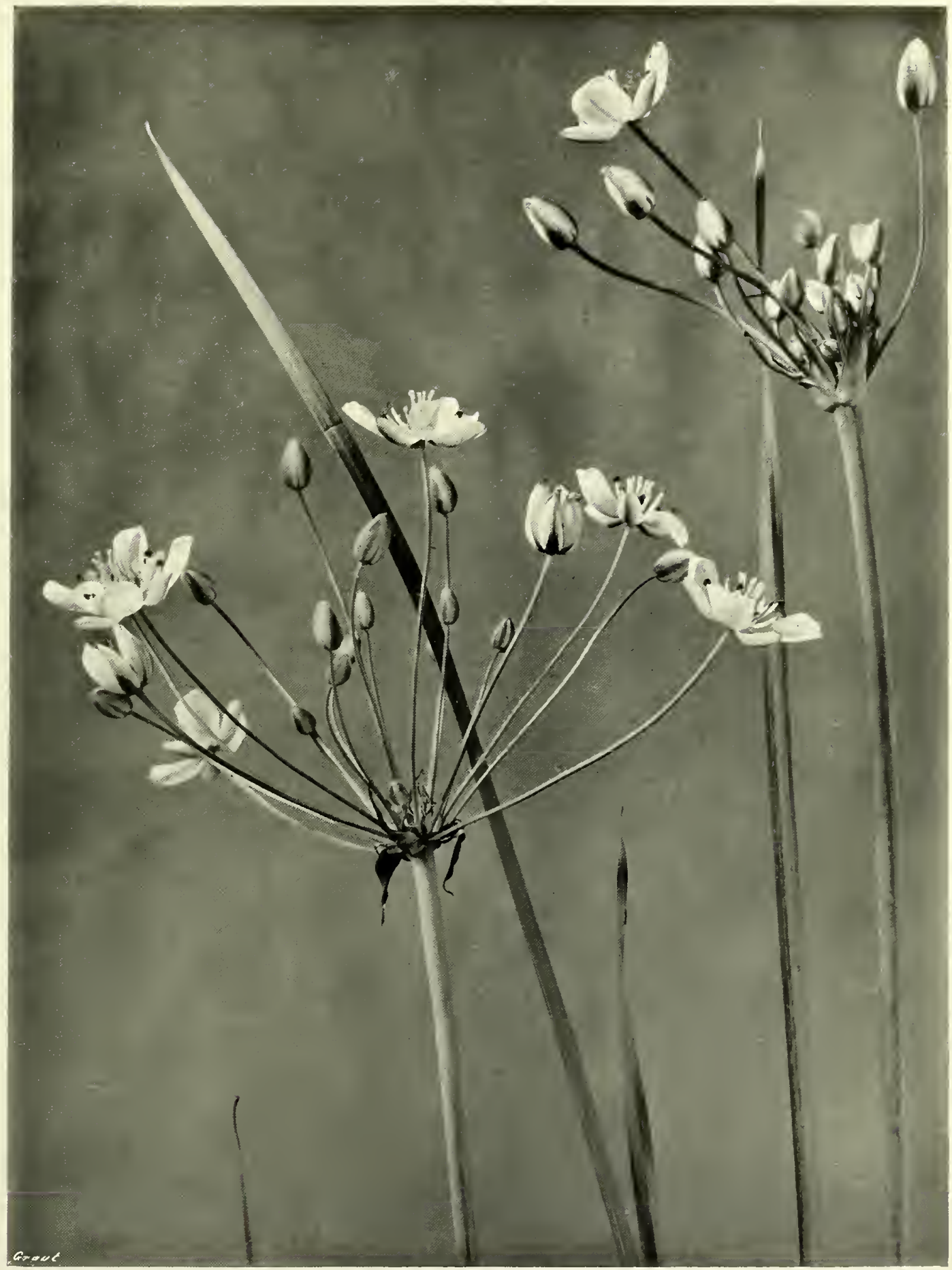

FLOWERING RUSH 




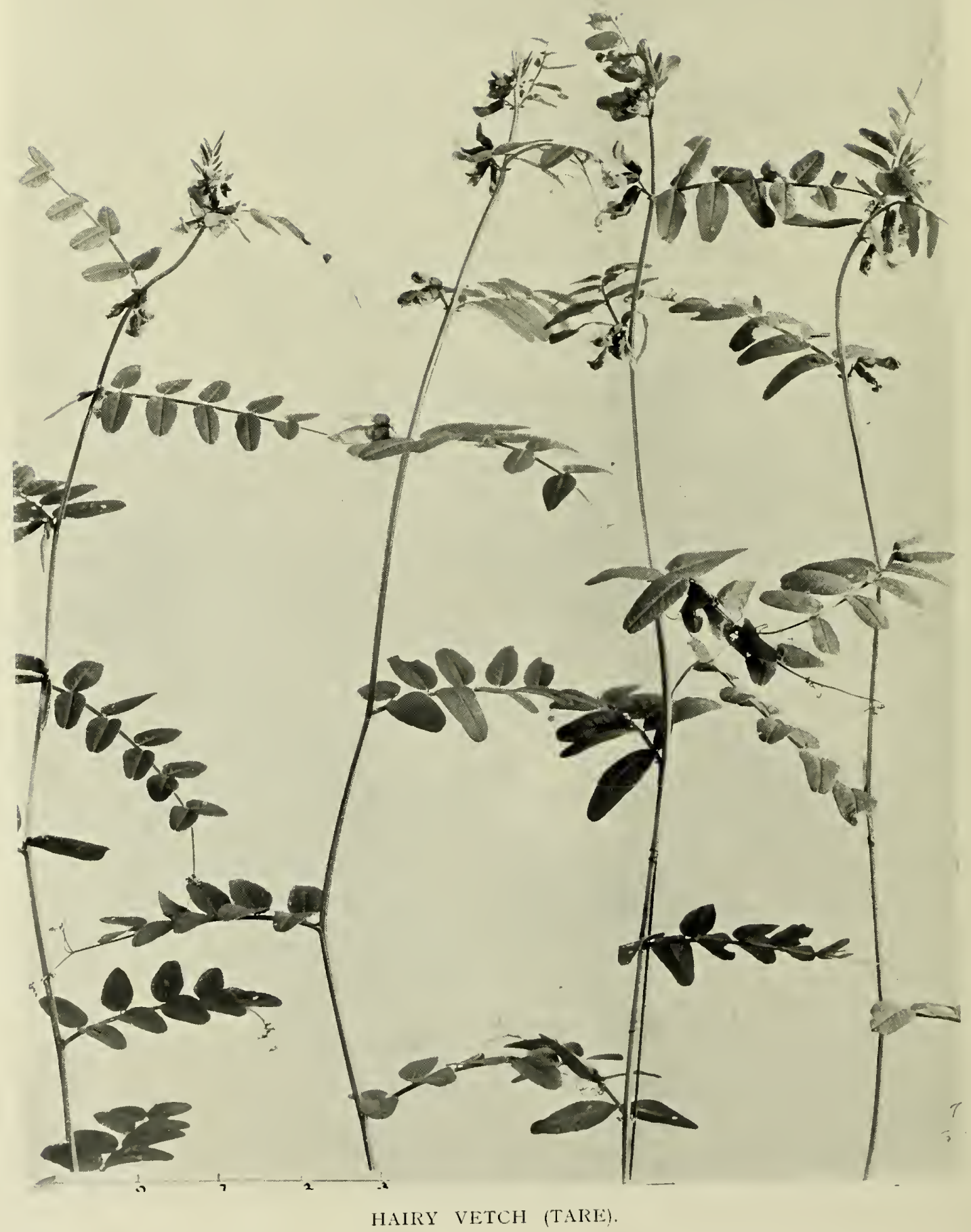




\section{HAIRY VETCH (TARE).}

Since the Vetch has been deliberately cultivated for its own sake, it is probable that the old stigma on it-as the tare of the Parable of the Sower, so finely illustrated by Millais for Dalziel's Bible-is beginning to be lost. Yet they are identical, and Parkinson describes Tares as "often found in the fields among Corne where they will, in a rainy time, quickly overspread and choke the corne, or any other herbe it groweth by." In his time "Fetches" were sometimes grown by country people "as a certaine known pulse to doves wherewith they are much delighted, and although they be wild yet where the dove houses are served herewith, they will also resort and become tame with the rest." The Vetch is a beautiful growth and flower, the arrangement of its foliage being especially attractive and useful in pattern. 


\section{7, 98. BARLEY, WHEAT AND OATS.}

The use of wheat in ornament is very old ; and in connection with its symbolism of the Blessed Sacrament has largely been employed in ecclesiastical decoration and sculpture. An instance of the latter, which may also have some punning allusion, is to be found in the Church of Fowey in Cornwall. As a device it was formerly much favoured and was adopted by the historian Philip de Comines (d. 1505) with the well-known motto Qui non laborat, non manducat. Oratio Farnese, Duke of Castro, had 4 sheaves of wheat, and the motto Flavescent-they will ripen; Pietro Francesco Tortoli, and Don Roderigo d'Avalos, Grand Constable of Castille, had a ripe ear of corn, drooping. In heraldry the garb or wheatsheaf is a common charge, and is borne by the families Grosvenor, Wauchope and Comyns among others. An old rhyme says,

\section{"Upon St. David's Day}

Put oats and barley in the clay." 


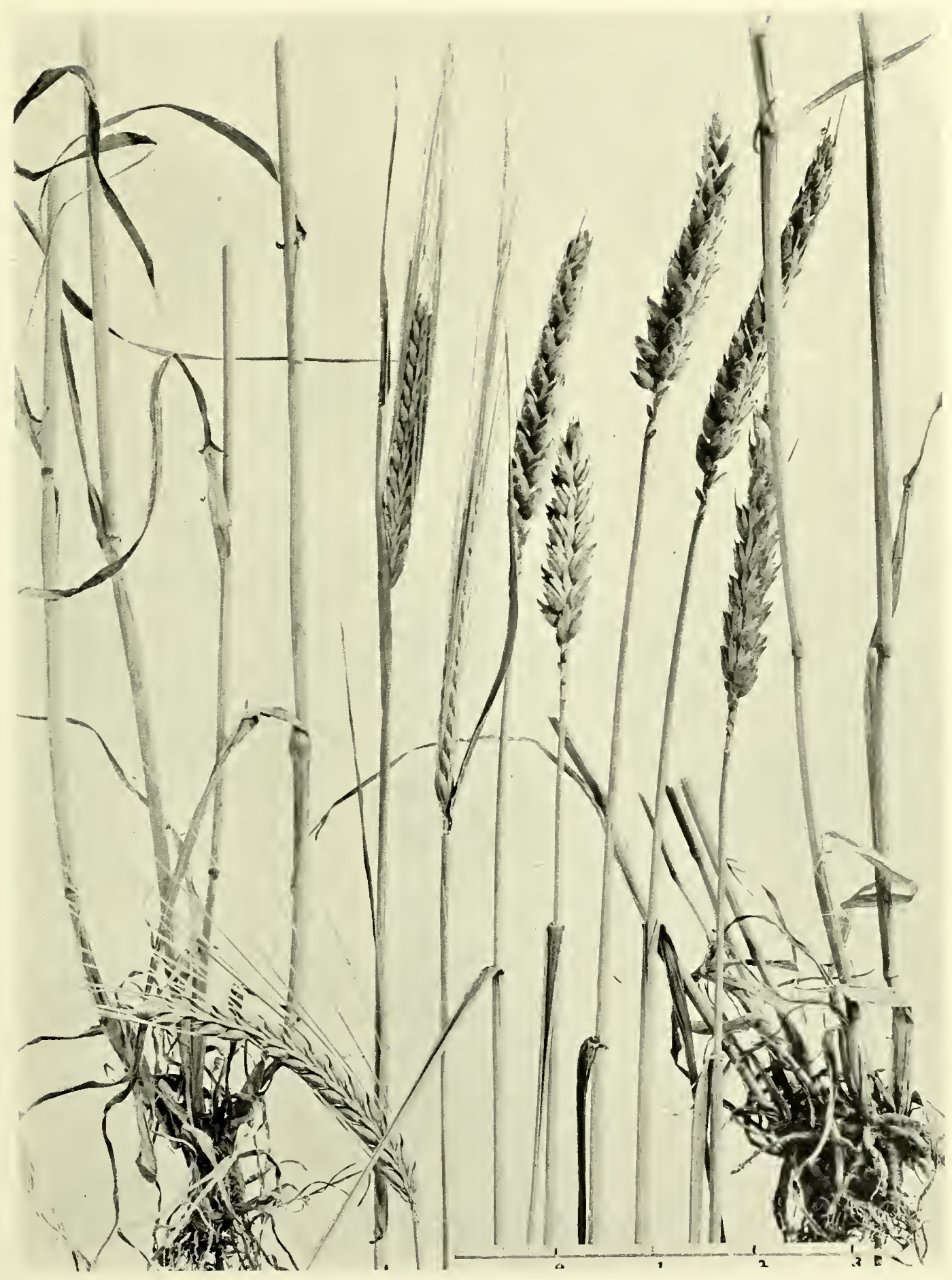

BARLEY AND IVHEAT. 



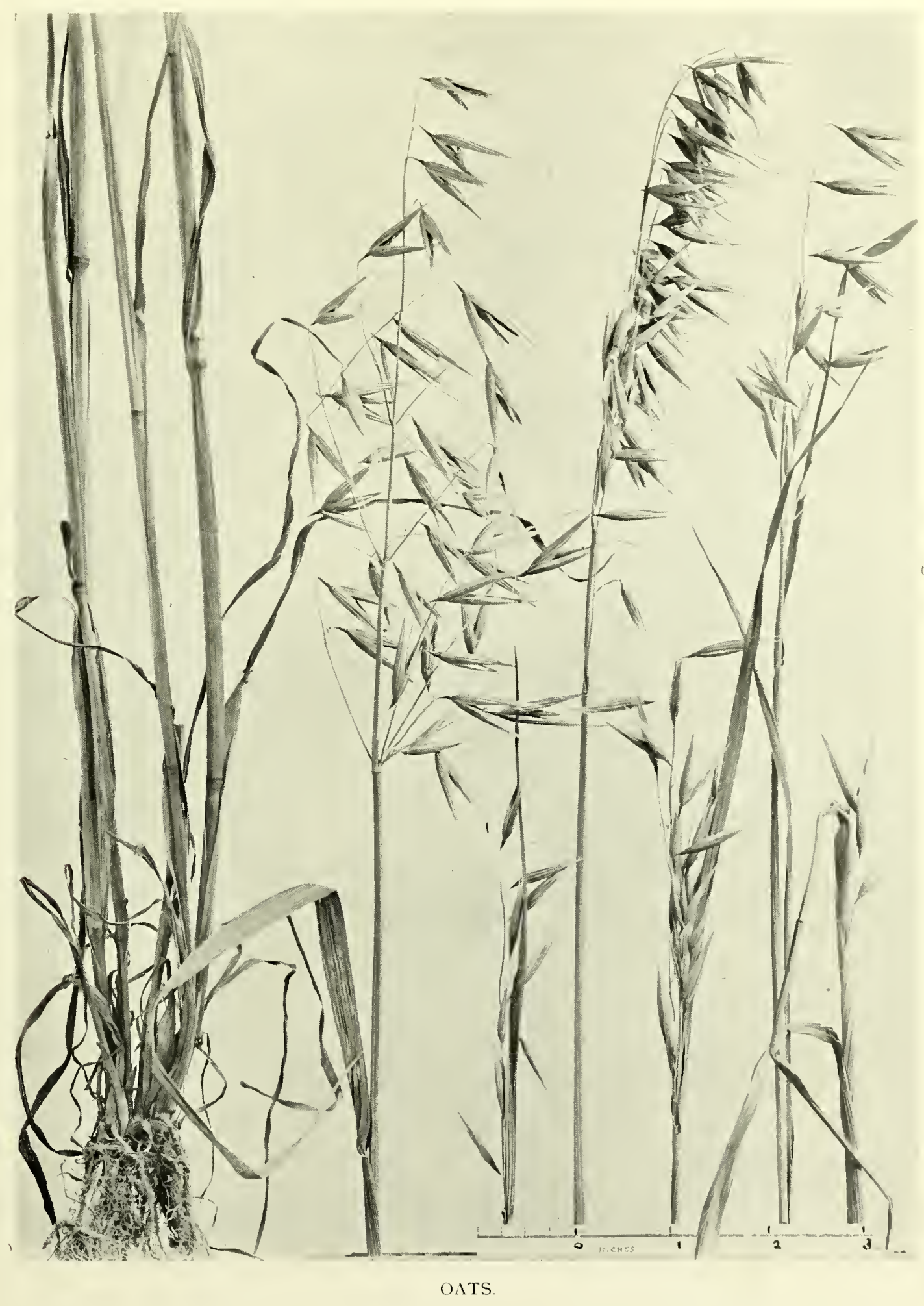





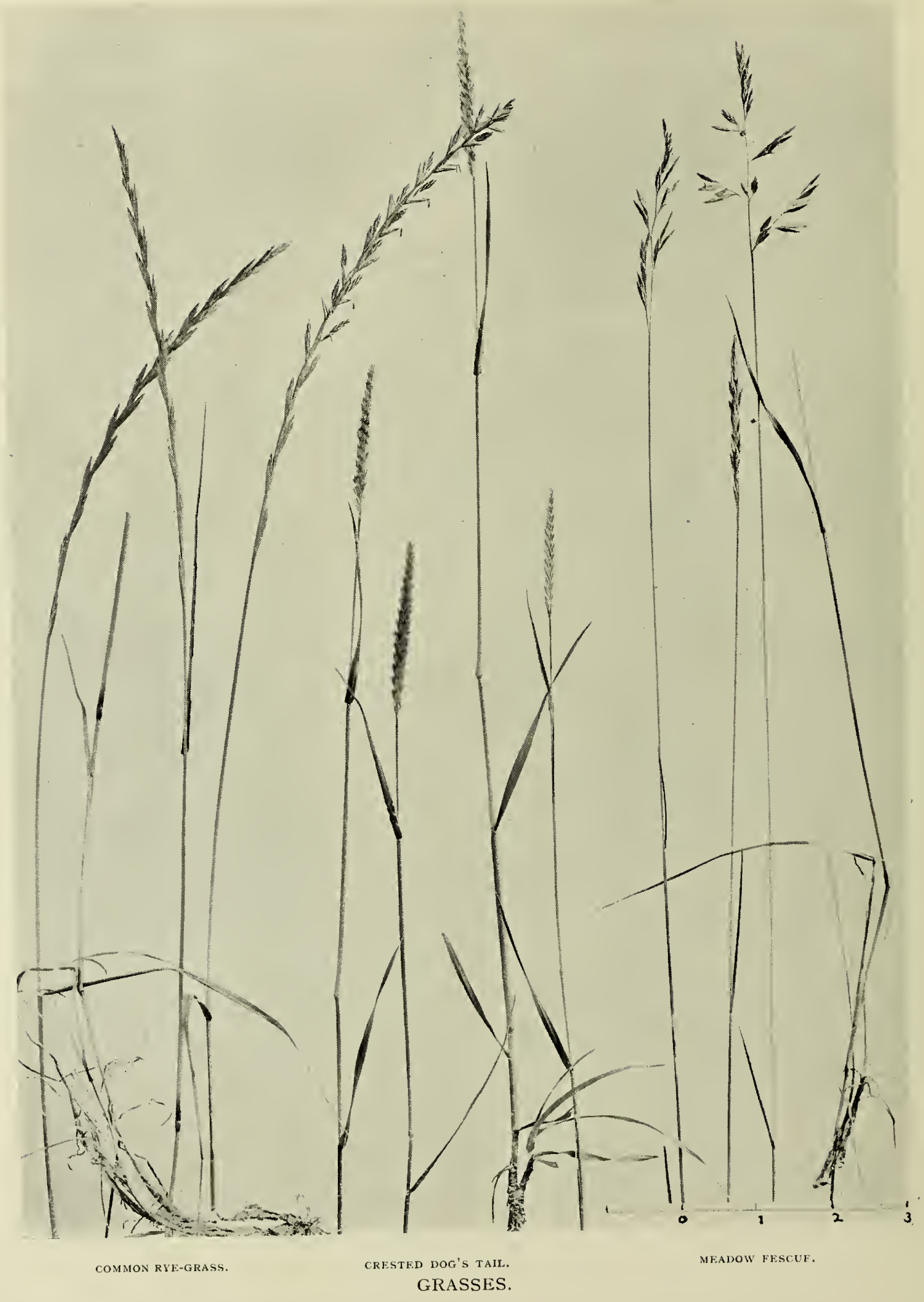





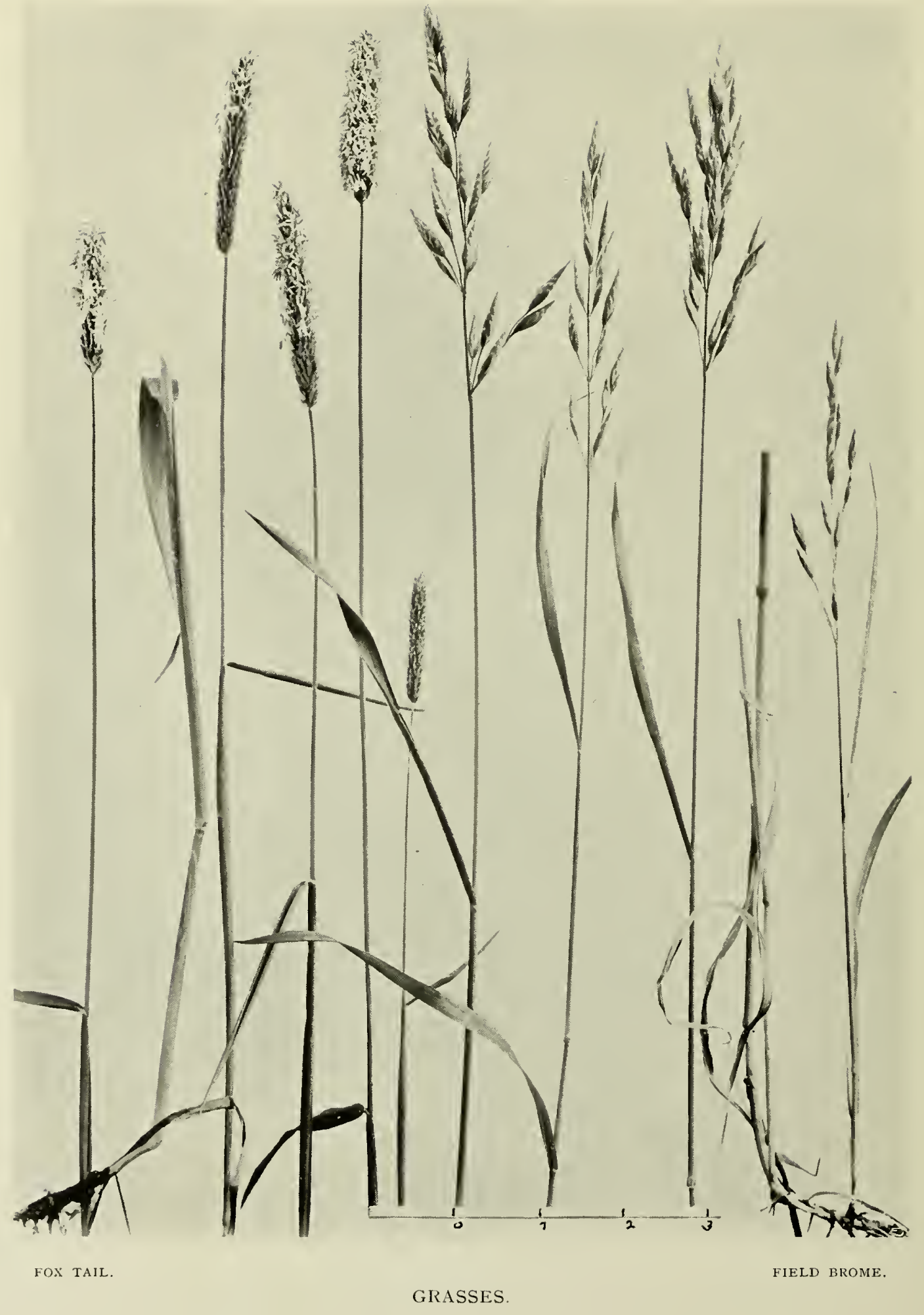





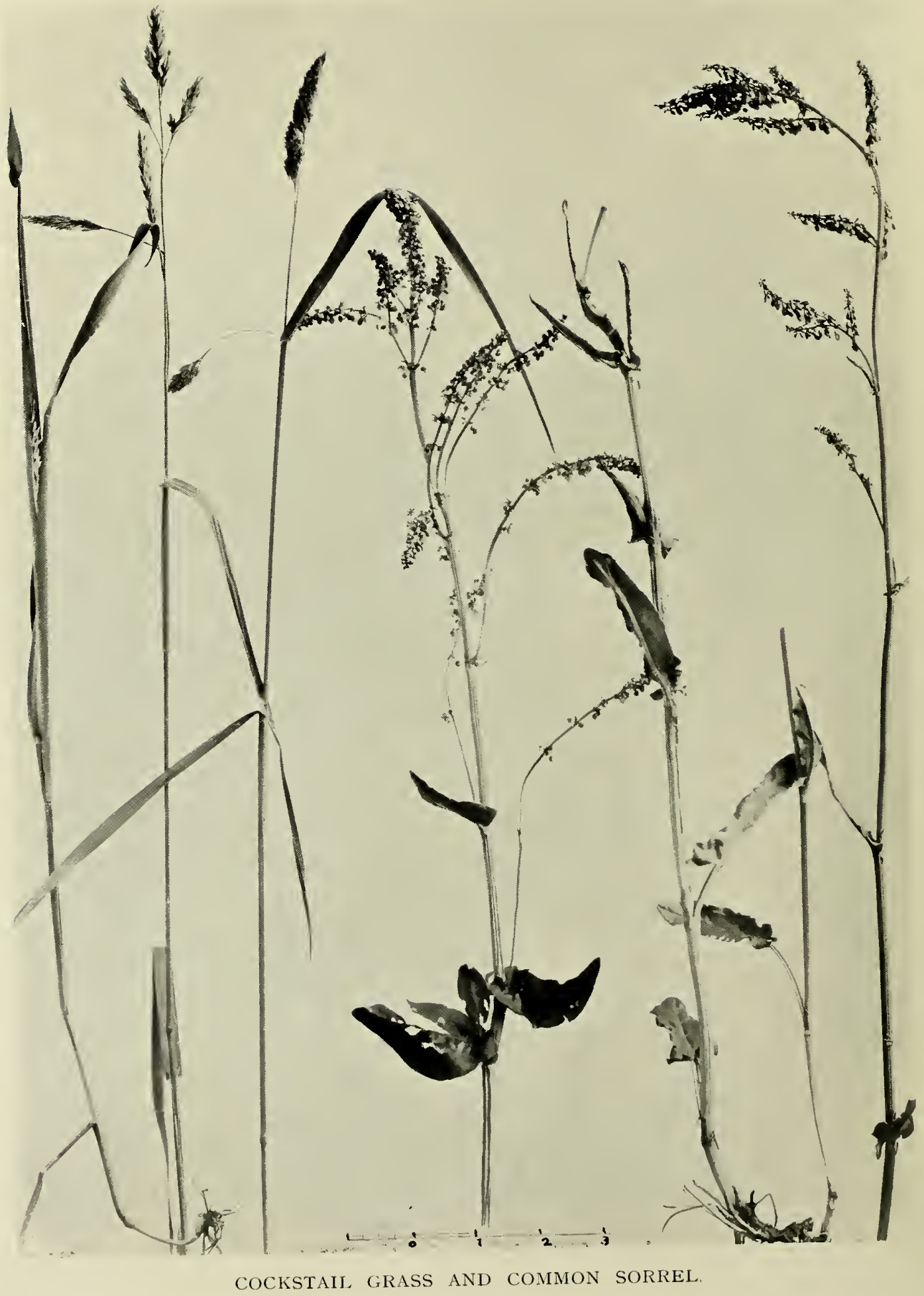


99, IOO, IOI. GRASSES AND SORREL.

Grasses, in detail, have been much neglected by students of ornament, and yet the selection now illustrated should serve to show how fruitful a source of inspiration this product of Nature may be, particularly for borders in general, and ornamental needlework and embroidery in particular. When grass is used in heraldry it is always shown in Tufts; Tylsley, for instance, has-argent, 3 tufts of grass, vert. 


\section{I02. GOATSBEARD.}

The appropriately-named Goatsbeard is also called, in some parts of the country, " Jack-go-to-bed-at-noon," from its property of folding up its bright yellow, dandelion-like flowers at that hour. On poor, high-standing land, it flourishes in great profusion; and, at a little distance, makes whole fields appear quite goldenhued. The seed is very interesting in form; and though the general growth is somewhat ragged, the beauty of this detail and of the closed buds claim our respect. 


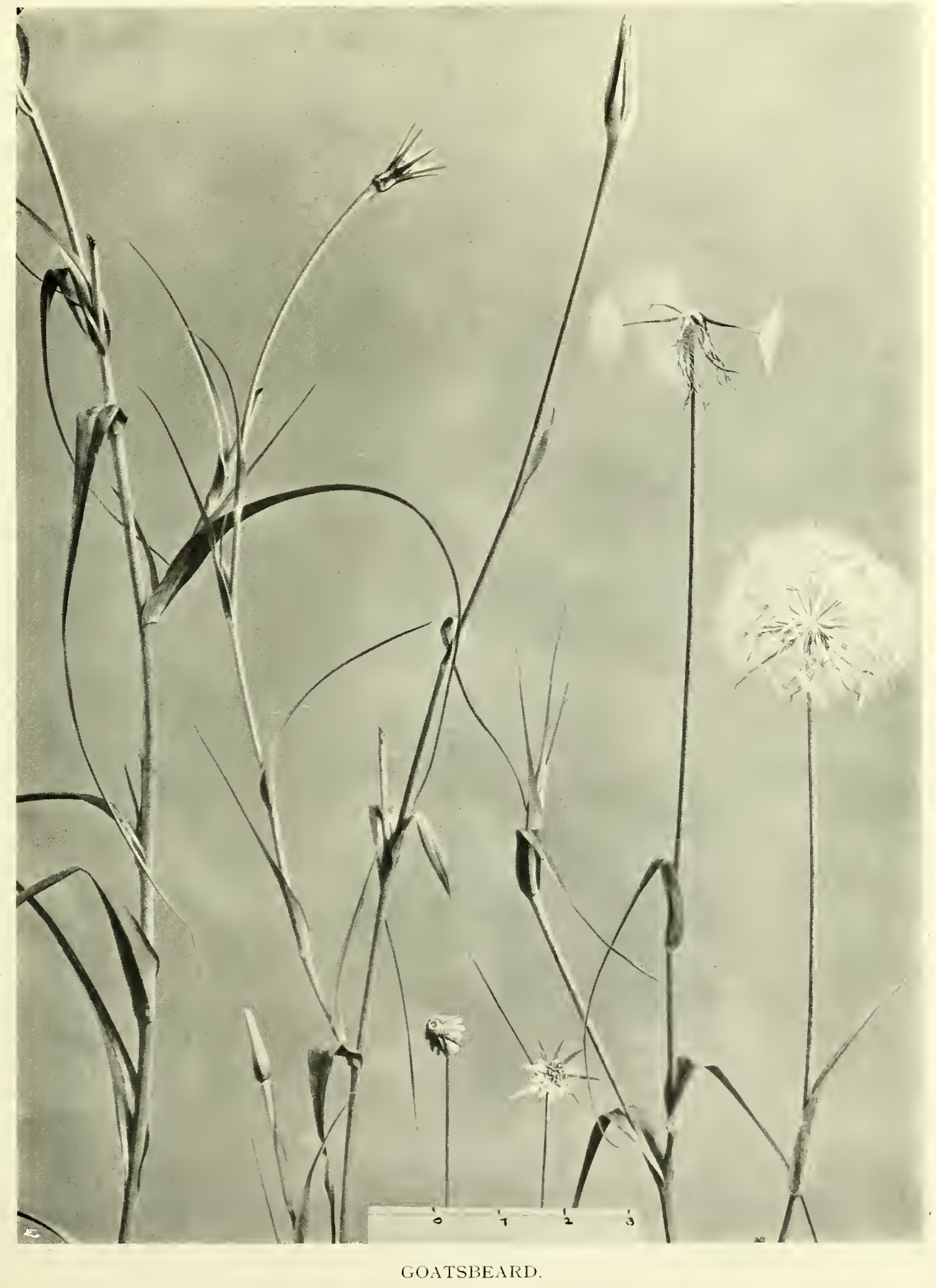






\section{I04. THISTLE.}

The Thistle is one of the best of plants for the purpose of the designer, however it may fail to appeal to the gardener and to the agriculturalist. As the national badge of Scotland, it has an assured place in ornament, and it also appears as a heraldic charge, for instance, in the arms of-Ogilvie of Kincardineshire, and of Pembroke College, Oxford, the Earl of Leven and others. It formed part of the device of the Order of Notre Dame du Chardon, instituted by Louis II., 3rd Duke of Bourbon (d. I4Io); and was also used by Count Battista da Lodrone and by Philippa, wife of René II., of Lorraine ; as well as in the famous Order of the Thistle of Scotland. One of the herbalists speaks of the "Common Thistle, whereof the greatest quantitie of down is gathered for divers purposes, as well by the poore to stop pillowes, cushions and beds for want of feathers, as also bought of the rich upholsters to mixe with the feathers and downe they do sell, which deceit would be looked into." The old writers mention many varieties of thistle, some curiously named, e.g., "Our Ladie's Thistle, St. Barnabas Thistle, Chameleon Thistle, Frier's Crowne Thistle, Melancholy Thistle and Cruel Sharpe Thistle." 


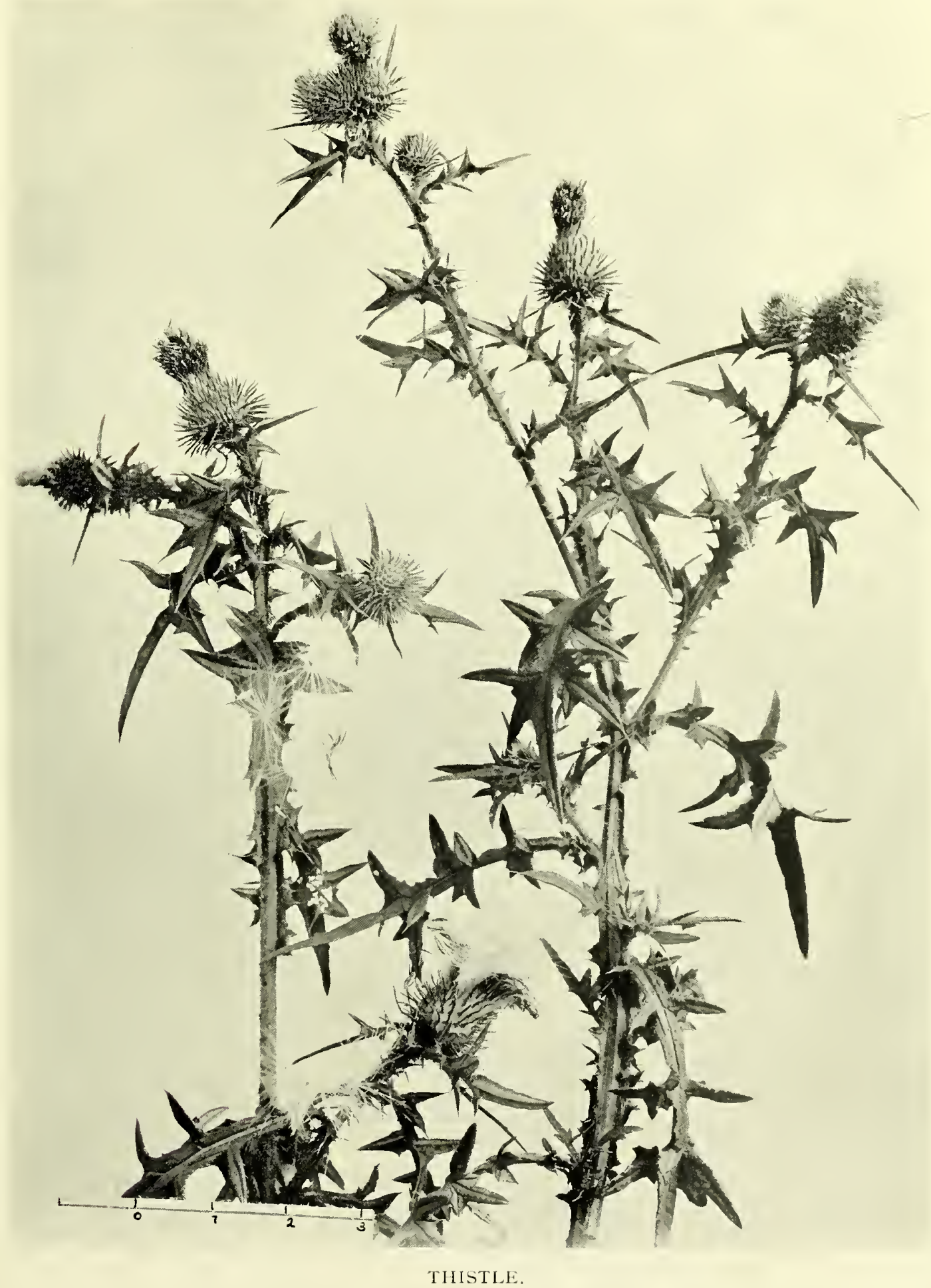



. . 


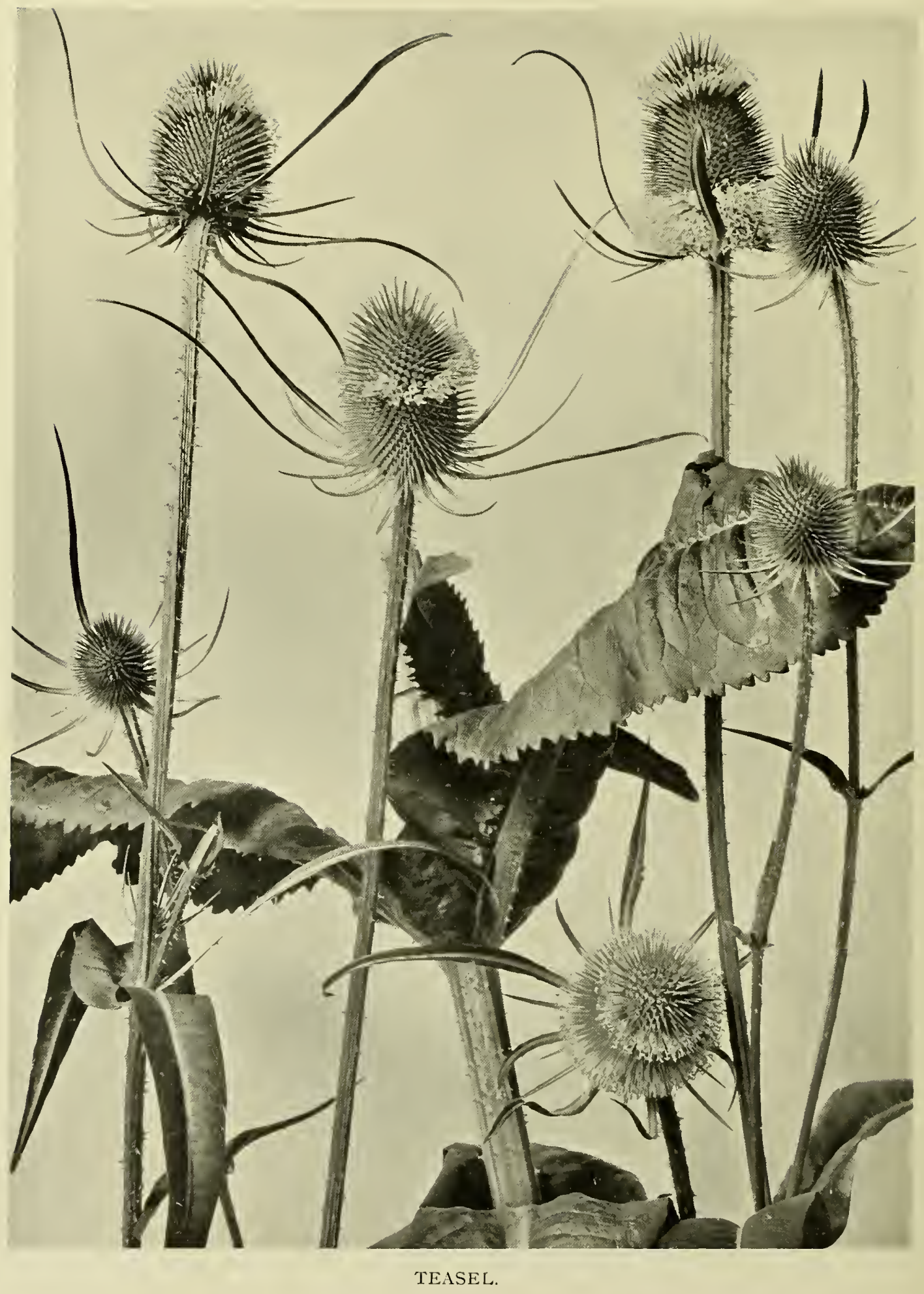


105. TEASEL.

The Teasel is a handsome plant, which has been driven out of profitable cultivation by the introduction of machinery to take its old office of dressing wool, and is not nearly so much grown in ornamental gardens as it deserves. Its beautiful and unusual blossom ought to make it useful to decorative artists, and the foliage is characteristic and full of suggestion. The Teasel appears, in heraldry, in the arms of the Clothworkers' Company, and those of the Exeter Weavers' Company. In the neighbourhood of the latter city it was once cultivated to a considerable extent. 



\section{List of Plates}

Grape Vine

.. Frontispiece

I Pear Blossom

2 Apple Fruit

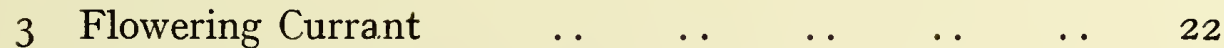

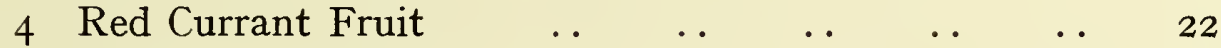

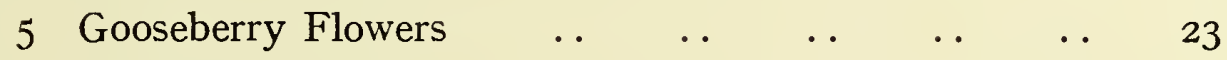

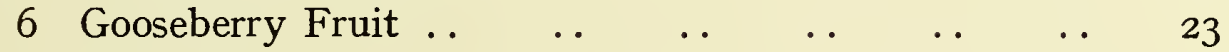

$\begin{array}{llllllllll}7 & \text { Raspberry .. } & \ldots & \ldots & \ldots & \ldots & \ldots & \ldots & 24\end{array}$

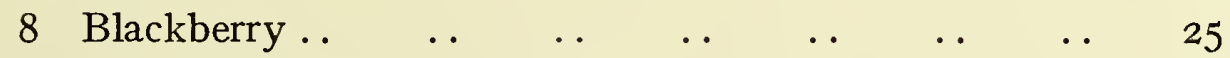

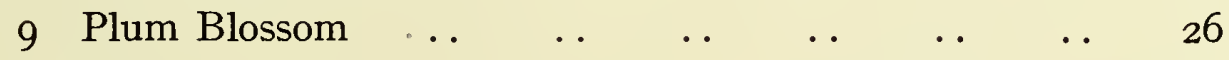

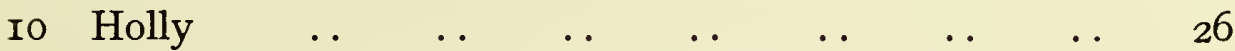

II Field Maple, Foliage and Seed Vessels $\quad \ldots \quad \ldots \quad 27$

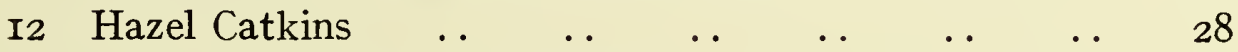

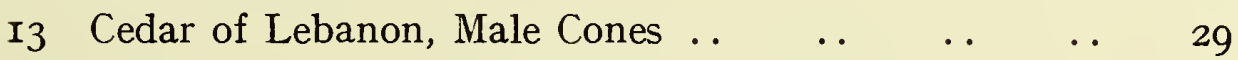

I4 Broom $\quad \ldots \quad$.

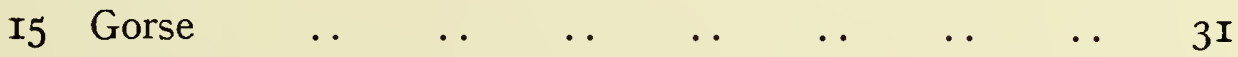

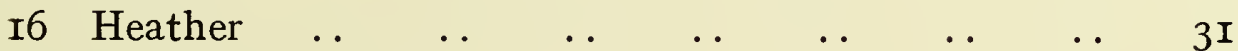

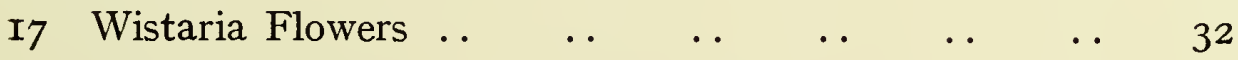

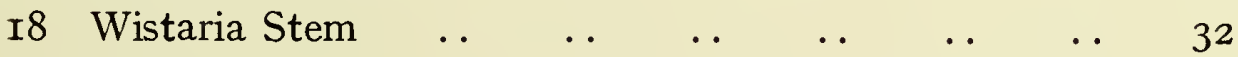

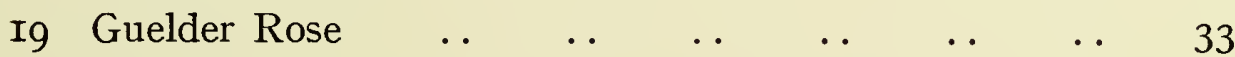

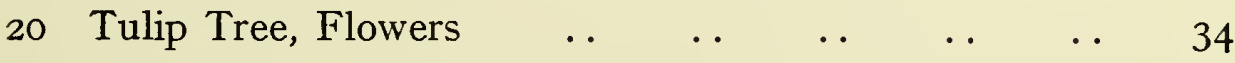

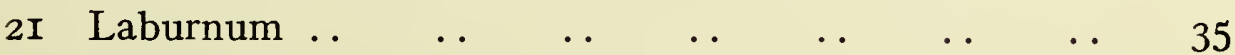

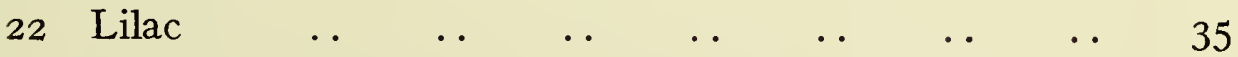

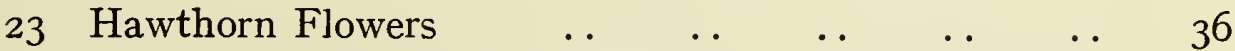

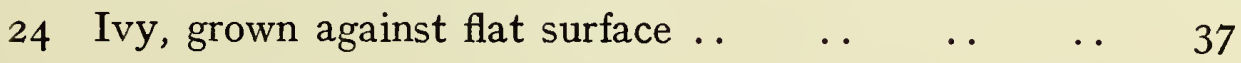

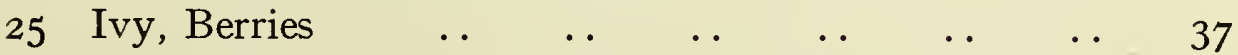

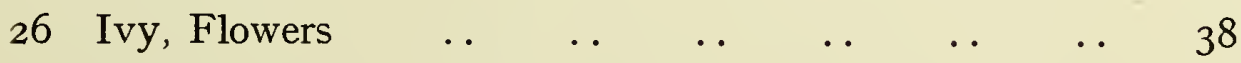

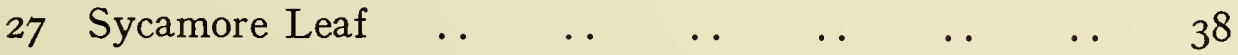

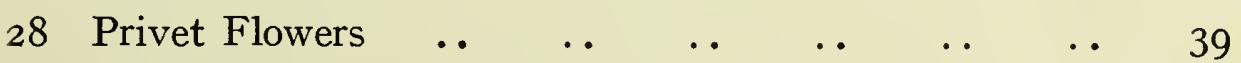

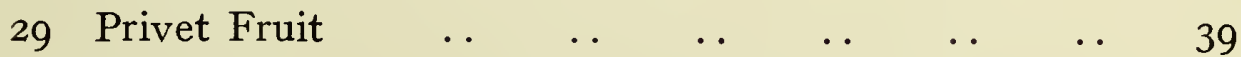

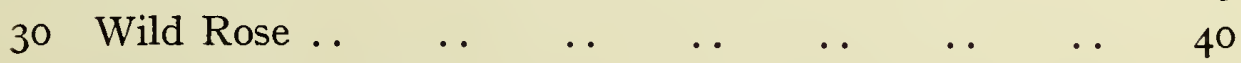

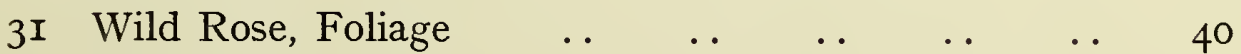

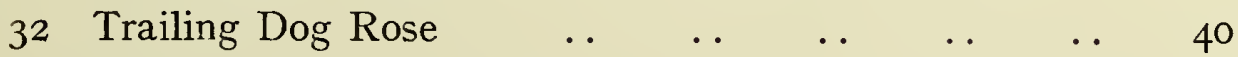

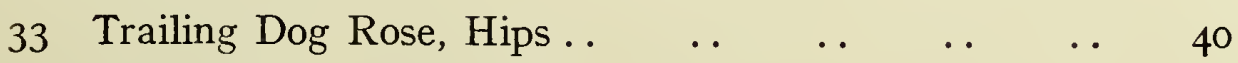

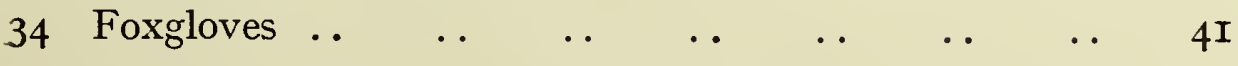


List of Plates

$\begin{array}{llllllllll}35 & \text { Lupin } & \text {. } & \text {. } & \text {. } & \text {. } & \text {.. } & \text {.. } & \text {. } & 42\end{array}$

$\begin{array}{lllllllll}36 & \text { Sweet William } & . & \ldots & \ldots & \ldots & \ldots & \ldots & 43\end{array}$

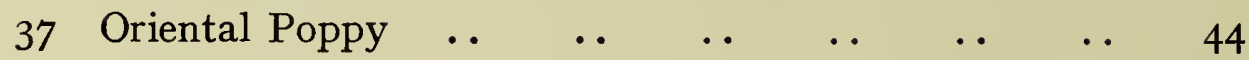

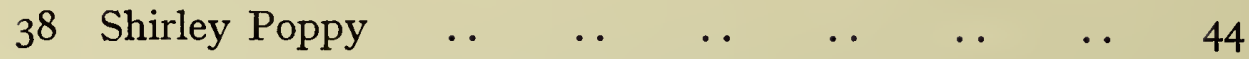

39 Seed Vessels (Poppy, Wild Hyacinth, Day Lily, Columbine) 45

$\begin{array}{llllllll}40 & \text { Canterbury Bell } & \text {.. } & \text {. } & \text {.. } & \text {.. } & \text {.. } & 45\end{array}$

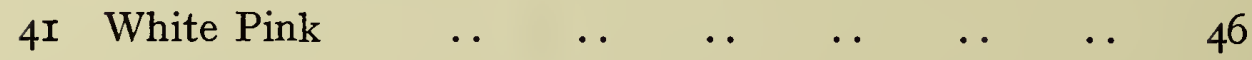

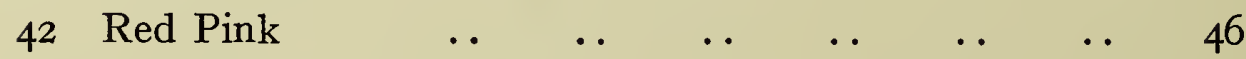

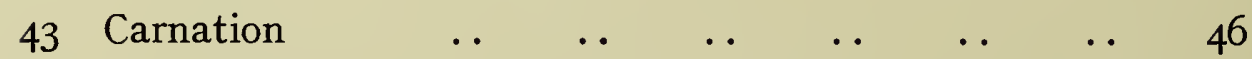

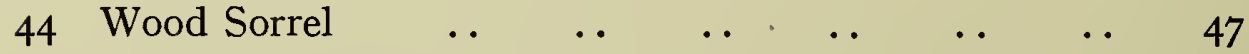

$\begin{array}{llllllll}45 & \text { Chrysanthemum } & \text {. } & \text {.. } & \text {.. } & \text {.. } & \text {.. } & 48\end{array}$

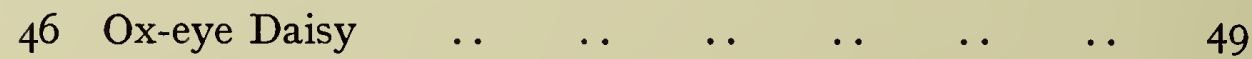

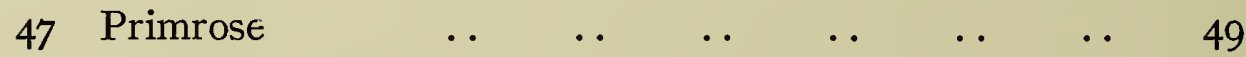

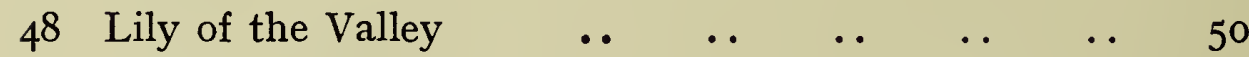

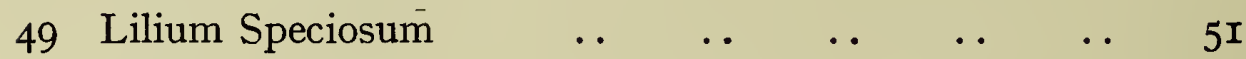

$\begin{array}{llllllll}50 & \text { Lancifolium Lily } & . . & \ldots & \ldots & \ldots & \ldots & \text { 5I }\end{array}$

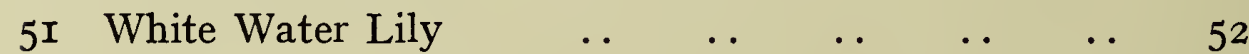

$\begin{array}{llllllllll}52 & \text { Clarkia } & . & \ldots & \ldots & \ldots & \ldots & \ldots & \ldots & 52\end{array}$

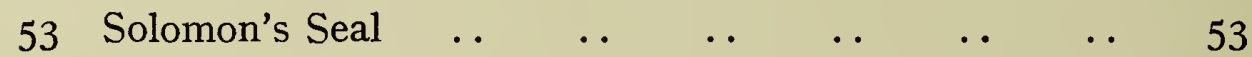

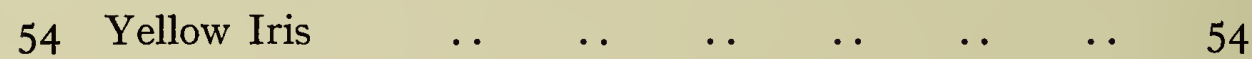

$\begin{array}{llllllllll}55 & \text { Pansy } & \text {. } & \ldots & \ldots & \ldots & \ldots & \ldots & \ldots & 55\end{array}$

$\begin{array}{llllllllll}56 & \text { Crocus } & . . & . . & . . & \ldots & \ldots & \ldots & . . & 55\end{array}$

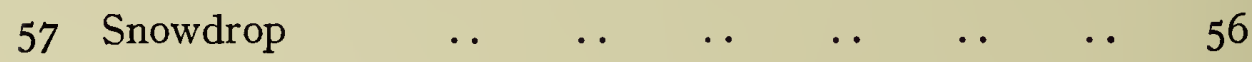

$\begin{array}{llllllllll}58 & \text { Tulip } & \text {. } & \text {. } & \ldots & \ldots & \ldots & \ldots & . . & 56\end{array}$

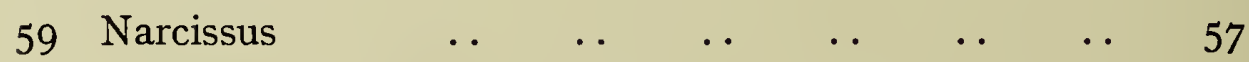

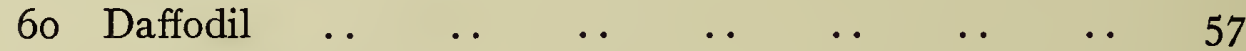

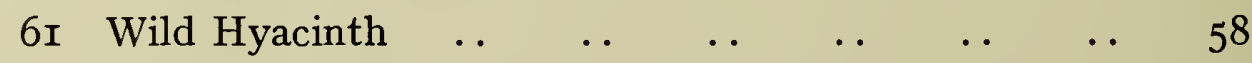

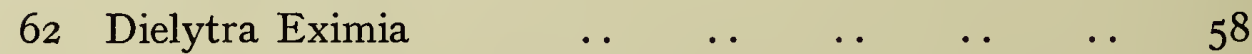

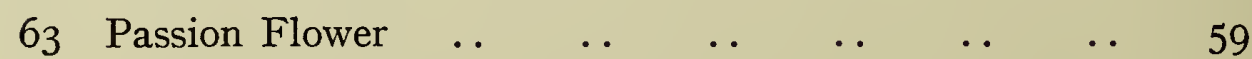

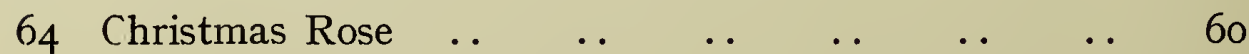

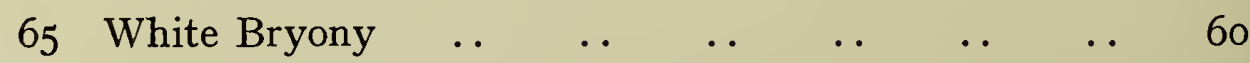

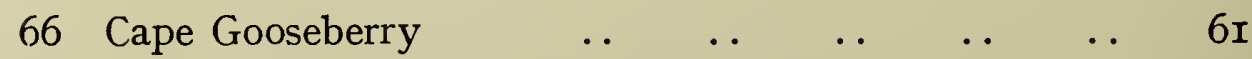

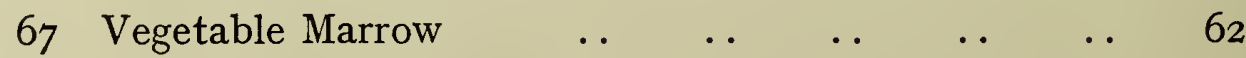

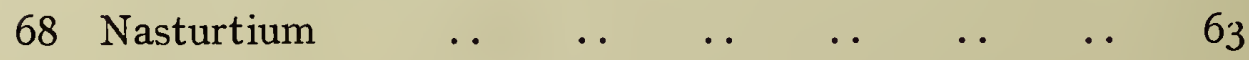

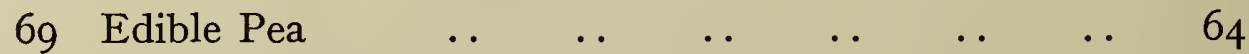

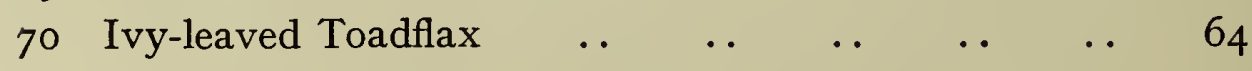




\section{List of Plates}

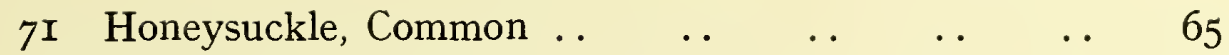

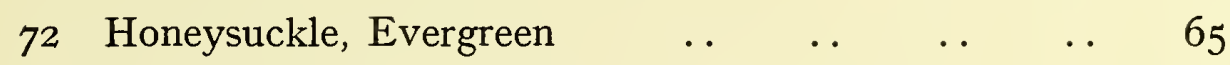

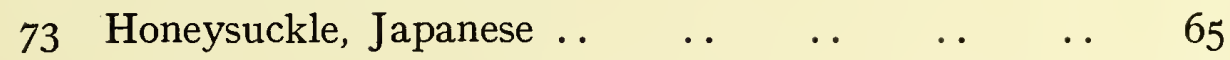

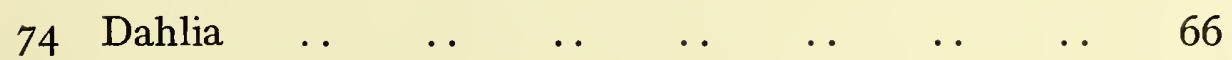

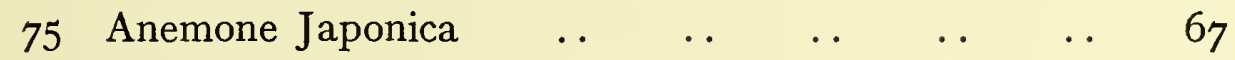

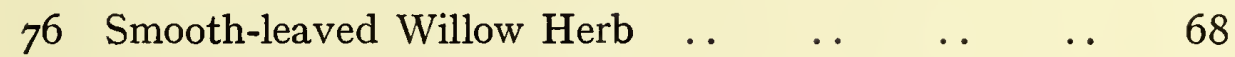

$\begin{array}{lllllllll}77 & \text { White Campion } & \ldots & \ldots & \ldots & \ldots & \ldots & \ldots & 69\end{array}$

$\begin{array}{llllllll}78 & \text { Wood Strawberry } & \ldots & \ldots & \ldots & \ldots & \ldots & 69\end{array}$

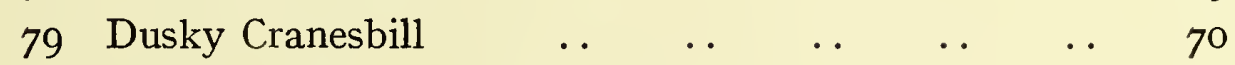

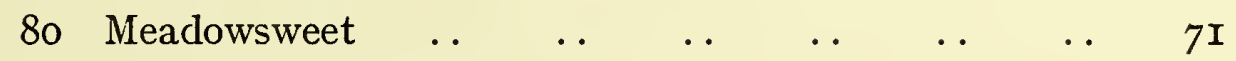

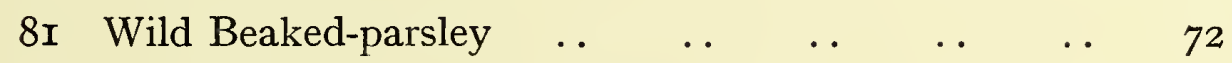

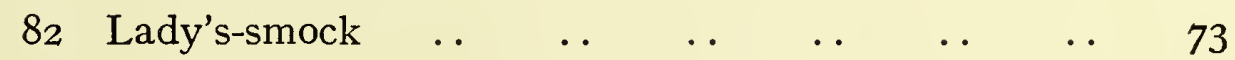

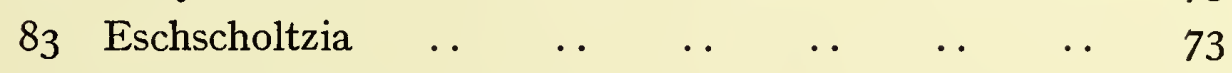

84 Love-in-a-Mist $\ldots \begin{array}{llllllll} & \ldots & \ldots & \ldots & \ldots & \ldots & 74\end{array}$

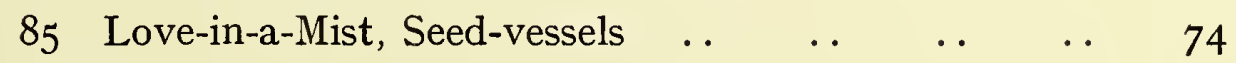

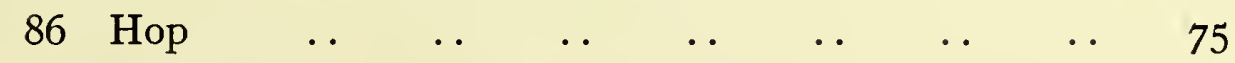

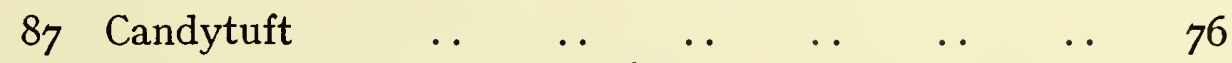

88 Common Avens (Herb Bennet) $\quad \ldots \quad \ldots \quad \ldots \quad \ldots 77$

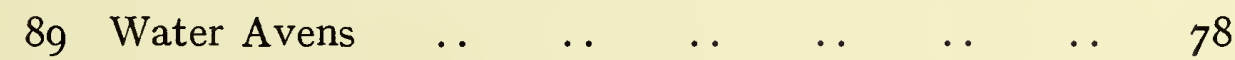

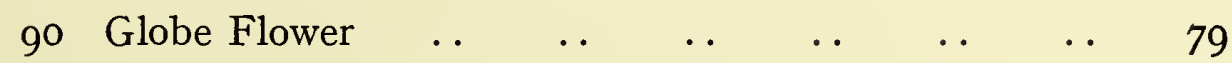

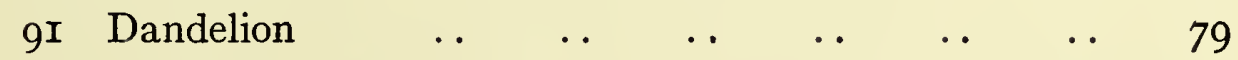

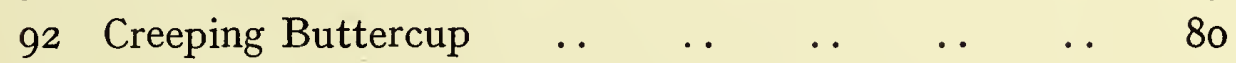

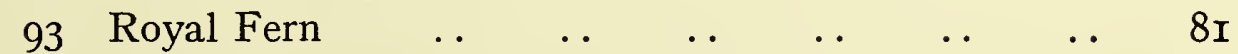

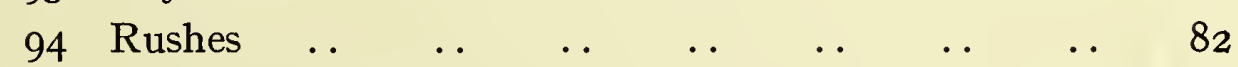

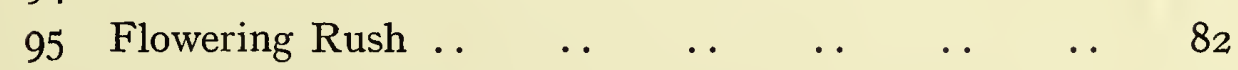

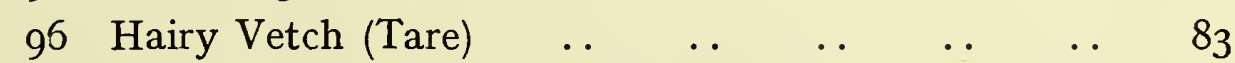

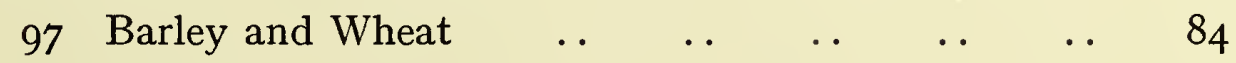

$\begin{array}{lllllllllll}98 & \text { Oats } & \ldots & \ldots & \ldots & \ldots & \ldots & \ldots & \ldots & 84\end{array}$

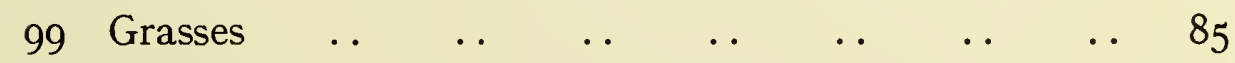

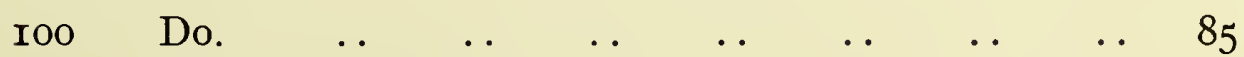

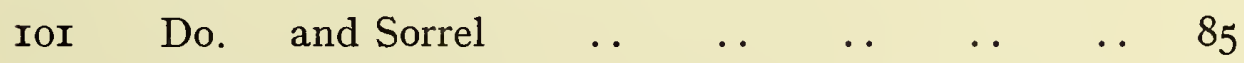

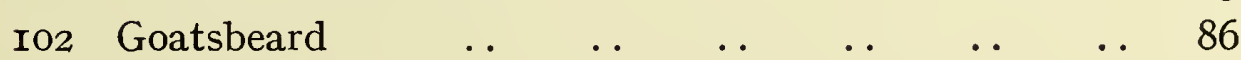

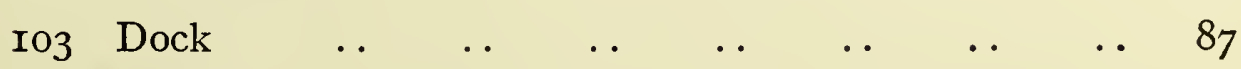

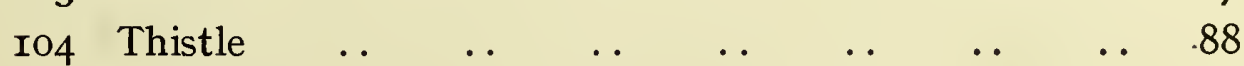

$\begin{array}{lllllllllll} & \text { ro5 Teasel } & \ldots & \ldots & \ldots & \ldots & \ldots & \ldots & \ldots & 89\end{array}$ 

Books on Plant-form and Design since 1854

NoTE.-This list does not pretend to be a complete bibliography, but to supply a list of those works, British and Foreign, which the author's experience has shown to be useful for one purpose or another.

Albert, F.-Bunte Blumen und Vögel. I892.

BEHRENS, C.-Blattformen. I899-I9oo.

Behrens, C.-Blüthe und Frucht. Ig02.

BlERY, E.-Etudes de Plantes. I864.

BlERY, E.-Etudes de Fleurs. I868.

CAPEInich, J.-Etudes de Fleurs. I885.

Capeinich, J.-Tableaux et Panneaux de Fleurs. $\mathbf{I 8 8 2 .}$

Clark, E. E.-Handbook of Plant-form. I904.

DECOR.-Le décor floral. I903.

Derby, The Arts Company.-Design and Plant-form. I903.

Derby, The Arts Company.-Drawing of Fruit and Blossom. I903.

Derby, The Arts Company.-Drawing of Foliage and Flowers. I903.

ETUdES DE Fleurs.-2 parts. I883.

Favart, E.-Flowers and Plants from Nature. I88o.

Flinzer, F.-Pflanzenblätter im Dienste. I899.

Foord, J.-Decorative Flower Studies. Igor. Second Series, Igo6.

Gerlach, M.-Die Pflanze. 4 vols. I886.

Gerlach, M.-Festons und Decorative Gruppen. 2 vols. $\quad$ I893.

GERLACH, M.-Festons und Decorative Gruppen, another series, 2 vols. 1893 .

Gerlach, M.-Blumen und Pflanzen. I896.

Grasset, E.-Plants and their Application to Ornament. I896IgOo.

GrasseT, E.-La plante et ses' applications ornamentales. 2nd Series. I900.

Grobon, F. F. and E. A.-Nouvelle collection de bouquets, fleurs et fruit, n.d.

Grobon, F. F. and E. A.-Méthode Grobon frères, études progressives de fleurs et de fruits, n.d.

Grobon, F. F. and E.A.-Groupes de fleurs et de fruits, n.d.

Habert-Dys, J.-Caprices décoratifs des fleurs. Igoo.

HAItÉ, G. C.-Plant Studies for Artists. I884.

Heath, F. G.-Autumnal Leaves. I88I. 


\section{Books on Plant-form and Design}

HULME, F. E.-A Series of Sketches from Nature of Plant-form. I868. Hulme, F. E.-Plants and their Natural Growth and Ornamental Treatment. I874.

KolB, G.-Von der Pflanze zum Ornament. I902.

KRUMBholz, K.-Das Vegetabile Ornament. I879-80.

KRUMBHOLZ, K.-Vegetabile Naturformen. I897.

LAMBERT, H.-La flore décorative. n.d.

LAMBERT, H.-Les Orchidées. I898.

Lilley, A. E. V. and W. Midgley.-A Book of Studies in Plantform. I896. Enlarged edit. I902.

Lorain, P.-La flore décorative. Series I and 2. I900.

LUTHMER, F.-Blüthenformen, etc. I893.

Magniant, M.-Fantaisies Florales. I898.

Meurer, M.-Pflanzenformen. I895.

Meurer, M.-Meurer's Pflanzenbilder. 2 vols. I897-I903.

Moser, F.-Handbuch der Pflanzenornamentik. I893.

OFFORD, G. F.-Flowers and Berries. I902.

OGawA, K.-Chrysanthemums of Japan. I893.

OGawA, K.-Lilies of Japan. I893.

OGAWA, K.-Some Japanese Flowers. I894; and another edit. Plauszewski, P.—Plantes et fleurs décoratives de plein air. I898. Plauszewski, P.-Encyclopédie florale. I899.

Ryan, H.-Rough Sketches from Nature. I880.

PiCARD, A.-L'Ornamentation fleurie. I89I.

Pilters, J.-Fantaisies florales. I899.

Pronberger, L.-Seltene Naturformen. I90I.

RHEAD, G. W.-Studies in Plant-form. I903.

SEGUY, E. A.-Les fleurs et leurs applications décoratives. I90r.

Sparkes, J. C. L.-Wild Flowers in Art and Nature. I894.

Stannus, H.-Decorative Treatment of Natural Foliage. I89I. Cantor Lecture.

StaufFacher, J.-Studies and Compositions. I887.

Storck, J. von L. Ritter.-Die Pflanze in der Kunst. 2 vols. I895-I900.

TномаS, J.-Suggestions from Bird and Flower. 1885.

Townsend, W. G. P.-Plants and Plant Studies. Igor.

Verneuil, M. P.-Etude de la Plante. Igo3.

WARD, J.-Floral Studies. IgO2.

Weimar, W.-Blumen Aufnahmen. Igor.

Winther, A.-Zweige und Ranken. I899. 





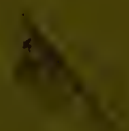

